\title{
The Automatic Reporting of Lawyer Misconduct to Disciplinary Authorities: Filling the Reporting Gap
}

\begin{abstract}
ARTHUR F. GREENBAUM ${ }^{*}$
An effective lawyer disciplinary system is essential to the protection of clients, third parties, and the profession as a whole. The present system, howeverwhich relies primarily on complaints filed by lawyers, judges, and clientsoften fails to capture misconduct, which, either standing alone or as part of a larger pattern of misconduct, warrants disciplinary attention by sanction or through remedial training.
\end{abstract}

A robust automatic reporting regime, triggered by the occurrence of identifiable acts, would help fill this reporting gap. The system I envision places reporting duties on third parties providing services to lawyers, the courts, and individual lawyers already convicted of a crime or sanctioned for unethical conduct. Some of these duties, like overdraft notification by banks or self-reporting by lawyers, are already well established, although not universally so. Others, like imposing a reporting duty on malpractice insurers or courts, have not been adopted widely. None have been systematically studied. Each of these devices has its own costs, benefits, and unintended consequences. Each can be implemented in a variety of ways. This Article catalogs and critiques those costs, benefits, and consequences, and provides recommendations for the implementation of these devices.

TABLE OF CONTENTS

I. INTRODUCTION

A. The Need for Greater Reporting of Lawyer Misconduct to Disciplinary Authorities.

1. Gaps in the Current Reporting System for Reporting Lawyer Misconduct.

2. Why the Gaps in the Current Reporting System Need to Be Closed.

B. An Additional Paradigm for Identifying Lawyer Misconduct .. 443

II. REPORTING BY ENTITIES OUTSIDE THE LEGAL PROFESSIONTRUST ACCOUNT OVERDRAFT NOTIFICATION 445

* James W. Shocknessy Professor of Law, The Ohio State University Moritz College of Law. I wish to thank T. Conrad Bower, Danielle Gadomski, Andrew Gammill, Zachery Keller, and Jillian Wolosiansky for their research assistance. Thanks also to Bruce Campbell, Jonathan Coughlan, Robert Fellmeth, Larry Garvin, Jack Sahl, and those in attendance at the Moritz College of Law Faculty Workshop, at which I presented an earlier draft of this Article, for their thoughtful comments. I also appreciate the assistance I received from numerous state officials in California, Florida, and Ohio, who helped explain the operation of their automatic reporting regimes. Finally, I wish to thank the Moritz College of Law for its financial support through its summer research grant program. 
A. Usefulness of the Information to Disciplinary Authorities ..... 446

B. Burden of Compliance on Reporting Entity and Others ......... 448

C. Potential Compliance Problems .............................................451

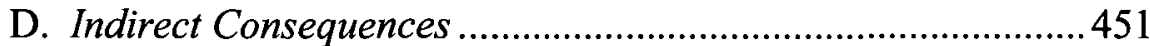

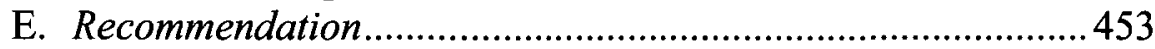

III. REPORTING BY ENTITIES OUTSIDE THE LEGAL PROFESSION-

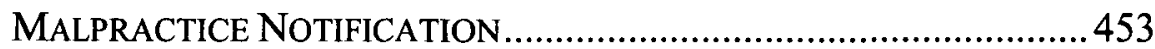

A. Usefulness of the Information to Disciplinary Authorities ..... 454

B. Burden of Compliance on Reporting Entity and Others ......... 460

C. Potential Compliance Problems ............................................. 462

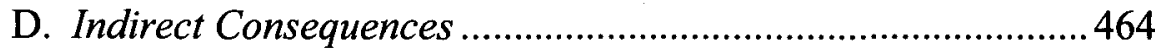

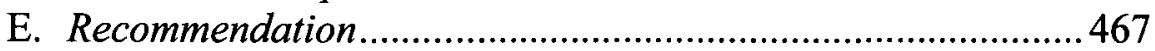

IV. REPORTING BY THOSE INVOLVED IN THE JUDICIAL PROCESS.........467 467

A. Usefulness of the Information to Disciplinary Authorities ..... 471

B. Burden of Compliance on Reporting Entity and Others ......... 473

C. Potential Compliance Problems ..............................................474

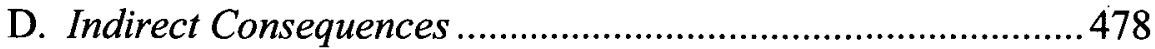

E. Modifications to the Court Reporting Requirements ...............481

F. Recommendation.....................................................................484

V. LAWYER SELF-REPORTING OF PARTICULAR EVENTS ......................486

A. Usefulness of the Information to Disciplinary Authorities ..... 491

B. Burden of Compliance on Reporting Entity and Others ..........494

C. Potential Compliance Problems ..............................................495

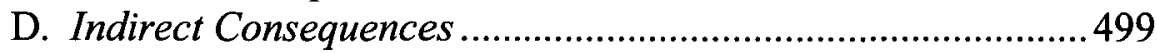

E. Extending the Self-Reporting Regime to Other Areas .............500

F. Recommendation ................................................................501

VI. Potential Systemic Problems Flowing from aN AUTOMATIC REPORTING REGIME .............................................502

A. Information and the Overzealous Disciplinary Counsel .........502

B. Automatic Reporting and System Overload............................503

C. Automatic Reporting and Resource Constraints ....................504

VII. CONCLUSION...............................................................................506 


\section{INTRODUCTION}

\section{A. The Need for Greater Reporting of Lawyer Misconduct to Disciplinary Authorities}

\section{Gaps in the Current Reporting System for Reporting Lawyer Misconduct}

It is commonly accepted that a substantial amount of lawyer misconduct goes unreported to disciplinary authorities. That reporting gap has serious implications. It undercuts the integrity of the legal profession. ${ }^{1}$ It compromises the lawyer disciplinary process, which can function only if potential misconduct comes to the attention of disciplinary authorities. ${ }^{2}$ It undermines the profession's right of self-regulation, which carries with it the responsibility to exercise sufficient oversight of lawyer conduct through an effective disciplinary system. ${ }^{3}$ There are several reasons behind this underreporting phenomenon.

The first is a general reluctance to report by those who, by virtue of their training and interactions, are most likely to witness and recognize lawyer misconduct-lawyers and judges. ${ }^{4}$ While lawyers and judges have an ethical duty to report lawyer misconduct, that duty often is ignored. ${ }^{5}$ Most

${ }^{1}$ See, e.g., MODEL CODE OF PROF'L RESPONSIBILITY EC 1-4 (1980) (“The integrity of the profession can be maintained only if conduct of lawyers in violation of the Disciplinary Rules is brought to the attention of the proper officials.").

${ }^{2}$ Cf. STANDARDS FOR IMPOSING LAWYER SANCTIONS preface (1992), available at http://www.americanbar.org/content/dam/aba/migrated/cpr/regulation/standards_sanctions.a uthcheckdam.pdf ("Only if all lawyer misconduct is in fact reported to the appropriate disciplinary agency can the legal profession have confidence that consistent sanctions are imposed for similar misconduct.").

${ }^{3}$ MODEL RULES OF PROF'L CONDUCT pmbl., qף 10-12 (2009). Although the term "selfregulation" is often used to describe the lawyer regulatory system, in reality it is a system of judicial regulation, in which lawyers and the organized bar often play a significant role. See Judith L. Maute, Bar Associations, Self-Regulation and Consumer Protection: Whither Thou Goest?, 2008 J. Prof. LAW. 53, 58. Thus the judiciary, with close ties to the legal community, rather than the legislative or executive branches, has primary, and in some states exclusive, authority over attorney regulation. See RESTATEMENT (THIRD) OF THE LAW GOVERNING LAWYERS $\S 1 \mathrm{cmt}$. c (2000) (noting that in most states the courts have the inherent power to regulate lawyers and that in many states that power is exclusive).

${ }^{4}$ I have explored this issue at length in two previous articles. One addresses reporting requirements for lawyers. See Arthur F. Greenbaum, The Attorney's Duty to Report Professional Misconduct: A Roadmap for Reform, 16 Geo. J. LegAl ETHICS 259 (2003) [hereinafter Greenbaum, Attorney's Duty to Report]. The other addresses reporting requirements for judges. See Arthur F. Greenbaum, Judicial Reporting of Lawyer Misconduct, 77 UMKC L. REV. 537 (2009) [hereinafter Greenbaum, Judicial Reporting].

${ }^{5}$ As to underreporting by lawyers, see ChARLES W. WOLfRAM, MODERN LEGAL ETHICS $\S 12.10 .1$, at 683 (1986) ("Probably no other professional requirement is as widely ignored by lawyers subject to it."). See also Lonnie T. Brown, Jr., Ending Illegitimate Advocacy: Reinvigorating Rule 11 Through Enhancement of the Ethical Duty to Report, 62 
commentators attribute this to several factors. The first is a societal attitude toward reporting the misconduct of others-we live in an anti-snitch culture. ${ }^{6}$ This is reinforced by the potential negative ramifications of reporting, including soured professional relations and possible retaliatory actions. ${ }^{7}$ While some reporting is mandatory in most systems for both judges and lawyers, the standards imposing the reporting duty are themselves filled with discretionary calls which may, as a practical matter, obviate the requirement to report. ${ }^{8}$ Given a general reluctance to report, as well as the costs associated with reporting, these flexible standards are a recipe for silence in many instances. ${ }^{9}$

This reporting gap is filled somewhat by reports by clients. In fact, this is by far the largest category of complaints disciplinary authorities receive. ${ }^{10}$ Where clear and obvious misconduct occurred, these reports can be quite valuable. Beyond those instances, however, clients often lack the background to be able to assess the propriety of lawyer conduct and thus do not know there is misconduct to report. ${ }^{11}$ Dissatisfied clients often turn to the disciplinary system with their complaints, but those complaints usually do not rise to the level of a

OHIO ST. L.J. 1555, 1599, 1600 (2001) (noting with respect to the ABA model reporting rules that "[t]he norm under DR 1-103(A) appears to have been non-reporting" and that "little has changed with the advent of Model Rule 8.3"); Geoffrey C. Hazard, Jr. \& Dana A. Remus, Advocacy Revalued, 159 U. PA. L. REV. 751, 774 (2011) (noting that "[1]awyers rarely report each others' misconduct" and "[j] udges are similarly reluctant"). But cf. Greenbaum, Attorney's Duty to Report, supra note 4, at 271-75 (suggesting that the data on lawyer reporting are too slim to reach a definitive conclusion on the degree of underreporting that takes place). As to underreporting by judges, see Greenbaum, Judicial Reporting, supra note 4, at 539-41.

${ }^{6}$ See, e.g., Greenbaum, Attorney's Duty to Report, supra note 4, at 269 n.46; Greenbaum, Judicial Reporting, supra note 4, at 545.

${ }^{7}$ See, e.g., Greenbaum, Attorney's Duty to Report, supra note 4, at 270-71, 300, 32226; Greenbaum, Judicial Reporting, supra note 4, at 545.

${ }^{8}$ See, e.g., Brown, supra note 5, at 1600-03 (noting that the ambiguities in the model rule governing lawyer reporting and its reporting exemptions lead to a situation in which "a large segment of reportable offenses likely go unreported with the textual blessing of Model Rule 8.3"); Peter A. Joy, The Relationship Between Civil Rule 11 and Lawyer Discipline: An Empirical Analysis Suggesting Institutional Choices in the Regulation of Lawyers, 37 LoY. L.A. L. REV. 765, 806 (2004) (reviewing the language of the ethics rules requiring reporting and concluding that " $[t]$ he numerous qualifications and hurdles necessary before a lawyer or a judge has a mandatory duty to report professional misconduct implicated in Rule 11 sanctions essentially means that for most lawyers and judges there is no mandatory duty to report"); see also Greenbaum, Attorney's Duty to Report, supra note 4, at 279-82; Greenbaum, Judicial Reporting, supra note 4, at 567-68.

${ }^{9}$ See generally supra note 4 .

${ }^{10}$ See, e.g., Jack A. Guttenberg, The Ohio Attorney Disciplinary Process-1982 to 1991: An Empirical Study, Critique, and Recommendations for Change, 62 U. CIN. L. REV. 947,965 (1994) (noting that clients file "the vast majority of grievances").

${ }^{11}$ See, e.g., Deborah L. RhODE \& GeOFfrey C. HAZARD, JR., Professional RESPONSIBILITY AND REGULATION 264 (2d ed. 2007) (noting that "[u]nsophisticated individual clients... often have little way of knowing whether they are victims of incompetence, overcharging, or other disciplinary violations"). 
disciplinary infraction. ${ }^{12}$ As the California State Bar Discipline Monitor noted after more than four years of intimate study of reporting in California, "Not only are serious abuses likely to be missed where the regulatory agency relies primarily upon vocal complaints [by consumers], but at the same time many of the most vociferous complaints lack merit, or at least lack the merit indicated by the fervor of their advocacy." 13 In short, even with client complaints, a significant reporting gap remains.

A final problem with the present reporting system is that lawyer conduct often is seen in isolation. Any particular actor, whether it be a judge, lawyer, client, or third party, witnesses only a limited amount of another lawyer's behavior. To the extent a lawyer engages in a number of small missteps that standing alone would not warrant discipline, but in the aggregate might, this "pattern" evidence is often lost. ${ }^{14}$ Pattern evidence can also influence the level of sanction sought by disciplinary officials. ${ }^{15}$

12 See Guttenberg, supra note 10, at 964-65 (noting that during the period studied "clients filed most of the grievances" and that "approximately two-thirds of all grievances were dismissed on intake or shortly thereafter"); Mary Robinson, Avoiding ARDC Anxiety: A Disciplinary Primer, 84 ILL. B.J. 452, 453-54 (1996) (discussing categories of complaints, often filed by clients, which are summarily dismissed). Of course some client complaints, while raising issues that are not in and of themselves actionable, may include facts that nevertheless warrant investigation.

13 Robert C. FELLMETh, Final Report of the State Bar Discipline Monitor 40 (1991), available at http://www.cpil.org/download/Bar_Monitor_Final_Report.pdf.

${ }^{14}$ California, for example, has an extensive automatic reporting regime. At least one principle behind it is to create a cumulative record concerning a lawyer's behavior. See id. at 58-66 (describing the use of this reporting for pattern detection). In reviewing the implementation of this pattern-recognition process in his role as State Bar Discipline Monitor, Professor Fellmeth noted that patterns of misconduct arose in a significant number of cases and provided context to "seemingly marginal incoming complaint[s]." $I d$. at 66 . He concluded that " $[t]$ he import of detecting patterns is becoming increasingly apparent to those working with the system." Id; see also CAL. COMM'N ON THE FAIR ADMIN. OF JUSTICE, FINAL REPORT 71, 73, 74 (Gerald Velman \& Chris Boscia eds., 2008) [hereinafter CCFAJ REPORT], available at http://www.ccfaj.org/documents/CCFAJFinalReport.pdf. In the portion of the report focusing on prosecutorial misconduct, the Commission noted: "Analysis of California cases in which a court made a finding of prosecutorial misconduct suggests that the phenomenon of repeat offenders is significant." Id. at 74; $c f$. Leslie C. Levin, The Case for Less Secrecy in Lawyer Discipline, 20 GEO. J. LEGAL ETHICs 1,3 (2007) (pointing to a lack of information on the extent to which lawyers receiving disciplinary sanctions are likely to become repeat offenders, but noting that the limited data available suggest "the rate of recidivism among lawyers who receive public sanctions is fairly high"). This pattern of behavior would be captured by a well-functioning automatic reporting system but might otherwise be overlooked by disciplinary authorities. Problems may arise if states impose time limits for the resolution of complaints against lawyers. The system must retain the core information from closed complaints for a reasonably extended period of time for patterns to emerge. A related concern arises where individual complaints are closed because they are deemed insufficient to warrant disciplinary action standing alone, but might warrant such action if other misconduct were also present. A mechanism must be in place to either allow cases to remain open for an extended time or to allow them to be reopened in the face 


\section{Why the Gaps in the Current Reporting System Need to Be Closed}

Having said this, it must also be acknowledged that no system is perfect. No regulatory scheme has perfect information. Why does it make sense to try to close the reporting gap? Two principal reasons emerge. ${ }^{16}$

First and foremost, lawyer misconduct harms clients, third parties, and the profession as a whole. ${ }^{17}$ When a lawyer neglects a client's matter or handles it without the requisite competence, the client suffers. When lawyers engage in abusive and improper trial practices, third parties may suffer. When lawyers fail to live up to their professional standards, the public loses respect for lawyers and the legal system, and the profession suffers. This is exacerbated to the extent the public believes the lawyer regulatory system turns a blind eye to lawyer misconduct.

Second, our disciplinary system has, for too long, focused principally on disciplining lawyers after substantial misconduct has occurred. If the system could better identify patterns of behavior that warrant intervention before serious misconduct occurs, and offer remedial training to help solve incipient problems, that would significantly benefit lawyers, clients, and the profession. ${ }^{18}$

of subsequent complaints against the lawyer. $C f$. OHIO STATE BAR ASS'N, REPORT OF THE COMMITTEE TO REVIEW OHIO's DisciplinARY PROCESS 39-40 (1997) (discussing Recommendation 22, which advocates adoption of a rule that would allow grievances that are colorable, although insufficient to prosecute on their own, to be held open for a period of time in case additional misconduct comes to light, rather than be dismissed).

15 See, e.g., STANDARDS FOR IMPOSING LAWYER SANCTIONS $\S 9.22$ (c)-(d) (1992) (treating a pattern of misconduct and multiple offenses as aggravating circumstances in deciding on the level of discipline to impose). For an example of a case applying these standards, see In re Obert, 89 P.3d 1173, 1180 (Or. 2004).

${ }^{16}$ Less compelling, but also of concern to some, is the fear that if self-regulation is perceived as failing, calls for outside regulation will increase. See Maute, supra note 3, at 65 ("Repeatedly, when major scandals erupt involving the use of legal services the resulting public outcry prompts calls for external regulation."). See generally William T. Gallagher, Ideologies of Professionalism and the Politics of Self-Regulation in the California State Bar, 22 PEPP. L. REv. 485 (1995) (providing a detailed account of the impact of such factors on the evolution of the unique disciplinary process in California).

${ }^{17}$ Protecting clients, third parties, and the profession as a whole are the core concerns of the lawyer disciplinary system. See Greenbaum, Attorney's Duty to Report, supra note 4, at 264; see also STANDARDS FOR IMPOSING LAWYER SANCTIONS $§ 1.1$.

${ }^{18}$ This idea has been endorsed by the American Bar Association (ABA). See ModEL RULES FOR LAWYER DISCIPLINARY ENFORCEMENT R. 11(G) (2002); AM. BAR ASS'N, LAWYER REGULATION FOR A NEW CENTURY: REPORT OF THE COMMISSION ON EVALUATION OF DISCIPLINARY ENFORCEMENT 21-22, 49-52 (1992) [hereinafter MCKAY REPORT] (recommending the establishment of legal practice assistance committees to aid lawyers with practice problems, including those involved in lower-level misconduct). It has also been endorsed by the Conference of Chief Justices. See WORKING GRP. ON LAWYER CONDUCT \& Professionalism, A National action Plan on LaWyer Conduct and Professionalism 21 (1999) [hereinafter NATIONAL ACTION PLAN] (adopted by the Conference of Chief Justices on January 21, 1999); Levin, supra note 14, at 4 (noting in this 2007 article that twenty jurisdictions had adopted such diversion programs for minor misconduct at the time). 
To the extent the present contraction of the legal market has forced more new lawyers to enter solo practice without expertise or mentors, the need for remedial training will only grow.

\section{B. An Additional Paradigm for Identifying Lawyer Misconduct}

In this Article, I advocate adopting systems for the automatic reporting of certain lawyer conduct to disciplinary authorities in order to increase the information flow to regulators. I am not advocating that traditional reporting duties placed on individual lawyers and judges be eliminated, but only that an automatic reporting system should be adopted to complement those duties.

I have written elsewhere about how we can improve the reporting system for individual lawyers and judges. ${ }^{19}$ Reporting duties play a significant role not only in policing the profession, but also as a source of self-reflection as one decides whether or not particular behavior should be reported. ${ }^{20}$ These duties should be retained, but are not themselves sufficient. Increasing the information flow through automatic reporting will improve the lawyer disciplinary system. The information reported will, at times, involve conduct warranting discipline in its own right that would not otherwise come to the attention of disciplinary authorities. More minor misconduct would also be reported, which might warrant discipline in the aggregate or uncover lawyers in need of remedial assistance in practice.

This Article examines four automatic notification requirements that together would supplement the current reporting duties and provide more comprehensive data to disciplinary authorities.

The first two requirements involve reporting by entities outside the legal profession that interact with lawyers in significant ways. ${ }^{21}$ In many states, banks

For a contemporary discussion of two states' diversion programs, see Diane M. Ellis, $A$ Decade of Diversion: Empirical Evidence that Alternative Discipline Is Working for Arizona Lawyers, 52 EMORY L.J. 1221, 1221-23, 1266-70 (2003) (reporting favorably on the Arizona program), and Practice Assistance \& Improvement Comm., La. State Bar Ass'n, Nine Years: Practice Assistance, 55 LA. B.J. 118, 118 (2007) (describing the Louisiana program as a "booming success story"). But cf. Levin, supra note 14, at 3-6 \& n.26 (noting that, because of a lack of available data, it is not known whether diversion programs really work, and pointing out "serious limitations" in the Arizona empirical study cited above).

${ }^{19}$ See, e.g., Greenbaum, Attorney's Duty to Report, supra note 4, at 282-333; Greenbaum, Judicial Reporting, supra note 4, at 563-68.

${ }^{20}$ See, e.g., Greenbaum, Attorney's Duty to Report, supra note 4, at 281; Greenbaum, Judicial Reporting, supra note 4, at 553-54.

${ }^{21}$ See infra Parts II-III. Such entities may be enlisted in other ways to aid in the disciplinary process. For example, in fourteen states, when an insurance company makes a payment to a lawyer in settlement of a client's claim, which is the common practice, the insurer must notify the client that the payment has been made. Standing Comm. on Client Prot., Jurisdictions with Payee (Insurance) Notification, A.B.A. (Mar. 11, 2011), http://www.abanet.org/cpr/clientpro/payee_chart.pdf. Providing this notice can help deter a range of lawyer misconduct that includes entering into unauthorized settlement, forgery of 
are required to report lawyer overdrafts of client trust accounts to disciplinary authorities. ${ }^{22}$ In one state, malpractice insurers are required to report certain information about claims made against lawyers to disciplinary authorities. ${ }^{23}$ This practice is required by law for medical malpractice insurers in the United States. ${ }^{24}$ I would require reporting in both situations.

The third requirement would involve the courts more directly in reporting certain kinds of conduct to disciplinary authorities. ${ }^{25}$ Findings of contempt, the imposition of significant sanctions, and other matters of note would be reported automatically to disciplinary authorities.

The fourth requirement involves lawyer self-reporting when certain events occur. ${ }^{26}$ For example, a lawyer might be required to report to disciplinary authorities if the lawyer were convicted of a crime in any court or had disciplinary penalties entered against him in another state.

It should be noted that none of these ideas are new. Each has been adopted in some states, although some not widely so. The only state to adopt all of these provisions is California, and the adoption there was the product of a major scandal concerning the bar and massive legislatively imposed oversight enacted in response. ${ }^{27}$

Nevertheless, the literature on these automatic reporting devices is scant. None of the articles or studies attempt to systematically address the costs and benefits of these devices. ${ }^{28}$ Attempting to tease those out is at the core of this project.

In evaluating each of the potential automatic reporting devices, several factors should be considered, including:

- usefulness of the information to disciplinary authorities;

- burden of compliance on the reporting entity and others; ${ }^{29}$

settlement documents or of the claimant's endorsement on the settlement draft itself, or misappropriation of the claimant's share of the proceeds. MODEL RULE FOR PAYEE NOTIFICATION preface (2007). Absent some notice that settlement has been reached and a payment made, the lawyer may conceal these misdeeds for years by lying to the client about the fact that the matter has been settled and paid. Id.

22 See infra Part II.

${ }^{23}$ See infra note 70.

24 See infra text accompanying notes 73-74.

${ }^{25}$ See infra Part IV.

26 See infra Part V.

${ }^{27}$ See Gallagher, supra note 16 , at 560 .

${ }^{28}$ See, e.g., RHODE \& HAZARD, supra note 11, at 266 (advocating, without extensive analysis, that disciplinary authorities should "initiate investigations based on malpractice filings, judicial sanctions, and random audits of trust funds").

${ }^{29}$ In this Article I highlight some of the costs imposed by each of the reporting regimes discussed, but I do not attempt to quantify them. That is beyond the scope of this Article.

For a jurisdiction considering adopting any of these proposals, the Paperwork Reduction Act and government documents implementing it provide some guidance on how to perform such an analysis. See generally 44 U.S.C. $\S 3501$ (2006). Three principal concerns need to be kept in mind. 
- potential compliance problems; and

- indirect consequences.

Finally, the Article addresses the potential systemic problems flowing from an automatic reporting regime. ${ }^{30}$ These include possible misuse of the information by disciplinary authorities, system overload problems from an increased amount of reporting, and resource concerns in processing the increase in information flow.

\section{REPORTING BY ENTITIES OUTSIDE THE LEGAL PROFESSION--TRUST ACCOUNT OVERDRAFT NOTIFICATION}

A quite common automatic reporting system involving lawyers concerns lawyer trust account overdraft notification. Long advocated by the American Bar Association (ABA), ${ }^{31}$ such a system is now in place in forty-two

First, it is necessary to capture all of the activity the reporting requirement will engender for the reporter, affected third parties, and disciplinary authorities. $C f$. id. $\S 3502(2)$ (defining the paperwork burden to be measured to include the "time, effort, or financial resources expended by persons to generate, maintain, or provide information ... including the resources expended for-(A) reviewing instructions; (B) acquiring, installing, and utilizing technology and systems; (C) adjusting the existing ways to comply with any previously applicable instructions and requirements; (D) searching data sources; (E) completing and reviewing the collection of information; and (F) transmitting, or otherwise disclosing the information"); Guidelines for Ensuring and Maximizing the Quality, Objectivity, Utility, and Integrity of Information Disseminated by Federal Agencies, 66 Fed. Reg. 49,718, 49,719 (Sept. 28, 2001) (providing that, in evaluating paperwork requests, "agencies should weigh the costs (for example, including costs attributable to agency processing effort, respondent burden, maintenance of needed privacy, and assurances of suitable confidentiality)").

Second, the time involved in each of these activities must be quantified. When federal agencies attempt to do so for reporting requirements they adopt, they rely on such things as staff familiarity with the reporter, public comments, estimates from agency personnel completion of the reports, pilot tests, estimates based on the number of questions asked, and historical knowledge. See Office of INFo. \& Regulatory AfFaIRS, OfFice of MgMT. \& BUDGET, INFORMATION COLLECTION BUDGET OF THE UNITED STATES GOVERNMENT: FISCAL YEAR 1999, at 32 (1999), available at http://clinton2.nara.gov/omb/inforeg/icb-fy99.pdf.

Third, the personnel costs associated with these activities must be measured. When federal agencies attempt to do so for reporting requirements they adopt, they sometimes estimate the wage rate by using "sector-specific or occupation-specific" wage rates reported by the Bureau of Labor Statistics or by asking respondents to report their respective wages. Id. at 35. These wage rates must also take into account "overhead and fringe benefit costs associated with the employee's time." Id.

${ }^{30}$ See infra Part VI.

31 The ABA adopted a Model Rule on overdraft notification in 1988. See generally MODEL RULES FOR TRUST ACCOUNT OVERDRAFT NOTIFICATION (1988). It called again for its adoption in the context of a major review of lawyer discipline a few years later. See MCKAY REPORT, supra note 18, at 78-79 (advocating adoption of overdraft notification). Overdraft notification remains a recommended disciplinary procedure. See MODEL RULES 
jurisdictions. ${ }^{32}$ Under this system, banks that house lawyer trust accounts are required to notify disciplinary authorities whenever overdrafts and presentments against insufficient funds occur, whether or not the bank chooses to honor the instrument. ${ }^{33}$ Being proactive when potential misappropriation may be occurring is particularly apt. Misappropriation of client funds is a fundamental breach of trust between lawyer and client, and tarnishes the reputation of the profession as a whole. ${ }^{34}$

\section{A. Usefulness of the Information to Disciplinary Authorities}

On first look, required reporting of trust account overdrafts may seem unwarranted. In the usual case, there is a simple explanation for the overdraft. ${ }^{35}$ These include mathematical errors, not allowing enough time for checks to clear, making deposits to the wrong account, poor recordkeeping, and financial institution errors. ${ }^{36}$

FOR LAWYER DISCIPLINARY ENFORCEMENT R. 29(B) (2002). It also has been endorsed by the Conference of Chief Justices. See NATIONAL ACTION PLAN, supra note 18, at 23.

${ }^{32}$ See Standing Comm. on Client Prot., Ctr. for Prof'l Responsibility, Jurisdictions with

Trust Account Overdraft Notification Rules, A.B.A. (July 5, 2011), http://www.abanet.org/cpr/clientpro/trust_chart.pdf.

${ }^{33}$ For a model set of rules that establish an overdraft reporting system, see MODEL RULES FOR LAWYER DISCIPLINARY ENFORCEMENT R. 29 (2002). See also MODEL RULES FOR TRUST ACCOUNT OVERDRAFT NOTIFICATION (1988). Under these provisions only banks that agree to provide overdraft notification to disciplinary authorities are allowed to host lawyer trust accounts. Lawyers, as a condition of practice, agree to the release of this information to the authorities. MODEL RULES FOR LAWYER DISCIPLINARY ENFORCEMENT R. 29(B), (E); MODEL RULES FOR TRUST ACCOUNT OVERDRAFT NOTIFICATION R. 1, 4.

${ }^{34}$ See, e.g., Grim v. State Bar, 805 P.2d 941, 943 (Cal. 1991) ("Misappropriation is more than a grievous breach of professional ethics. It violates basic notions of honesty and endangers public confidence in the legal profession."); In re Bult, 419 N.W.2d 245, 248 (Wis. 1988) ("Misappropriation or conversion of client funds held in trust is one of the most serious acts of lawyer misconduct. It violates the fundamental principle of the lawyer-client relationship - the trust the client places in the lawyer and upon which the lawyer depends to properly represent the client."); see also Stephen R. Cochell, NSF Check/Overdraft Notification: Implementation Guidelines for Attorneys, UTAH B.J., Dec. 1996, at 25, 25 ("Misappropriation or mishandling of client funds undermines, if not destroys, public confidence in the administration of justice and the legal profession as a whole....[M]isappropriation or theft of client funds draws public criticism of the profession and detracts from the integral role played by lawyers in business and the administration of justice.").

${ }^{35}$ For example, during the first two years of the New Jersey overdraft protection program, $96.1 \%$ of the cases were adequately explained without the necessity of an audit. James R. Zazzali, Disciplining Attorneys: The New Jersey Experience, 1 GEo. J. LEGAL ETHICS 659, 686 (1988).

${ }^{36}$ See, e.g., James E. Aiken, Trust Account Overdraft Notification Rule, MonT. LAW., Aug. 2007, at 8, 8-9; Phil Pattee, What to Put in a Trust Account, and What to Take Out, Nev. LAw., May 2006, at 42, 42; Lynda C. Shely, The ABA Model Rules for Trust Account Notification and Model Rule for Payee Notification: Client Protection for the Next 
If the overdraft is usually easily explained and not the result of intentional misappropriation, then one might ask: Is the process worth it? Why should bank officials, the lawyer trust account holder, and disciplinary officials spend time on an exercise that so seldom bears fruit? ${ }^{37}$ Several justifications exist. First, because the compliance costs are comparatively low, ${ }^{38}$ the benefits can be modest but still worth the cost. Second, lawyer-based errors create a teaching moment. Many lawyers simply do not know how to manage a trust account well, and this brush with disciplinary authorities gives the latter the opportunity to educate the lawyer on proper practices. ${ }^{39}$ Third, the practice does uncover some instances of actual lawyer misuse of client money, ${ }^{40}$ often catching the practice while the amounts misappropriated are relatively small. ${ }^{41}$ Overdrafts may also serve as an early warning system for other problems in a lawyer's

Millennium, Prof. LAW., Spring 2000, at 23, 23; Carol Wilson, Watch Your Trust Account: Useful Reminders for Dealing with Money, OR. ST. B. BuLL., Apr. 1996, at 35, 35-36.

${ }^{37}$ In Montana, for example, there were only seven cases of misappropriation discovered through overdraft notifications in the first ten years of the program and none in the following two. Aiken, supra note 36, at 9. In Minnesota, during the fifteen-year period between 1991 and 2006, 1924 overdraft reports were submitted, with 153 resulting in some form of discipline, whether for misappropriation or other violations. Betty M. Shaw, Overdraft Notification, BENCH \& B. MINN., Apr. 2006, at 18, 18-19. Of those, only fortynine were sufficiently serious to warrant suspension or disbarment. Id. In 2009, the number was three. Martin Cole, Time Is Money, BENCH \& B. MINN., July 2010, at 14, 14. In New Jersey, information uncovered by overdraft notification was the "sole reason for the discipline" of 131 lawyers over a twenty-four-year period, roughly five or six a year. OFFICE

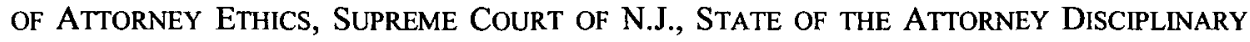
SYSTEM REPORT 24 (2009), available at http://www.judiciary.state.nj.us/oae/2009annual report.pdf.

${ }^{38}$ See infra Part II.B.

${ }^{39}$ See, e.g., Shely, supra note 36 , at 23 (noting that most overdrafts result from trust account management problems, which disciplinary counsel can help correct "by offering audits, record-keeping information, CLE and other law office management tools"); see also Shaw, supra note 37, at 19 (discussing the role of overdraft notification in providing an opportunity to educate reported lawyers about the proper handling of trust accounts). Although, if the lawyer's recordkeeping is particularly egregious, that may itself generate a disciplinary action. Glenn Grossman, Trust Account Recordkeeping, MD. B.J., Jan.-Feb. 2011 , at 54, 54; Wilson, supra note 36 , at 36 .

40 See supra note 37.

${ }^{41}$ MOdel RULES FOR TRUST ACCOUNT OVERDRAFT NOTIFICATION preface (1988) (describing overdraft notification as an "early warning" system, catching misappropriations "before major losses occur and [a] significant number of clients are harmed"). 
practice. ${ }^{42}$ Finally, lawyer knowledge that overdrafts will be reported and trigger an investigation has a deterrent effect on trust account misuse. ${ }^{43}$

\section{B. Burden of Compliance on Reporting Entity and Others}

The direct costs of adopting a trust account overdraft reporting system are comparatively low. First, the triggering act is clearly defined. Bank officials need not grapple with difficult questions about when their duty lies. ${ }^{44}$

Second, the cost imposed on the banking institutions is minimal. Banks already notify customers of overdrafts, ${ }^{45}$ and the same notice can be provided to disciplinary authorities, ${ }^{46}$ although some states do specify the contents of the required disciplinary notification. ${ }^{47}$ Some states have authorized electronic notification to further lower costs. ${ }^{48}$ The minimal costs that are incurred can be passed on to the account holder in overdraft fees. ${ }^{49}$

Even if the act of reporting is itself comparatively inexpensive, however, those costs may become significant if the number of reports required of a financial institution is high. Annual report data from the states give an indication of the number of reports being made in the aggregate, but not whether any particular financial institution is inordinately burdened. Nevertheless, the data provide a sense of the volume involved. The number of overdrafts likely to be reported in any particular state, in turn, will vary by the

42 Fellmeth, supra note 13 , at 60 (finding by the California State Bar Discipline Monitor that even where theft was not involved, overdrafts are "very predictive of inadequate office management skills[;] . . . are closely related to alcohol/drug abuse, mental breakdown, or organizational incompetence[;] . . . [and] also seem to correlate with attorneys who are the subject of subsequent complaints for refusing to answer calls, case abandonment, and legal malpractice").

${ }^{43}$ Several sources attribute the small number of misappropriations uncovered because of overdraft reporting as a reflection of the fact that the rule is in fact acting as a deterrent. Shely, supra note 36, at 23 (citing a comment to this effect from the Deputy Counsel of the North Carolina State Bar). This is particularly true where such instances have diminished over time as the rule has become more widely known. Aiken, supra note 36, at 9 (noting both the decrease over time in the number of overdraft notices and in the number of misappropriations uncovered by those notices).

${ }^{44}$ MODEL RULES FOR LAWYER DISCIPLINARY ENFORCEMENT R. $29 \mathrm{cmt}$. (2002).

$45 I d$.

${ }^{46}$ The proposition in the text is true to the extent there is an overdraft that the bank dishonors. To the extent instruments are presented against insufficient funds, but are nonetheless honored, the customer may not be notified. Here, the bank would be required to take additional steps. For a sample set of requirements, see $i d$. R. $29($ C)(2) (providing that "the report shall identify the financial institution, the lawyer or law firm, the account number, the date of presentation for payment, and the date paid, as well as the amount of overdraft created thereby").

${ }^{47}$ See, e.g., MiCH. R. OF Prof. CONDUCT 1.15A(d) (setting out the information that banks must provide in Michigan to disciplinary authorities in overdraft notification).

48 See, e.g., OHIO REV. CODE ANN. § 4705.10(A)(4) (West Supp. 2011).

${ }^{49}$ MODEL RULES FOR LAWYER DISCIPLINARY ENFORCEMENT R. 29(F). 
size of the state's bar, the diligence of the reporting entities, the economic health of the legal community, and the competence of the state's lawyers in trust account management. At one end of the spectrum, California has received between 1811 and 3031 overdraft notifications per year during the period from 2005 to $2009 . .^{50}$ The numbers in other states, however, are far more modest and would not seem to impose a significant burden. ${ }^{51}$

That said, there also are indirect costs that must be considered. The first is potential liability from participation in an overdraft notification program. One concern is possible liability to lawyer account holders for the disclosure of their private information to disciplinary authorities. This concern is usually met by conditioning the law license on agreeing to this release of information. ${ }^{52}$ Even if the bank's report turns out to be erroneous, liability to the lawyer is unlikely to arise. ${ }^{53}$

${ }^{50}$ STATE BAR OF CAL., 2009 REPORT ON THE STATE BAR OF CALIFORNIA Discipline SYSTEM 6 (2010) [hereinafter 2009 CALIFORNIA DISCIPLINE SYSTEM REPORT], available at http://www.calbar.ca.gov/LinkClick.aspx?fileticket=JL320GTHvEo\%3D\&tabid=1251. In 2010, there were 2929 such reports. STATE BAR OF. CAL., ATTORNEY DISCIPLINE REPORT FOR YEAR ENDING DECEMBER 31, 2010, at 44 (2011) [hereinafter 2010 CALIFORNIA ATTORNEY DISCIPLINE REPORT], available at http://www.calbar.ca.gov/LinkClick.aspx?fileticket=CXf BIG0tHQ4\%3D\&tabid=224\&mid=1534.

${ }^{51}$ For example, Arkansas received fifty overdraft reports in 2009 and forty-seven in 2010. Comm. on Prof'l Conduct \& OfFice of Prof'l Conduct, ARK. SuPreme CourT, 2010 ANNUAL REPORT 8 (2010), available at https://courts.arkansas.gov/opc/annual_report/ 2010_Report.pdf. Minnesota received seventy-eight overdraft notifications in 2008 and eighty-one in 2009. JUDITH M. RUSH \& MARTIN A. COLE, ANNUAL REPORT OF THE LAWYERS PROFESSIONAL RESPONSIBILITY BOARD \& ANNUAL REPORT OF THE OFFICE OF LAWYERS PROFESSIONAL RESPONSIBILITY 20 (2010), available at http://prb.mncourts.gov/AboutUs/ Documents $/ 2010 \% 20$ Annual\%20Report.pdf. Washington had 152 reports in 2010. WASH. STATE BAR ASS'N, 2010 LAWYER DISCIPLINE SYSTEM ANNUAL REPORT 11 (2010), available at http://www.wsba.org/ /media/Files/Licensing_Lawyer\%20Conduct/Discipline $/ 2010 \%$ 20Lawyer\%20Discipline\%20System\%20Annual\%20Report.ashx. Wisconsin had 104 overdraft reports in fiscal year 2009, 69 in 2008, and 96 in 2007. WIS. OFFICE OF LAWYER REGULATION \& BD. OF ADMIN. OVERSIGHT, ANNUAL REPORT FISCAL YEAR 2008-2009, at 7 (2009), available at http://www.wicourts.gov/courts/offices/docs/olr0809fiscal.pdf. Tennessee received eighty during the period between July 1, 2005, and June 30, 2006, and sixty-one the year before. BD. OF PROF'L RESPONSIBILITY, SUPREME COURT OF TENN., THIRTIETH ANNUAL REPORT: JULY 1, 2005 THROUGH JUNE 30, 2006, at 1 (2006), available at http://www.tbpr.org/NewsAndPublications/AnnualReports/Pdfs/annualreport30th.pdf; BD. OF PROF'L RESPONSIBILITY, SUPREME COURT OF TENN., TWENTY-NINTH ANNUAL REPORT: JULY 1, 2004 THROUGH JUNE 30, 2005, at 1 (2005), available at http://www.tbpr.org/News AndPublications/AnnualReports/Pdfs/annualreport29th.pdf. In subsequent years that number has risen, peaking at 146 in the last fiscal year. E-mail from Daphna Burney, Tenn. Bd. of Prof'l Responsibility, to Timothy Bower (July 19, 201 1, 12:46 PM EST) (on file with author):

52 MODEL RULES FOR LAWYER DISCIPLINARY ENFORCEMENT R. 29(E) \& cmt. (conditioning attorney licensure on consent to such reporting). There may also be a clause in the contract between the bank and the lawyer account holder limiting liability. Cochell, supra note 34, at 25.

${ }^{53}$ This later protection is sometimes expressly addressed in the documents creating the overdraft notification process. See, e.g., DEL. R. PROF. CONDUCT 1.15A(f). That said, the 
Failing to report potentially poses a more difficult problem. If client funds are misappropriated after a bank fails to provide a required overdraft report, the bank may be liable to the lawyer's clients, whose funds are misappropriated, and to the state's client protection fund, if it compensates the clients for their losses. ${ }^{54}$ If desired, however, this threat can be limited. Some states appear to provide financial institutions absolute immunity for liability in these circumstances. ${ }^{55}$ Others provide more limited immunity. ${ }^{56}$ Even if no immunity provision is present, some courts have found that liability does not flow simply from failing to follow the reporting requirement. ${ }^{57}$

A second indirect cost flows from the actions necessary in the aftermath of reporting. The overdraft notification is likely to lead to further investigation by disciplinary authorities. Responding to those inquiries by either the bank or the lawyer involved will impose additional burdens. ${ }^{58}$

immunity may not lie if the bank acts in bad faith in making the report. See, e.g., IND. ADMISSION \& DISCIPLINE R. 25(8)(c) (immunity extends to required reports and those "believed to be in good faith to be required").

${ }^{54}$ Model RUles for Trust ACCOUNT OVERDRAFt NOTIFICATION R. 2 cmt. 4 (1988) (recognizing both these concerns).

55 See, e.g., COLO. R. PROF. CONDUCT 1.15(e)(3) ("A financial institution shall be immune from suit arising out of its actions or omissions in reporting overdrafts or insufficient funds or producing documents under this Rule. The agreement entered into by a financial institution with the Regulation Counsel shall not be deemed to create a duty to exercise a standard of care and shall not constitute a contract for the benefit of any third parties that may sustain a loss as a result of lawyers overdrawing lawyer trust accounts."); TENN. SUP. CT. R. $9 \S 29.1$ (F) ("Nothing herein shall create or operate as a liability of any kind or nature against any financial institution for any of its actions or omissions in reporting overdrafts or insufficient funds to the Board.").

${ }^{56}$ See, e.g., 204 PA. CODE $\$ 91.173$ (b) (2009) ("Enforcement Rule 221(k) provides that a failure on the part of an Eligible Institution to make a report called for by this subchapter may be cause for termination of its approval by the Supreme Court, but such failure shall not, absent gross negligence, give rise to a cause of action by any person who is proximately caused harm thereby." (emphasis added)).

57 See, e.g., McCartney v. Richfield Bank \& Trust Co., Nos. CX-00-1466, C1-00-1467, 2001 WL 436154, at *3-5 (Minn. Ct. App. May 1, 2001); Home Sav. of Am., FSB v. Amoros, 661 N.Y.S.2d 635, 639 (App. Div. 1997) (noting that "we are not of the view that the bank's evident default in the performance of its regulatory obligation to make a report of check dishonor suffices to establish its liability for the loss occasioned by Amoros' misappropriation," but only that "such default may be adduced as some evidence of the bank's negligence").

58 Timothy P. McMahon, Rule 1.15(e) of the Rules of Professional Conduct: A Banker's Perspective on Section (e) Compliance, 69 ALA. LAW. 103, 104 (2008) (noting complaints of three lawyers who had overdrafts reported, in their opinion in error, about "the time-consuming nature of the inquiry for both [disciplinary authorities] and the lawyer[s]"). This process, as it applies in Utah, was explained in the following terms:

Upon receipt of an NSF check/overdraft notice, the OAD will usually contact the attorney or law firm requesting an explanation. In most cases, the initial OAD contact will immediately be followed by a letter formally requesting a documented explanation within ten (10) business days from the date of the formal request. 
Overdraft notification could also have an impact on a state's client security fund if those notices uncover lawyer thefts that might otherwise go undetected. The chance of a significant impact appears small as it will likely be offset by the misappropriations caught early on or deterred entirely by the program. ${ }^{59}$

\section{Potential Compliance Problems}

Given the widespread use of the device and the experience of banks giving notice when an overdraft occurs, it is likely that there is substantial compliance with such requirements. Nevertheless, at least one author reports that noncompliance in his state, Alabama, is common, attributable in large measure to the bank personnel's ignorance of the requirement. ${ }^{60}$ Whether this is due to vagaries of the Alabama system or symptomatic of a more widespread problem is unclear. Certainly if banks want to retain the right to hold lawyer trust accounts, a right that could be revoked for noncompliance with the notification requirements, ${ }^{61}$ it is likely that the problem is not severe nationwide.

\section{Indirect Consequences}

Theoretically, if bank officials are required to report overdrafts of lawyer trust accounts to disciplinary authorities, lawyers might simply not create such accounts and stash client funds elsewhere. That is such a fundamental breach of the lawyer's ethical duties in handling client funds, ${ }^{62}$ however, that it is hard to

If bank error is claimed, an affidavit from a bank officer should be submitted. If attorney error is claimed, for example, a claim that a check was incorrectly deposited to another account by office personnel, an affidavit from the appropriate office personnel together with a copy of the dated slip showing deposit to the incorrect account will be required. Most inquiries will be concluded in this manner.

Cochell, supra note 34, at 25; see also Rhonda Spencer Pozehl, TAON-An Oversight Enhancement, MICH. B.J., Aug. 2010, at 22, 23 (describing the postnotification responsibilities of lawyers).

${ }^{59}$ See Pozehl, supra note 58, at 22 (noting that the newly adopted overdraft notification program is expected to "conserve substantial resources" for the state's client protection fund); $c f$. William J. Wernz, Overdraft Notice Rule, BENCH \& B. MINN., Nov. 1988, at 14, 14 (raising these issues and noting that even if more successful claims were made, it would mean only that more harmed clients would receive some compensation, which is the goal of client security funds).

${ }^{60}$ McMahon, supra note 58, at 104.

61 See Model Rules for Trust ACCOUNT Overdraft Notification R. 2 cmt. 5 (1988) (discussing revocation option); Shaw, supra note 37, at 18 (noting that in Minnesota, when banks were not fully complying with the overdraft notification requirement, the Office of Lawyers Professional Responsibility worked with those banks to establish procedures to assure compliance "so that the banks did not have to be decertified").

62 The requirement to keep client funds in an account separate from the lawyer's own property is well-established. See generally MODEL RULES OF PROF'L CONDUCT R. 1.15(a) (2009). It is part of the duty to safeguard client property, which is a "fundamental, fiduciary 
believe the presence or absence of an overdraft reporting requirement would affect lawyer behavior in that way. Certainly nothing in the literature suggests this has occurred.

It is also possible that some banks will decide not to offer trust account services to lawyers as a way to avoid the reporting duty. While some banks have resisted the adoption of such a rule, ${ }^{63}$ the literature does not suggest that states that have adopted such a rule have encountered a problem in finding willing financial institutions to participate in the program. ${ }^{64}$

Some have argued that imposing an overdraft reporting duty stigmatizes lawyers as untrustworthy and thus undercuts the lawyer-client relationship. ${ }^{65}$ Given that most of the conduct uncovered by overdraft notification does not involve dishonesty, the stigmatization argument seems overblown. As to the lawyer-client relationship, one suspects that most clients do not even know that such a program exists, and to the extent they do, are pleased that this safeguard is in place.

The presence of such a system also might create a greater sense of security in the safety of client funds than is warranted. All this system does is alert disciplinary authorities when a client trust account has insufficient funds to pay a demand upon it. Yet, misappropriation often takes place without ever triggering the reporting requirement. As long as the flow of cash in the account is sufficient, an unscrupulous lawyer could siphon some client money out of the account for his own purposes and cover up that fact for an extended period of time. For example, if Lawyer $A$ has cash flow problems in his business, he might misappropriate client funds and then later replace them. As long as there were always sufficient funds whenever a payment from the trust account was required, notification would never be triggered. ${ }^{66}$

This latter concern, however, simply reflects that overdraft notification is not, in and of itself, a solution to lawyer misappropriation. It is but one tool,

obligation of lawyers." Melissa DeLacerda, Should Oklahoma Adopt Trust Account Overdraft Notification?, 76 OKLA. B.J. 2831, 2831 (2005).

${ }^{63}$ See, e.g., Marilyn Lindgren Cohen, Coming Soon to a Bank Near You: Trust Account Overdraft Notification, OR. ST. B. BULL., Aug.-Sept. 1993, at 49, 49 (noting opposition by the Oregon Bankers Association in the early 1990s to original notification proposal).

${ }^{64}$ See, e.g., Stan Hazlett, The Changing Disciplinary Process, J. KAN. B. ASS'N, Jan. 2002 , at 14,14 (noting that 330 of approximately 360 financial institutions offering checking accounts agreed to participate in the Kansas overdraft notification program).

${ }^{65}$ Cf. John P. Sahl, The Public Hazard of Lawyer Self-Regulation: Learning from Ohio's Struggle to Reform Its Disciplinary System, 68 U. CIN. L. REV. 65, 81 n.60 (1999) (citing this as a reason for Ohio's one-time rejection of overdraft notification).

${ }^{66}$ See, e.g., Wernz, supra note 59 , at 14 (discussing this point and also that misappropriation often occurs by diverting money before it is deposited in the trust account or by lawyers who manage financial affairs of their clients and steal directly from their clients' personal accounts). 
along with random audits, ${ }^{67}$ payee notification, ${ }^{68}$ and client complaints, that helps police the area.

\section{E. Recommendation}

On balance it seems that overdraft reporting has been a success. It has been adopted in forty-two jurisdictions with few complaints about its operation. ${ }^{69}$ The costs it imposes are relatively small, and the indirect consequences are more theoretical than real. In contrast, the benefits of discouraging misappropriations, catching misappropriations that do occur (often at an early stage), and providing an avenue for remediation for those who cannot properly administer a trust account seem well worth the costs.

\section{REPORTING BY ENTITIES OUTSIDE THE LEGAL PROFESSION- MALPRACTICE NOTIFICATION}

A less common form of automatic reporting relates to professional liability claims made against lawyers. Both California and Florida have systems in place that require malpractice insurers to report certain actions against lawyers to state officials. $^{70}$ In California, those who are self-insured have similar duties. ${ }^{71}$

${ }^{67}$ Twelve states have adopted random audit requirements for lawyer IOLTA accounts. See Standing Comm. on Client Prot., State by State Adoption of ABA Client Protection Programs, A.B.A. (July 5, 2011) http://www.americanbar.org/content/dam/aba/migrated/cpr/ clientpro/statebystate_cp_programs.authcheckdam.pdf.

${ }^{68}$ See supra note 21 .

${ }^{69}$ See supra note 32.

${ }^{70}$ See CAL. BUS. \& PROF. CODE $\S 6086.8$ (b) (West 2003) (requiring insurers to report to the State Bar of California any claims or actions for damages against a member of the State Bar of Califomia they cover for fraud, misrepresentation, breach of fiduciary duty, or negligence committed in a professional capacity); FLA. STAT. ANN. § 627.912(1)(a), (c)(4) (West 2011) (requiring those who insure members of the Florida Bar to report to the Florida Department of Insurance "any written claim or action for damages for personal injuries claimed to have been caused by error, omission, or negligence in the performance of such insured's professional services," if the claim resulted in a final judgment against the provider and the appeal has expired, settlement in any amount, an indemnity payment to a provider, or loss adjustment expenses in excess of $\$ 5000$ ).

71 The California code imposes a number of analogous duties on lawyers. To the extent a lawyer is self-insured, the lawyer must report "any settlement, judgment, or arbitration award" involving a claim or action for damages for fraud, misrepresentation, breach of fiduciary duty, or negligence committed in a professional capacity. CAL. BUS. \& PROF. CODE $\S 6086.8(\mathrm{c})$. Whether or not insured, every lawyer must report " $[t]$ he filing of three or more lawsuits in a 12-month period against the attorney for malpractice or other wrongful conduct committed in a professional capacity." Id. $\S 6068(0)(1)$ (West 2003 \& Supp. 2012). Similarly, every lawyer must report " $[\mathrm{t}]$ he entry of judgment against the attorney in any civil action for fraud, misrepresentation, breach of fiduciary duty, or gross negligence committed in a professional capacity." $I d . \S 6068(0)(2)$. For a discussion of lawyer self-reporting duties, see infra Part V. 
Perhaps because of the limited adoption of this type of reporting requirement, there is scant literature about it. ${ }^{72}$

In contrast to lawyer regulation, in which such reporting is rarely required, it is common in the medical area where reporting is required on both the national ${ }^{73}$ and state levels. ${ }^{74}$ Exploring the medical community's experiences with such systems may provide insights into the drafting of such systems for lawyers.

\section{A. Usefulness of the Information to Disciplinary Authorities}

The first issue to address is the relevance of malpractice data to the disciplinary process. The civil liability system and the disciplinary system are

72 While these provisions are occasionally noted in the literature, I have found no comprehensive assessment of them. Perhaps the most extensive comments are found in the work of Manuel Ramos. See, e.g., Manuel R. Ramos, Legal Malpractice: The Profession's Dirty Little Secret, 47 VAND. L. REV. 1657, 1666-67, 1726 (1994) [hereinafter Ramos, Dirty Little Secret] (noting the existence of the mandatory reporting statutes in California and Florida, highlighting the compliance problems each encounters, and endorsing mandatory reporting of closed legal malpractice claims); see also Manuel R. Ramos, Legal Malpractice: No Lawyer or Client Is Safe, 47 FLA. L. REv. 1, 22-58 (1995) [hereinafter Ramos, No Lawyer or Client Is Safe] (relying on data reported under the Florida statute to assess the determinants of which lawyers are likely to face malpractice claims).

Similarly, there are no comprehensive data on the number of malpractice claims made against lawyers in the United States or an analysis of those claims. See 1 RoNALD E. MALlEN \& JefFrey M. SMITH, Legal MalPractice $\S 1: 6$, at 24 (2011 ed.) ("The availability of statistics on current claims frequency and severity is scarce."); Maute, supra note 3, at 67 ("Reliable statistical data is scarce and its use 'fraught with peril."). Perhaps the most cited are the reports by the ABA's Standing Committee on Lawyers' Professional Liability. For their most recent report, see STANDING COMM. ON LAWYERS' PROF'L LIAB., AM. Bar Ass'N, Profile of Legal MalPractice Claims: 2004-2007 (2008) [hereinafter PRofile of LEGAl MALPRACTICE Claims]. While useful, the study has its limitations, as its authors acknowledge. Id. at 3, 17 (noting, among other things, that the study is based on selfreporting by a subset of insurers, does not include unreported claims or claims against uninsured lawyers, and underrepresents the experiences at middle-sized and large firms).

${ }^{73}$ See 45 C.F.R. $\$ 60.1$ (2010) ("The Health Care Quality Improvement Act of 1986 ... authorizes the Secretary to establish ... a National Practitioner Data Bank . ..."); see also Health Care Quality Improvement Act of 1986, 42 U.S.C. $\$ \$ 11101-11152$ (2006) (establishing the National Practitioner Data Bank to serve as a national repository of information about physicians and other medical personnel, including information about adverse malpractice settlements and judgments); id. $\S 11131$ (malpractice reporting section of the Act).

${ }^{74}$ Reports to the National Practitioner Data Bank must also be made to state licensing boards. 42 U.S.C. $\S 11134(\mathrm{c})$. States also impose additional malpractice reporting requirements. See, e.g., Colo. Rev. STAT. §10-1-120 (2011); OHIO REv. CODE ANN. $\S 4731.224(D)$ (West Supp. 2011); see also Blanca Fromm, Note, Bringing Settlement Out of the Shadow: Information About Settlement in an Age of Confidentiality, 48 UCLA L. REV. 663, 678 (2001) ("Many state statutes similarly require health care professionals or their insurers to report settlements in professional malpractice cases to the state medical board or the state department of insurance."). 
different in function and focus. The former exists to compensate those injured by lawyer malfeasance, whereas the latter exists to protect the public from future harm, as well as to promote confidence in the judicial system and in the legal profession..$^{75}$ Nevertheless, they clearly overlap. Questions of competence, breach of fiduciary duty, and the like are treated in both systems. ${ }^{76}$ Data from civil claims can be informative, even if not dispositive, in disciplinary actions. ${ }^{77}$ Take, for example, the basic duties of competence and diligence and their interrelationship with malpractice. A single act of incompetence or neglect usually is not enough, standing alone, to warrant discipline, but a pattern of such conduct is. ${ }^{78}$ Maintaining a central repository of such information will help to show such patterns. ${ }^{79}$

75 See, e.g., RESTATEMENT (THIRD) OF THE LAW GOVERNING LAWYERS $\S 94(2) \mathrm{cmt}$. c (2000); see also Daniel L. Draisen, The Model Rules of Professional Conduct and Their Relationship to Legal Malpractice Actions: A Practical Approach to the Use of the Rules, 21 J. Legal Prof. 67, 75, 86-87 (1997); Douglas R. Richmond, Why Legal Ethics Rules Are Relevant to Lawyer Liability, 38 ST. MARY's L.J. 929, 948-51, 960-61 (2007). That said, the disciplinary system does provide some compensation through client security funds in instances in which a lawyer misappropriates client funds and those funds cannot be recouped through the civil liability system. See generally MODEL RULES FOR LAWYERS' FUNDS FOR CLIENT PRoteCtion (1989).

${ }^{76} \mathrm{Cf}$. MALLEN \& SMITH, supra note $72, \S 1: 8$.

${ }^{77}$ See, e.g., Martin A. Cole, When Malpractice Is an Ethics Issue, BENCH \& B. MINN., Dec. 2002, at 10, 10-11 ("A malpractice verdict or judgment is not per se proof of a disciplinary violation. Nevertheless, the Director's Office certainly can and does make use of findings from related civil proceedings. For example, sanctions imposed on attorneys may be reported to the director by a court for disciplinary investigation. Due to the likely differences in burdens of persuasion, the findings will not be conclusive. In some instances, such as where a complete contested trial record is available, particularly in cases of fraud or breach of fiduciary duty, the director may offer substantial portions of the record and argue that this same evidence also meets the higher clear and convincing evidence standard that applies in lawyer discipline cases.").

${ }^{78}$ See, e.g., MALLEN \& SMITH, supra note $72, \S 1: 9$, at 51 ("Ordinary negligence should not warrant discipline."); Cole, supra note 77 , at 10 ("[A] single mistake by an attorney, even if actionable as malpractice, is highly unlikely to result in professional discipline of the attorney... [but] neglecting a matter for several years such that the applicable statute of limitations expires certainly may constitute malpractice. It can and will just as certainly be considered a disciplinary matter involving neglect."); Stephen E. Schemenauer, What We've Got Here... Is a Failure ... to Communicate: A Statistical Analysis of the Nation's Most Common Ethical Complaint, 30 HamLINE L. REV. 629, 675 (2007) (explaining that "[w]hile New Jersey does not discipline single instances of simple neglect, multiple instances of simple neglect may form a pattern that will constitute unethical conduct"). My experience on a local grievance committee in Ohio is that when a case comes up that has malpractice implications and the threat of harm to others is not evident, the committee often defers to the civil liability system to resolve the wrong.

${ }^{79}$ There are no good data on the extent to which individual lawyers engage in multiple acts of neglect or otherwise breach their duties. It has been estimated that many individual lawyers will have multiple malpractice claims made against them over their careers. See, e.g., James M. Fischer, External Control over the American Bar, 19 GeO. J. LEGAL ETHICS 59,63 (2006) (reporting the "often cited figure that the average lawyer will be sued for 
Further, in a preventive or rehabilitative disciplinary model-which envisions catching incompetent acts early, assessing whether the lawyer is likely to encounter further problems, and providing assistance where she isknowing about even the first instance of potential incompetence or neglect is important.

While the issues posed by. civil claims against lawyers for actions taken in their professional capacity often touch on issues that are regulated by the disciplinary system as well, the real question is whether claims-related information is sufficiently reliable to justify its reporting. In the medical area, the medical profession has long asserted that malpractice data as to claims made or their resolution are in fact often unreliable. ${ }^{80}$

malpractice three times over his career"); Ramos, Dirty Little Secret, supra note 72, at 1665 n.49 (noting the often cited figure, but concluding the average lawyer is more likely to face six legal malpractice claims). In a study of malpractice claims reported under Florida's mandatory reporting scheme, 232 lawyers had two or more reported claims between November 1988 and January 1994. Ramos, No Lawyer or Client Is Safe, supra note 72, at 53.

In the medical field, $33 \%$ of the physicians that had malpractice payment reports in the National Practitioner Data Bank had two or more such reports. DIV. OF PRACTITIONER DATA Banks, U.S. Dep'T OF Health \& Human Servs., National Practitioner Data Bank: 2006 ANNUAL REPORT 42 (2006), available at http://www.npdb-hipdb.hrsa.gov/resources/ reports/2006NPDBAnnualReport.pdf.

In Ohio, malpractice insurers are required to report to the state medical board any final disposition of any written claim for damages in excess of $\$ 25,000$ against a doctor. OHIO REV. CODE ANN. $\S 4731.224$ (D) (West Supp. 2011). Because that information is in the medical board's file for each doctor, it is available to help show a pattern of misconduct whenever a complaint against that doctor is made. The state medical board is also required to investigate whenever a doctor has three such reports in a five-year period involving negligent conduct. Id. $\S 4731.224(\mathrm{E})$. In 2007, investigations of twenty-five doctors were triggered by this process. Telephone Interview with Diann Thompson, Assistant Exec. Dir. for Pub. Servs., Licensure \& Renewal, State Med. Bd. of Ohio (May 2009) (notes on file with author).

${ }^{80}$ Another concern about malpractice reporting in the medical field is that the data do not reflect the difference in risk in certain kinds of medicine, making the number of reported claims against a particular doctor, standing alone, an inaccurate point of comparison between doctors in different fields. See Letter from Michael D. Maves, M.D., M.B.A., Exec. Vice President \& Chief Exec. Officer, Am. Med. Ass'n, to Betsy Ranslow, Assoc. Adm'r, Bureau of Health Professions, Health Res. \& Servs. Admin. 2 (May 22, 2006) [hereinafter Maves], available at http://www.ama-assn.org/ama1/pub/upload/mm/395/ama_comments_npdb.pdf. Underreporting problems also make such comparisons somewhat unreliable since the data set is incomplete. See Public Access to the National Practitioner Data Bank: Hearing on Assessing the Operation of the National Practitioner Data Bank Before the H. Subcomm. on Oversight \& Investigations of the Comm., on Commerce, 106th Cong. 126 (2000) [hereinafter Public Access to the NPDB: Hearing on Assessing Operation]; Public Access to the National Practitioner Data Bank: Hearing on What Consumers Should Know About Their Doctors Before the H. Subcomm. on Oversight \& Investigations of the Comm. on Commerce, 106th Cong. 9 (2000) [hereinafter Public Access to the NPDB: Hearing on What Consumers Should Know]. In the system I propose, where the information is only used to build a file for each lawyer to be used only by disciplinary authorities, these problems would 
One constant critique of the reporting of medical malpractice claims is that the predictive nature of the reported data is low. Looking at all filed claims, many turn out to be without merit. ${ }^{81}$ Even for claims that settle, the settlement often reflects an economic decision about the costs of defense, rather than the presence of true misconduct. ${ }^{82}$ And for those cases that go to trial and result in a plaintiff's verdict, studies show that in many instances experts would have assessed those cases differently. ${ }^{83}$

That critique, however, may be overstated. Others report that filed claims often reflect doctor error, ${ }^{84}$ even if they result in no settlement or award ${ }^{85}$ Further, claim determinations are strongly correlated with the merits of the underlying claims. ${ }^{86}$

not arise. That said, there may well be pressure for making such information public. See Steven K. Berenson, Is It Time for Lawyer Profiles?, 70 FORDHAM L. REV. 645, 684 (2001) (arguing for publicly available lawyer profiles that would include information about lawyer malpractice payments above \$5000); Benjamin P. Cooper, Attorney Self-Disclosure, 79 U. CIN. L. REV. 697, 711-12, 743 (2010) (arguing that information about lawyer malpractice payments above $\$ 5000$ should be given to prospective clients by the lawyer consulted). In fact, the lawyer malpractice information reported in Florida is publicly available at Professional Liability Claims Reporting, FLA. OFF. OF INS. REG., https://apps.fldfs.com/ PLCR/Search/LPLClaim.aspx (last visited Mar. 9, 2012).

81 See Carole Roan Gresenz et al., A Flood of Litigation? Predicting the Consequences of Changing Legal Remedies Available to ERISA Beneficiaries, RAND HEALTH L., 1, 5 (1999), http://www.rand.org/content/dam/rand/pubs/issue_papers/2006/IP184.pdf (concluding, from a review of four studies done in the late $1980 \mathrm{~s}$ and early 1990s, that between one-half to two-thirds of all medical malpractice claims have no apparent indication of negligence); see also OfFICE OF INSPECTOR GEN., DEP'T OF HEALTH \& HuMAN SERvs., OEI-01-09-00521, National Practitioner Data Bank: Malpractice REPORTING REQUIREMENTS 3 (1992) [hereinafter NPDB, MALPRACTICE REPORTING REQUIREMENTS], available at http://oig.hhs.gov/oei/reports/oei-01-90-00521.pdf.

82 See Public Access to the NPDB: Hearing on What Consumers Should Know, supra note 80, at 60,63 (testimony of American Medical Association president stating that only between $20 \%$ and $30 \%$ of malpractice settlements result from negligent medical care); Maves, supra note 80 , at 2.

${ }^{83}$ Maves, supra note 80 , at 2.

${ }^{84}$ David M. Studdert et al., Claims, Errors, and Compensation Payments in Medical Malpractice Litigation, 354 NEW ENG. J. MED. 2024, 2028 fig.1 (2006) (finding that in 97\% of the filed claims studied the patient had been injured, and that $63 \%$ of those involved medical error).

${ }^{85} \mathrm{Id}$. at 2028 (noting that in $16 \%$ of the studied cases, no payments were made even with the presence of medical error).

${ }^{86}$ Id. (finding that in $73 \%$ of the claims studied, the outcomes were concordant with the merits and that in only $10 \%$ were there payments made in the absence of medical error). After an extensive review and critique of the major studies on the accuracy of outcomes in medical malpractice claims, Professor Philip Peters concluded:

[M]edical malpractice settlements are neither random nor irrational. Both the likelihood of a settlement payment and the amount paid in settlement are closely related to the merit of the underlying claim of medical negligence. Both are the products of an insurance-claims process that acts much like peer review. Payment is most likely when 
To conclude that the reporting of malpractice information is potentially helpful in the disciplinary process still begs the question of what should be reported. One option is to report every claim made for malpractice against an attorney. Alternatively, the focus might be on resolved cases in which some relief is afforded, whether by settlement or judgment. Most restrictive would be a reporting scheme limited to instances where a lawyer was adjudicated as at fault in a malpractice action.

The last standard, while providing a comparatively high quality of information, ${ }^{87}$ would be too restrictive. In one national study, less than $1 \%$ of the lawyer malpractice claims went to trial and resulted in a judgment for the plaintiff. ${ }^{88}$ The instances of negligence or other breaches of duty clearly are much higher.

Applying a claims-paid standard would enlarge the pool of reported information. In the legal field, it has been estimated that payments on malpractice claims, whether by settlement or trial, occur in almost $30 \%$ of the claims. ${ }^{89}$ While many of the settlements may be mere business judgments about the relative economic merits of settling or proceeding to trial, those judgments are informed by the likelihood that lawyer malfeasance could be proven. ${ }^{90}$ If

the quality of care was poor, less likely when it was uncertain, and least likely when it was good. Settlement amounts are likely to be lowest when the quality of care was good, higher when care quality was too close to call, and highest when care quality was poor.

Philip G. Peters, Jr., What We Know About Malpractice Settlements, 92 Iowa L. REV. 1783, 1831-32 (2007).

${ }^{87}$ Given that disciplinary actions are governed by a clear and convincing evidence standard, whereas civil proceedings are governed by the preponderance of the evidence standard, a finding of lawyer misconduct in the latter is not conclusive in the former. See supra note 77.

88 Profile of Legal MalPractice Claims, supra note 72, at 9 tbl.4; see also Or. State Bar Prof'l Liab. Fund, 2010 ANNUAL RePORT 4 (2010) [hereinafter 2010 OREGON REPORT]; OR. STATE BAR PROF'L LIAB. Fund, 2009 ANNUAL REPORT 4 (2009) [hereinafter 2009 Oregon Report]; Or. State Bar Prof'l Liab. Fund, 2008 AnNual Report 4 (2008) [hereinafter 2008 Oregon RePORT]; Or. STATE Bar Prof'L Liab. Fund, 2007 ANNUAL REPORT 4 (2007) [hereinafter 2007 OREGON REPORT]. Each report indicates that for the given year only $1 \%$ of the malpractice cases resolved against Oregon lawyers terminated in judgment for a plaintiff.

89 Profile of Legal Malpractice Claims, supra note 72, at 9 tbl.4. Statistics from Oregon show a slightly higher percentage of payouts-between $35 \%$ and $36 \% .2010$ OREGON REPORT, supra note 88, at 4; 2009 OREGON REPORT, supra note 88, at 4; 2008 OREGON REPORT, supra note 88, at 4; 2007 OREGON REPORT, supra note 88, at 4.

${ }^{90}$ This is indirectly supported by the fact that of all the claims made against lawyers, more than half typically are simply abandoned by claimants without receiving any compensation, in part because, on reflection, the merits of the claims seemed weak. PROFILE OF LEGAl MALPRACTICE ClaIMS, supra note 72, at 9 tbl.4. Statistics from Oregon show lower abandonment rates between $19 \%$ and $22 \% .2010$ OREGON REPORT, supra note 88 , at 4; 2009 OREGON REPORT, supra note 88, at 4; 2008 OREGON REPORT, supra note 88, at 4; 2007 OREGON REPORT, supra note 88 , at 4 . It is unclear if these reports employ different criteria in 
one is concerned that low settlements most often reflect settlement value, rather than possible lawyer malfeasance, the reporting requirement could be limited to resolutions over a certain dollar amount. ${ }^{91}$ Yet one should not be too quick to conclude that claims resulting in small settlements carry little useful information. One study in the medical field, which compared malpractice claims resolved for less than $\$ 30,000$ (a threshold being considered as triggering a reporting duty) and those for more, found that in $46 \%$ of the claims settled for less than $\$ 30,000$ the doctor had failed to meet the required standard of care. ${ }^{92}$

Relying on a claims-paid standard, however, has at least two drawbacks. First, cases often lack malpractice merit, and therefore may result in no payment, not because of an absence of error on the lawyer's part, but because of a difficulty in showing causation or damages. Yet, it is the lawyer's errors themselves that are potentially relevant to disciplinary authorities. Second, there is a substantial lag between the time the claim against the lawyer is made and the time it is resolved. ${ }^{93}$ This is only compounded by the sometimes lengthy delay between the alleged act of malpractice, the client's discovery of it, and the subsequent decision to pursue a claim. If the goal is to identify patterns of substandard practice so as to intervene in a timely way with remedial assistance,

categorizing these dispositions than does the ABA, which might explain some of the difference. For a discussion of why plaintiffs abandon malpractice claims in the medical malpractice context, see Dwight Golann, Dropped Medical Malpractice Claims: Their Surprising Frequency, Apparent Causes, and Potential Remedies, 30 HEALTH AfF. 1343, 1346-47(2011).

91 See, e.g., Berenson, supra note 80 , at 684 (suggesting that the public should be informed of lawyer malpractice payments above $\$ 5000$ as a "fair number" below which settlements might well be for "nuisance value"). National lawyer malpractice data suggest that almost $75 \%$ of all cases result in expense and indemnity/settlement payments of $\$ 10,000$ or less. Profile of Legal MALPRACTICE Claims, supra note 72, at 14 tbl.8. Using that as a cut-off would certainly make the number of required reports more manageable. For a general study of the pros and cons of setting a monetary threshold before which claims need be reported, see U.S. Gov'T ACCOUNTABILITY OfFICE, GAO/IMTEC-92-56, PraCTITIONER DATA BANK: INFORMATION ON SMAll MEDiCAL MALPRACTICE PAYMENTS (1992) [hereinafter GAO, SMALL MEDICAL MALPRACTICE PAYMENTS], available at http://www.gao.gov/assets/220/216480.pdf. See also NPDB, MALPRACTICE REPORTING REQUIREMENTS, supra note 81 , at 5-7.

92 GaO, SMAll Medical Malpractice Payments, supra note 91 , at 10 . Another study found that doctors who had resolved malpractice claims for less than $\$ 30,000$ were still twice as likely to have future malpractice claims brought against them than were those who had not had any claims filed against them. $I d$.

${ }^{93} \mathrm{Cf}$. Profile Of Legal Malpractice Claims, supra note 72 , at 15 tbl.9 (reporting that in more than $44 \%$ of the cases it took two or more years between notice of error made to the insurer and the closing of the file on the matter); see also U.S. GOV'T ACCOUNTABILITY OfFice, GAO-01-130, National Practitioner Data Bank: Major Improvements ARE NEEDED TO ENHANCE DATA BANK's RELIABILITY 19 (2000) [hereinafter GAO, NPDB IMPROVEMENTS] (noting in the medical context an average four and one-half year gap between instances of alleged malpractice and their resolution). 
or discipline if warranted, such delay may allow additional misconduct to occur unabated. ${ }^{94}$

Requiring all claims made by clients to be reported would ameliorate those problems to some extent, but may cause problems of its own. First, the volume of reports would rise, imposing increased costs on insurers for reporting and on disciplinary agencies in processing and evaluating those reports. ${ }^{95}$ It is likely that the number of reports would more than double. ${ }^{96}$ Yet these increased costs may not be offset by a corresponding benefit from the reporting. At the claimsfiled stage, many of the claims are likely to be of little merit. ${ }^{97}$ If claims-made reporting is preferable, but the costs seem too great, reporting might be limited to instances in which a set number of claims are made against a lawyer in a calendar period. ${ }^{98}$

\section{B. Burden of Compliance on Reporting Entity and Others}

Adopting a reporting duty will impose costs. At a minimum there will be compliance costs for the insurers. The extent depends on how detailed the reports must be ${ }^{99}$ and how many reports. will be required. ${ }^{100}$ There is also a

${ }^{94}$ To avoid this, one could set as a trigger the date on which the lawyer reports the incident to the insurer, a reporting duty imposed under many insurance policies. 5 MALLEN \& SMITH, supra note $72, \S 37: 17$, at $128-30$. However, there is a chance that a requirement on insurers to notify disciplinary authorities of this fact might deter lawyers from reporting incidents to insurers. Ronald E. MALLEN, Legal MALPRACTICE: THE LAW OfFiCE GuidE TO Purchasing Legal Malpractice Insurance $\$ 9: 29$ (2011 ed.). This, in turn, would postpone, if not preclude, the insurer's attempts at claim repair. Given that a high number of claims are resolved by repair, this potential consequence outweighs the benefit of incidentnotification to disciplinary authorities. See 2010 OREGON REPORT, supra note 88, at 4 (finding that $19 \%$ were repaired in Oregon from January 1 to December 31,2010 ).

${ }^{95}$ See generally infra Part III.B.

96 See, e.g., Profile of Legal MALPRACTICE Claims, supra note 72, at 9 tbl.4. In the five periods studied from 1985 to 2007 , the percentage of claims filed and resolved without payment, which would be required to be reported under the claims-made standard, but not the claims-paid standard, ranged from $56.36 \%$ to $70.88 \%$ of the total number of claims made. Id.

97 See supra text accompanying note 81 .

${ }^{98}$ Cf. CAL. BUS. \& PROF. CODE $\S 6068(0)(1)$ (West $2003 \&$ Supp. 2012) (requiring every lawyer, whether or not insured, to report " $[t]$ he filing of three or more lawsuits in a 12 month period against the attorney for malpractice or other wrongful conduct committed in a professional capacity"). That multiple claims information is significant is reflected in the fact that malpractice insurers treat multiple claims as a red flag in deciding on whether to provide coverage and the cost of that coverage. See, e.g., Managing Risk: What Law Firms Must Do to Control Liability Insurance Costs, LAW OFF. MGMT. \& ADMIN. REP., May 2003, at 1,11 (noting that insurers treat two or more claims within the past year or three or more claims within ten years as red flags).

${ }^{99}$ Estimates of the average time it takes to fill out the online form for reporting closed claims in Florida vary. Compare Telephone Interview with Carol Coady, Fla. Lawyers Mut. Ins. Co. (Aug. 2, 2011) (estimating her average time for the form's completion as three minutes), with Telephone Interview with Lorren E. Beneke, Cont'l Cas. Co. (Aug. 3, 2011) 
cost-shifting aspect to this issue. The more detail required in the report, the higher the cost to the insurer, but, up to a point, the greater the detail, the greater the utility of the information to disciplinary authorities, which, in turn, lessens their investigative costs. To the extent these reports lead to disciplinary actions, malpractice insurers may incur additional costs in defending these actions. ${ }^{101}$ At the extremes, these costs might induce some insurers, particularly in smaller markets, to abandon the market rather than incur the reporting costs. ${ }^{102}$

(estimating his average time for the form's completion as ten to fifteen minutes). Cf. NPDB, MALPRACTICE REPORTING REQUIREMENTS, supra note 81, at 3 (estimating that it took insurers approximately eighty minutes per report to compile and report to the National Practitioner Data Bank malpractice claims paid).

${ }^{100}$ In California, which requires malpractice insurers to report within thirty days of receipt of any claims or actions for damages against a member of the State Bar of California they cover for fraud, misrepresentation, breach of fiduciary duty, or negligence committed in a professional capacity, insurers' reports per year steadily declined over a six-year period, but have risen somewhat in recent years: 2003 (368), 2004 (214), 2005 (153), 2006 (152), 2007 (105), 2008 (103), 2009 (139), 2010 (140). 2010 CALIFORNIA ATTORNEY DISCIPLINE REPORT, supra note 50, at 44; 2009 CALIFORNIA DISCIPLINE SYSTEM REPORT, supra note 50, at 6; State BaR of CAL., 2008 RePORT ON THE STATe BaR of CALIFORNIa Discipline SYSTEM 5 (2009) [hereinafter 2008 CALIFORNIA DISCIPLINE SYSTEM REPORT], available at http://www.calbar.ca.gov/LinkClick.aspx?fileticket $=9 \mathrm{~N} 0 \mathrm{ezcHZcu} 8 \% 3 \mathrm{D} \&$ tabid $=224 \& \mathrm{mid}=1$ 534; State Bar of CAL., 2007 Report on the STATE Bar of CaliforNia Discipline SYSTEM 5 (2008) [hereinafter 2007 CALIFORNIA DISCIPLINE SYSTEM REPORT], available at

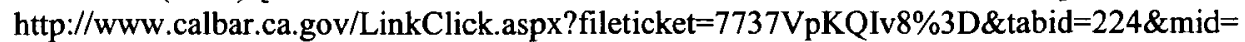
1534. In Florida, which requires malpractice insurers to report claims paid and claims involving loss adjustment expenses in excess of $\$ 5000$, the number of filings has ranged from 132 to 290 for the years 2005 through 2010. See Professional Liability Claims Reporting, FLA. OFF. OF INS. REG., https://apps.fldfs.com/PLCR/Search/LPLClaim.aspx (last visited Mar. 9, 2012). Due to compliance issues, these figures are probably understated. See infra Part III.C.

101 See, e.g., Brian S. Faughnan, A Silver Lining for Your Gray Cloud? Malpractice Policy Coverage for Disciplinary Defense Costs, TENN. B.J., July 2009, at 20, 21 (noting that "many malpractice insurance policies contain a supplemental payment provision for the defense of disciplinary proceedings"); Alvin 1. Frederick, How to Cope with Maryland's New Attorney Discipline Rules, MD. B.J., July-Aug. 2001, at 42, 45 (noting that lawyer malpractice policies increasingly cover disciplinary actions).

${ }^{102}$ See James W. St Clair, Those Monstrous Malpractice Premiums, LEGAL ECON., Sept. 1987, at 24, 26 (In April 1986, insurance carriers cancelled all malpractice policies for West Virginia lawyers in protest of the state's new mandatory reporting law, which, they argued, would harm their competitiveness and profit margins. In response, the law was repealed.); $c f$. Dwain E. Fagerlund, Note, Legal Malpractice: The Locality Rule and Other Limitations of the Standard of Care: Should Rural and Metropolitan Lawyers Be Held to the Same Standard of Care?, 64 N.D. L. REV. 661, 698 n.247 (1988) (postulating that North Dakota did not go after insurance companies for underreporting lawyer malpractice claims to the state insurance commissioner, as they were required to do by statute, because of a fear that that would drive insurers from the state). 


\section{Potential Compliance Problems}

As with overdraft notification, the system will work more smoothly if the reporting duty is clearly defined. Because lawyers can be subjected to civil liability in a myriad of ways, ${ }^{103}$ and terms like "legal malpractice" are subject to multiple definitions, ${ }^{104}$ I would simply require malpractice insurers to report on any matters for which they provide coverage. ${ }^{105}$ If the matter falls within the policy and the designated reporting trigger occurs, reporting would be required. To the extent the matter falls outside of coverage, such as a criminal act, reporting would not be required. That is not because disciplinary authorities are uninterested in the conduct, but simply to make the insurer's reporting duty manageable. ${ }^{106}$ These other sorts of misconduct can be captured by courtreporting ${ }^{107}$ or self-reporting ${ }^{108}$ requirements.

Even with a clear definition, compliance problems may arise. ${ }^{109}$ Whether through ignorance, or a conscious decision either to avoid compliance costs, or

103 See generally MALLEN \& SMITH, supra note 72, at xxi-xxiii (taking four of its five volumes to describe the potential professional liabilities of lawyers).

${ }^{104} I d$. $§ 1: 1$, at $2-11$.

105 See generally MALLEN, supra note 94, $\S 2: 21-: 25,2: 42-: 55$ (discussing typical coverage and exclusions in legal malpractice policies). For those that are self-insured, one would need to provide a different definition. California imposes a number of different reporting standards on lawyers that might be looked to in drafting such a standard. See infra notes 305-12.

106 It may also seem unfair to require the insurance company to bear the costs of reporting for uncovered matters. If we pick a claims-resolved-for-damages approach, rather than a claims-made approach, this latter problem goes away from the insurer's perspective.

107 See infra Part IV.

108 See infra Part V.

${ }^{109}$ See Ramos, Dirty Little Secret, supra note 72, at 1667-68 (concluding, after comparing the data revealed from mandatory reporting in Florida and California with other sources, that "full compliance with the mandatory reporting laws appears to have been a major problem"); Ramos, No Lawyer or Client Is Safe, supra note 72, at 20 (noting that at that time (1993), as many as $50 \%$ of the insurance claims carriers that were required to report in Florida had not been). Indeed, the current figures for Florida and California still appear deceptively low. For example, Continental Casualty Company, a major attorney malpractice carrier in Florida, has no closed-claim reports listed on the Florida Office of Insurance website since 2009. See Professional Liability Claims Reporting, FLA. OFF. OF INS. REG., https://apps.fldfs.com/PLCR/Search/LPLClaim.aspx (last visited Mar. 9, 2012).

Compliance problems have also arisen with respect to the mandatory reporting of medical malpractice and other adverse actions to the National Practitioner Data Bank, but those have largely concerned reporting by hospitals and managed-care institutions rather than by malpractice insurers. See, e.g., OFFICE OF THE INSPECTOR GEN., DEP'T OF HEALTH \& HuMAN SERVS., OEI-01-99-00690, MANAGED CARE ORGANIZATION NONREPORTING TO THE NATIONAL PRACTITIONER DATA BANK (2001), available at http://oig.hhs.gov/oei/reports/oei01-99-00690.pdf; GAO, NPDB IMPROVEMENTS, supra note 93, at 4, 10 (finding that malpractice underreporting is less of an issue than underreporting of clinical privilege restrictions by hospitals and other health care providers). Some noncompliance by insurers clearly occurs, but it has not been quantified. See id. at 10-13. 
to curry favor with lawyer customers, some insurers may fail to report. For those who are self-insured, a short-term perceived self-interest may make this even more likely. ${ }^{110}$

While compliance problems are possible, I believe they will be low. First, legal malpractice insurance is a sophisticated niche industry that requires licensing by the states. The duty to report, once adopted, is likely to be known to the insurers. Education campaigns, prods on annual registration forms, and the like can serve as reminders.

A conscious decision to circumvent the rules might be more likely were the consequences of reporting too great. For example, reporting doctor malpractice information to the National Practitioner Data Bank, which hospitals are required by law to access when extending staff privileges and at intervals thereafter, ${ }^{111}$ can have substantial repercussions for the doctors involved. ${ }^{12}$ Since hospitals run the risk of civil liability for negligent credentialing, they err on the side of caution before credentialing doctors with "a record." 13 Such reports may also affect a doctor's ability to secure malpractice insurance or at least affect the rate. ${ }^{114}$ To the extent reporting leads to public revelation of the underlying conduct, as it does in some systems, that has reputational costs as well. ${ }^{115}$ Insurers driven by friendship with particular clients, or the desire to keep a client happy for business reasons, have some incentive to avoid reporting.

In the system I envision, those incentives are weaker. I do not contemplate public revelation of reported data about individual lawyers unless the conduct ultimately results in a disciplinary proceeding. ${ }^{116}$ And, as with each of the

110 See infra text accompanying note 121.

111 See 42 U.S.C. $\$ 11135$ (a) (2006).

112 Florence Yee, Note, Mandatory Mediation: The Extra Dose Needed to Cure the Medical Malpractice Crisis, 7 CARDOZO J. CONFLICT ReSOL. 393, 430 (2006) (noting that "[d]octors fear reported settlement information can directly or indirectly negatively impact their ability to maintain good standing with their malpractice carriers, providers, peers, and patients, and may even jeopardize hospital staff privileges and medical board status").

113 See generally AMY E. WATKINS, NEgLIGENT CREDENTIALING LAWSUITS: STRATEGIES TO PROTECT YOUR ORGANIZATION (2005).

114 See Maves, supra note 80 , at 2.

115 See William M. Sage et al., Bridging the Relational-Regulatory Gap: A Pragmatic Information Policy for Patient Safety and Medical Malpractice, 59 VAND. L. REV. 1263, 1288 (2006) (noting that states often make public doctor-specific information on medical malpractice judgments, including a few that disclose malpractice settlements as well). In Florida, the Florida Office of Insurance Regulation makes information pertaining to closed claims against lawyers resulting in payment by settlement or judgment available to the public. See Professional Liability Claims Reporting, FLA. OFF. OF INS. REG., https://apps. fldfs.com/PLCR/Search/LPLClaim.aspx (last visited Mar. 9, 2012).

116 This comports with modern practice in the vast majority of jurisdictions. At present, most states keep confidential lawyer-specific complaints and investigations until a finding of probable cause or the filing of a formal complaint. See Mark L. Harrison, Public Access to Attorney Proceedings and Records 1 (Aug. 1, 2009) (unpublished paper distributed at the Association of Professional Responsibility Lawyers (APRL) Annual Meeting), available at http://www.aprl.net/members/meeting_archive/downloads/2009-Chicago/10a_PublicAccess 
automatic reporting devices I propose, there is no presumption that the reported act will lead to disciplinary action. It is simply to build a file that may or may not ultimately trigger some action. Nor do I envision allowing any third-party access to the information, whether to inform hiring decisions or for other reasons. ${ }^{117}$

To the extent noncompliance fears remain, a penalty provision could be added to the system, ranging from a small monetary penalty ${ }^{118}$ to a prohibition against providing insurance in the state. 119 And even without perfect compliance, partial compliance will add substantial information to the disciplinary system. ${ }^{120}$

\section{Indirect Consequences}

One hidden cost, or at least impact, of the reporting rule is its potential effect on the primary conduct of lawyers and those seeking redress from lawyers for their alleged injuries.

From the lawyers' perspective, some may choose to go without coverage if they fear that insurers will report them to disciplinary authorities when claims arise. ${ }^{121}$ Even if a self-reporting duty also were imposed, a lawyer might still want control over whether to report or to flout the system.

ForAPRLProgram.pdf (login required). Eleven states go even further and maintain confidentiality until the imposition of public discipline. Id. Only four require public access at an earlier time. Id.; see also Levin, supra note 14, at $19 \mathrm{n} .122$ (describing these broader public access provisions). That is not to suggest, however, that there have not been calls for greater openness in the disciplinary process. See, e.g., id. at 29-49; cf. John P. Sahl, Secret Discipline in the Federal Courts-Democratic Values and Judicial Integrity at Stake, 70 NOTRE DAME L. REV. 193, 250-51 (1994) (asserting that the entire complaint process regarding federal judges should be open for public review).

117 That is not to suggest that there will be full compliance with the reporting requirement, only that the disincentives for reporting are fewer. See supra text accompanying note 109 (underreporting by lawyer malpractice insurers).

118 See, e.g., FLA. STAT. ANN. \$ 627.912(4) (West 2011) (allowing the Florida Office of Insurance Regulation to impose a $\$ 250$ /day fine, up to $\$ 1000$ per case, against lawyer professional liability insurers in violation of the reporting requirement); Ramos, Dirty Little Secret, supra note 72, at 1666-69, 1726 (pointing out substantial underreporting by insurers in Florida and elsewhere, but endorsing the Florida approach if the requirement is "strictly enforced"). But cf. GAO, NPDB IMPROVEMENTS, supra note 93, at 10-11 (reporting that although penalty provisions exist for failure to report medical malpractice payments to the National Practitioner Data Bank, the Government has been reluctant to impose them because the cost to pursue them often exceeds their value).

${ }^{119} \mathrm{Cf}$. supra text accompanying note 61 (discussing the use of such an incentive to encourage banks to follow their duty to report lawyer overdrafts on trust accounts).

120 See supra note 100 (describing the number of filings yearly under the California and Florida malpractice reporting requirements).

121 The degree to which lawyers presently obtain malpractice insurance is unclear. See Fischer, supra note 79, at 90 (describing the question of the percentage of lawyers who carry malpractice insurance as "one of the profession's mysteries"); Jeffrey D. Watters, What They 
For lawyers who do maintain malpractice coverage, a reporting duty on insurers may make lawyers less likely to make claims under their insurance policies. ${ }^{122}$ The decision not to notify the insurer of the underlying incident, however, may itself be a breach of the insurance policy. ${ }^{123}$ At the least, the choice would force the lawyer to forgo insurance protection on the claim. ${ }^{124}$

The experience of the medical community, in a system in which malpractice claims paid must be reported to the National Practitioner Data Bank, is that the reporting duty affects settlement behavior. Settlement is no longer simply: an economic decision weighing the cost of litigation and the possible outcomes should the case go to trial, but rather has career implications for the physician as well. ${ }^{125}$ This can lead to a schism between doctors and insurance companies

Don't Know Can Hurt Them: Why Clients Should Know if Their Attorney Does Not Carry Malpractice Insurance, 62 BAYLOR L. REV. 245, 250 (2010) (noting "the paucity of information regarding how many attorneys actually do not carry malpractice insurance"). However, recent studies conducted in a few states provide some guidance. In California, it is estimated that approximately $20 \%$ of the lawyers are uninsured. INS. DISCLOSURE TASK FORCE, STATE BAR OF CAL., FINAL REPORT AND RECOMMENDATIONS 11 (2007), available at http://calbar.ca.gov/portals/0/documents/publiccomment/2008/insurance-dis_BOG-

Sept14.pdf. In Utah, $26 \%$ of the lawyers representing private clients were found to be uninsured. See V. Lowry Snow, Professionally Insured. . . To Be or Not to Be, UTAH B.J., Nov.-Dec. 2007, at 6, 6 (citing a study done by the Utah bar). In Texas, the estimated number of uninsured lawyers in private practice is $36 \%$ according to a bar survey, but some have estimated the number to be in excess of $60 \%$. Mary Alice Robbins, Bar Task Force Studies Insurance Disclosure Rule, TEX. LAW., Nov. 19, 2007, available at http://www.law.com/jsp/article. jsp?id=1202435484624; see also Fischer, supra note 79, at $64 \mathrm{n} .23,91$ (presenting similar data from other jurisdictions). The Utah study found that the likelihood of carrying malpractice insurance declines with the size of the firm in which the lawyer is employed. See Snow, supra, at 6 . In firms of eleven or more lawyers, $99 \%$ of the lawyers had coverage; in firms from two to ten lawyers, $82 \%$ had coverage; for solo practitioners, only $38 \%$ had coverage. Id. Only Oregon requires malpractice coverage, although an increasing number of states require lawyers to disclose to clients, directly or indirectly, when they do not have coverage up to a certain amount. See Standing Comm. on Client Prot., State Implementation of ABA Model Court Rule on Insurance Disclosure, A.B.A. (Apr. 25, 2011), http://www. americanbar.org/content/dam/aba/migrated/2011_build/ professional_responsibility/malprac_disc_chart.authcheckdam.pdf (identifying twenty-four states with some sort of disclosure requirement).

122 MALLEN, supra note $94, \S 9: 29$ (noting that lawyers, in assessing the consequences of making a report to their insurers, should take into account the fact that the act may trigger for the insurer a reporting requirement to disciplinary authorities); cf. id. $\$ \S 2: 33,9: 27$ (noting that lawyers, fearing that reporting a claim to their insurer may affect their insurance renewal or premiums, often delay reporting claims to their insurers in the hope that they can resolve the matters on their own). See generally Ramos, No Lawyer or Client Is Safe, supra note 72 , at 15 (noting that lawyers sometimes "gamble" and fail to tell insurers of instances of potential malpractice).

123 See 5 MALLEN \& SMITH, supra note $72, \S 37: 18$.

${ }^{124}$ See MALLEN, supra note 94 , $\$ 9: 25$ (failure to report may deprive attorney of coverage).

125 See supra text accompanying notes 111-15. 
over whether to settle certain claims, as settlement has additional costs for doctors that the insurers do not bear. ${ }^{126}$

There is also pressure to structure settlements in ways that avoid the reporting duty. In the medical setting, plaintiffs typically sue both the hospital and the medical team for malpractice. It is common when structuring a settlement of such claims to drop the doctors and recover only against the hospital. This is done, in part, in response to the reporting system for the National Practitioner Data Bank, in which monetary settlements against a doctor must be reported and become part of the doctor's file, whereas entity-based settlements do not. ${ }^{127}$ In reporting systems that set a monetary floor for the malpractice settlements that need to be reported, there is pressure for settlements to be secured below that floor to avoid the need to report. ${ }^{128}$

Depending on how the reporting scheme is structured, the additional consequences associated with malpractice claims may increase the claimant's leverage. Suppose, for example, that a written demand needs to be filed against a lawyer before an insurer must report a claim. ${ }^{129}$ That would create pressure on lawyers and their insurers to resolve matters before written demands are made. If the system only requires reporting claims settled or resolved above a certain monetary value, cases may settle under the floor even if their merit is questionable. ${ }^{130}$

${ }^{126}$ See William M. Sage, Medical Malpractice Insurance and the Emperor's Clothes, 54 DEPAUL L. REV. 463, 465 n.12 (2005) ("The most pronounced conflict [between doctors and their insurers] has been over the right to settle without the physician's consent, mainly because settlements must be reported to the National Practitioner Data Bank."); National Practitioner Data Bank, AM. MED. Ass'N, http://www.ama-assn.org/ama/pub/physicianresources/legal-topics/business-management-topics/national-practitioner-data-bank.shtml (last visited Mar. 9, 2012) (cautioning doctors that, given the repercussions of reporting, they should be careful of settling even nuisance claims). But cf. Public Access to the NPDB: Hearing on What Consumers Should Know, supra note 80, at 63 (noting that in many instances doctors cannot control whether to settle).

${ }^{127}$ See Public Access to the NPDB: Hearing on Assessing Operation, supra note 80, at 120; Public Access to the NPDB: Hearing on What Consumers Should Know, supra note 80, at 21, 23; GAO, NPDB IMPROVEMENTS, supra note 93, at 11 (discussing this "corporate shield" loophole in the reporting system).

${ }^{128} \mathrm{GAO}$, Small Medical Malpractice Payments, supra note 91, at 10-11 (noting that states requiring reporting of medical malpractice claims above a threshold have many claims settled just below that threshold); NPDB, MALPRACTICE REPORTING REQUIREMENTS, supra note 81 , at 7 .

${ }^{129}$ See, e.g., FLA. STAT. ANN. § 627.912(1)(a) (West 2011) (requiring those who insure members of the Florida Bar to report to the Florida Department of Insurance "any written claim or action for damages for personal injuries claimed to have been caused by error, omission, or negligence in the performance of such insured's professional services" if the claim resulted in a final judgment and the appeal has expired, or was settled in any amount (emphasis added)).

${ }^{130}$ See generally supra note 128 . 


\section{E. Recommendation}

Unlike overdraft reporting, insurer reporting of lawyer malpractice information is uncommon. As such, there is less of a track record to consult to determine if the information that would be provided is worth the costs and potential unintended consequences involved. Assessing that question becomes even more difficult because there is no consensus on what actions should trigger reporting, and as discussed previously, that choice has implications on both the cost and benefit sides. ${ }^{131}$ Further, imposing a burden of this kind on insurers is different in kind from overdraft reporting. In the latter case, banks already are reporting overdrafts to customers, so the additional burden of also informing disciplinary authorities is slight. Here a new, independent burden is being placed on the reporter.

That said, I would recommend expansion of this requirement, subject to a possible reassessment after wider experience is gained. I would recommend that insurers, with analogous self-reporting required on those uninsured, report either claims made or claims paid depending on each state's evaluation of the likely relevance of the information and resource constraints. ${ }^{132}$ Such reporting is common in the medical field and that experience suggests it might be helpful in the legal field as well.

While both the direct and indirect costs of reporting malpractice data need to be considered, ${ }^{133}$ their impact should not be overblown. The private nature of the disclosure to disciplinary authorities ${ }^{134}$ and its use as only another piece of datum in a file ${ }^{135}$ should encourage compliance with the reporting requirement and lessen the incentives to engage in strategic behavior to avoid it.

\section{REPORTING By Those INVOLVED IN THE JUdiCIAL PROCESS}

While most states impose an individual obligation on lawyers and judges to report certain lawyer misconduct they observe, ${ }^{136}$ beyond the reporting of lawyer involvement in criminal activities, few place systemic obligations on those in the court system to report the occurrence of particular acts to disciplinary authorities. The most extensive set of requirements for such reporting is found in California, and I will use that set as the focal point for analyzing this form of automatic reporting.

In California, a court must notify the State Bar of:

131 See supra Parts III.A-B.

132 If a claims-made approach is taken, I would limit reporting to claims falling within the insurance coverage. See supra text accompanying notes 103-08.

${ }^{133}$ See supra Part III.B (discussing direct costs); supra Part III.C (discussing indirect costs).

134 See supra text accompanying notes 116-17.

135 See generally supra text accompanying notes 76-80.

${ }^{136}$ See supra text accompanying notes 5-9. 
- a final order of contempt entered against a lawyer involving grounds warranting professional discipline; 137

- modification or reversal of a judgment in a judicial proceeding based in whole or in part on the misconduct, incompetent representation, or willful misrepresentation of an attorney; 138

- imposition of any judicial sanctions against an attorney of $\$ 1000$ or more, except sanctions for failure to make discovery; ${ }^{139}$ and

${ }^{137}$ CAL. BuS. \& Prof. Code $\$ 6086.7$ (a)(1) (West Supp. 2012); see, e.g., In re Koven, 35 Cal. Rptr. 3d 917, 928 (Ct. App. 2005) (applying this provision).

${ }^{138}$ CAL. BuS. \& Prof. CODE $\S 6086.7$ (a)(2); see, e.g., Hernandez v. Paicius, 134 Cal. Rptr. 2d 756, 767 (Ct. App. 2003) (ordering clerk of the court to report pursuant to this provision).

Others endorse the idea that prosecutorial misconduct encompassed by a provision such as this should be reported by courts to disciplinary authorities. See, e.g., CCFAJ REPORT, supra note 14, at 70-72; KATHLEEN M. RidOLFI \& MAURICE POSSLEY, PREVENTABLE ERROR: A REPORT ON PROSECUTORIAL MISCONDUCT IN CALIFORNIA 1997-2009, at 79-80 (2010); John F. Terzano et al., Improving Prosecutorial Accountability: A Policy Review, JUST. PROJECT, 10-12 (2009), http://amlawdaily.typepad.com/JusticeProjectReport.pdf [hereinafter THE JUSTICE PROJECT] (recommendation 4). So, too, has the reporting of criminal defense counsel misconduct. See, e.g., CCFAJ REPORT, supra note 14, at 72-73; Meredith J. Duncan, The (So-Called) Liability of Criminal Defense Attorneys: A System in Need of Reform, 2002 BYU L. REV. 1, 45-46 (describing the degree of criminal defense counsel error and suggesting more of it be policed by the bar through automatic reporting of ineffective assistance of counsel and criminal malpractice claims).

${ }^{139}$ CAL. BuS. \& Prof. Code $\S 6086.7$ (a)(3); see, e.g., DeRose v. Heurlin, 122 Cal. Rptr. $2 d 630,648$ (Ct. App. 2002) (court ordering clerk of the court to report pursuant to this provision (formerly $\S 6086.7(\mathrm{c})$ )).

The automatic reporting of certain judicial sanctions by court officials to disciplinary authorities is unusual but not unheard of. Several courts have imposed a similar duty by local rule. See, e.g., D. MD. R. 602 (providing for the fining of attorneys who fail to appear, are late for a proceeding, or fail to file a timely status report, and requiring referral to disciplinary counsel if more than two such fines have been imposed on an attorney in a fiveyear period); N.D. \& S.D. MISS. CIV. R. 83.1(c)(1) (requiring clerk of courts to report the revocation or suspension of a lawyer's admission to practice before the court to disciplinary authorities of the states in which the lawyer is licensed); D. NEV. R. 10-7(d) (requiring reporting to Nevada disciplinary authorities, among others, of any lawyer disciplinary order of the court); E.D. TEX. CIV. R. AT-2(e) (requiring reporting to Texas disciplinary authorities, among others, any final disciplinary action by the court).

Further, reporting of this sort has been suggested by various commentators. The most common suggestions call for the required reporting of Rule 11 sanctions to disciplinary authorities, although they vary on the precise mechanisms for doing so. See, e.g., Jeffrey A. Parness, Disciplinary Referrals Under New Federal Civil Rule 11, 61 TENN. L. REV. 37, 50 (1993) (citing comments by Professor Leubsdorf advocating court reporting of Rule 11 sanctions to a national registry available to disciplinary counsel, and by Professor Kramer advocating that federal district courts adopt local rules mandating the reporting of Rule 11 sanctions to disciplinary authorities); $c f$. Brown, supra note 5, at 1606-13 (recommending that lawyers be required to report their service of Rule 11 motions on other parties to a national litigation misconduct database that could be accessed by disciplinary authorities); id. at $1561 \mathrm{n} .17$ (suggesting the idea could be expanded to other forms of litigation 
- imposition of any civil penalty upon an attorney for violating a state statute involving giving notice to Indian tribes with respect to voluntary placements of Indian children. ${ }^{140}$

California courts also must notify the state bar of certain adverse decisions against lawyers in both civil and criminal matters. On the civil side, a court must report the entrance of any judgment for damages in any "civil action for fraud, misrepresentation, breach of fiduciary duty, or gross negligence committed in a professional capacity." 141 On the criminal side, the clerk of the court must report to the state bar the conviction of any crime by a lawyer. ${ }^{142}$

Much of the conduct courts are required to report in a system like California's might already be encompassed by the reporting provision in a state's code of judicial conduct. Nevertheless, having a delineated list of occurrences that are automatically to be reported offers several advantages.

Some states have adopted judicial conduct provisions modeled on the ABA's 1972 Model Code of Judicial Conduct, which requires only that judges "take appropriate action" in the face of lawyer violations of the applicable professional conduct rules, of which reporting to disciplinary authorities is but one option. ${ }^{143}$ In a system like California's, that discretion on how to handle certain misconduct is constrained by an automatic reporting system. The activity encompassed by the duty must be reported.

Other states have adopted standards that mirror the ABA's subsequent revisions of the Model Code of Judicial Conduct. As revised, reporting is

misconduct, such as discovery abuse or the discriminatory use of peremptory challenges, as well). Others have questioned the necessity for such reporting. See, e.g., Joy, supra note 8, at 806-15 (describing, with approval, the informal institutional choice of the present system to allocate the policing of Rule 11 misconduct to judges largely out of the purview of the disciplinary process); Stephen R. Ripps \& John N. Drowatzky, Federal Rule 11: Are the Federal District Courts Usurping the Disciplinary Function of the Bar?, 32 VAL. U. L. REV. 67, 86-88 (1997) (reporting on results of survey of federal judges and state disciplinary officials). While some judges and disciplinary authorities favored automatic reporting of Rule 11 violations, the majority of both groups did not, although the prospect was more favorably received by disciplinary officials than by judges). Id.

140 CAL. BUS. \& PROF. CODE $\S 6086.7$ (a)(4) (West Supp. 2012) (referencing $\S 8620$ of the California Family Code).

141 CAL. BuS. \& PROF. CODE $\S 6086.8$ (a) (West 2003).

142 Id. $\$ 6101(\mathrm{c})$. Such reporting has been endorsed by the ABA MODEL RULES FOR LAWYER DISCIPLINARY ENFORCEMENT R. 19(A) (2002). Many other states also require courts to report attorney criminal convictions. Variations arise in a number of areas, including which criminal convictions trigger the reporting requirement. Compare PA. R. DISCIPLINARY ENFORCEMENT 214(b) (requiring clerk of court to report conviction of any crime to disciplinary authorities), with MINN. R. LAWYERS PROF. RESPONSIBILITY 17(a) (requiring court administrator to report felony convictions), MONT. CODE ANN. § 37-61-302 (2011) (requiring reporting of felonies or misdemeanors involving "moral turpitude"), and UTAH CODE JUD. ADMIN. R. 14-519(a) (requiring reporting of "any felony or any misdemeanor which reflects adversely on the lawyer's honesty, trustworthiness or fitness as a lawyer").

143 Model Code of Judicial Conduct Canon 3(B)(3) (1972). 
required only when the judge has "knowledge that a lawyer has committed a violation of the Rules of Professional Conduct that raises a substantial question [as to] the lawyer's honesty, trustworthiness, or fitness as a lawyer in other respects." 144 In a system like California's, the individualized judicial decision on whether certain misconduct rises to this level is curtailed. No such weighing is required; listed activities must be reported. Curtailing discretion in this manner clearly signals activity that disciplinary authorities want in their files and provides judges some cover from the negative consequences of reporting. Reporting ceases to be a voluntary hostile act and becomes an unavoidable necessity. 145

In addition to reporting by the court or the court clerk, state prosecutors also are required to report to the state bar "the pendency of an action against an attorney charging a felony or misdemeanor immediately upon obtaining information that the defendant is an attorney."146 In addition, the prosecutor must inform the clerk of courts that the defendant is an attorney, and the clerk is to record that fact "prominently" in the file, presumably to put the clerk on notice to report if a conviction is ultimately entered.147 In some states,

${ }^{144}$ Id. R. 2.15(B) (2007); see also id. Canon 3(D)(2) (1990).

145 See Greenbaum, Judicial Reporting, supra note 4, at 553-54.

146 CAL. Bus. \& Prof. CODE $§ 6101(\mathrm{~b}) ;$ see also Fla. R. Regulating Fla. Bar 3-7.2(e) (requiring state's attorneys to report indictment or information of a Florida bar member, where that affiliation is known, to Florida disciplinary authorities). In some states, information about the initiation of a criminal action against an attorney is to be sent by the clerk of the court. For example, in South Carolina, the court clerk must notify disciplinary authorities of "any indictment, information or complaint charging a lawyer with a crime." S.C. APP. CT. R. 413(16)(a).

In this area it might be simpler to rely on fingerprint information to trigger reporting. A number of states have adopted processes that gather and retain the fingerprints of specified classes of government employees and licensees, usually as part of background checks preceding initial employment or licensure. See, e.g., CaL. PENAL CODE $\S 11$ 105.2(a) (West 2011); Fla. Stat. ANN. $\$ 943.05(2)(\mathrm{g})$ (West 2011); Mich. COMP. LAWS ANN. $\S 380.1230$ (f) (West 2011); OHIO REV. CODE ANN. $§ 109.5721$ (B) (West Supp. 2011); UTAH CODE ANN. \$53A-6-401(3)(c) (West 2011). Fingerprints taken upon arrest (or other triggering act) are sent to the entity maintaining the retained fingerprints and run for matches. See, e.g., FLA. AdMIN. CODE ANN. r. 11C-4.003 (2011); MICH. CoMP. LAws ANN. $\S 380.1535$ (a)(15); OHIo ReV. CODE ANN. $\S 109.60(\mathrm{~A})(1)-(6)$; $c f$. UTAH CODE ANN. $\S 53 \mathrm{~A}-$ $6-401(3)(c)$. Any matches are then transmitted to the governmental entity that employs or licenses the individual. Costs to maintain this system are usually modest, around five to ten dollars per retained individual. See, e.g., FLA. ADMIN. CODE ANN. r. 11C-6.010(1)-(5); OHIO ADMIN. CODE 109:5-1-03(D) (2011). With respect to licensees, that cost is often assessed to each individual as part of the cost of maintaining a license. Cf., e.g., FLA. STAT. ANN. $\S 943.05(2)(\mathrm{h})(2)$ (noting that costs can be imposed on an individual subject to fingerprint retention); OHIO REv. CODE ANN. $§ 4749.031$ (B) (referencing Ohio Administrative Code $\S 4501: 5-1-21$, which requires that individuals applying for a license pay a fee of twenty-five dollars).

${ }^{147}$ Cal. Bus. \& PROF. Code $§ 6101(b)$. 
prosecutors and defense counsel are required to report attorney criminal convictions to the state disciplinary authorities. ${ }^{148}$

Finally, the clerk of a court that orders involuntary commitment or confinement of a lawyer, or the appointment of a guardian or conservator to handle the lawyer's affairs on account of the lawyer's mental condition, is required to report that to the state bar so the lawyer can be placed on inactive status. ${ }^{149}$

\section{A. Usefulness of the Information to Disciplinary Authorities}

Looked at in the aggregate, reporting here falls into three broad categories. The first involves lawyer misconduct in the judicial process itself. This is reflected in the required reporting of most court sanctions entered against lawyers acting in a professional capacity, including contempt. ${ }^{150}$ On the one hand, reporting here may seem like overkill. By definition, these are instances where a court already has imposed a punishment for the action in question. It is that imposition of punishment that triggers reporting. ${ }^{151}$ On the other hand, it has been repeatedly recognized that judicial sanctions and disciplinary sanctions serve different, but related, functions. ${ }^{152}$ Judicial sanctions are there largely to regulate the case at hand, with a secondary effect of signaling proper behavior to other attorneys. Disciplinary sanctions serve to protect the public as a whole from lawyers who cannot live up to their professional duties. Further, judicial

148 See, e.g., MiCH. CT. R. 9.120(A).

${ }^{149}$ CAL. Bus. \& PROF. CODE $\S 6007$ (a) (West 2003 \& Supp. 2012).

${ }^{150}$ Id. $\S 6086.7(\mathrm{a})(1)-(3)$ (West Supp. 2012).

${ }^{151} \mathrm{Cf}$. Joy, supra note 8, at 814 (explaining the lack of judicial reporting of Rule 11 violations as the product of "an institutional division of authority that recognizes the many advantages judges have over lawyer disciplinary bodies in regulating lawyers' litigation conduct").

152 See STANDARDS FOR IMPOSING LAWYER SANCTIONS preface (1992) (“[T]he lawyer discipline system is in addition to and serves purposes different from contempt powers and other mechanisms available to the judge. Only if all lawyer misconduct is in fact reported to the appropriate disciplinary agency can the legal profession have confidence that consistent sanctions are imposed for similar misconduct."); CTR. FOR PROF'L RESPONSIBILITY \& STANDING COMm. ON PROF'L DisCIPLINE, AM. BAR ASS'N, JUdiCIAL RESPONSE TO LAWYER MISCONDUCT, at II.4-5, V.3 (1984) [hereinafter JUDICIAL RESPONSE TO LAWYER MiSCONDUCT] (stressing the need for judicial reporting in addition to court-imposed sanctions in order to create a central record of repeated misconduct by a particular lawyer); Randall T. Shepard, Essay: What Judges Can Do About Legal Professionalism, 32 WAKE FOREST L. REV. 621, 630 (1997) (noting, in the context of a discussion on judicial reporting of attorney misconduct, that "because private warnings and trial sanctions do not provide sufficient incentives for some attorneys to improve their behavior[,] [s]ometimes only a threat to revoke an attorney's license to practice sends an adequate message"). In fact, the Code of Judicial Conduct was amended in 1990 to strengthen the reporting requirement for judges "to diminish the number of instances in which [they] take it on themselves to impose sanctions for professional misconduct without such reporting." LISA L. MILORD, CTR. FOR Prof'L Responsibility, The DeVelopment of the ABA Judiclal CODE 25 (1992). 
sanctions reflect a need to regulate the moment, whereas reporting such sanctions to disciplinary authorities simply builds a file which may now, or in the future, trigger diversion to training programs or discipline, as appropriate. ${ }^{153}$

To avoid potential system overload, and to maximize the usefulness of the information reported, the California rules refine the information to be reported. For example, not all contempt orders against lawyers must be reported. Only where the underlying conduct involves grounds warranting professional discipline is reporting required. ${ }^{154}$ Further, as to sanction orders, there is both a monetary threshold and a subject matter limitation. Only significant monetary sanctions trigger reporting - the sanction must be $\$ 1000$ or higher. ${ }^{155}$ Small monetary sanctions and all nonmonetary sanctions need not be reported. Presumably the monetary limit serves as a surrogate for the seriousness of the misconduct. Further, discovery sanctions are excluded from the requirement. ${ }^{156}$ I presume that given the rough and tumble of the discovery process, the drafters felt that some breathing room was necessary there. It is important to note that these are just filters for when automatic reporting is required. Judges, or others, remain free to report misconduct underlying lesser sanctions or discovery sanctions if they feel it warranted.

The second category of reportable events ${ }^{157}$ speaks principally to questions of lawyer competence, loyalty, and honesty-all core duties policed by the disciplinary system. ${ }^{158}$ Concerns about gross negligence and incompetent representation go to competence. Breach of fiduciary duty speaks to loyalty. Concerns with fraud and misrepresentation speak to honesty.

Again, the California rules are written with an eye toward the significance of the conduct. Two triggers are at work here. One looks at the consequences of the lawyer's behavior on the client, requiring reporting where the lawyer's conduct leads to modification or reversal of a judgment. ${ }^{159}$ Mere findings of misconduct that do not lead to modification or reversal need not be reported. ${ }^{160}$ Another focuses on situations in which the lawyer's misconduct was sufficiently serious to prompt the filing of a suit that ultimately concludes in the

${ }^{153} \mathrm{Cf}$. NATIONAL ACTION Plan, supra note 18, at 34-35 (stressing the need for judges to report instances of repeated violations of procedural rules by a lawyer, particularly where such misconduct occurs before several judges).

154 CAL. Bus. \& PROF. CODE § 6086.7(a)(1); see In re Aguilar, 97 P.3d 815, 819 (Cal. 2004) (reporting required for contempt order of only one of two lawyers because only one's conduct met the reporting standard).

155 See supra text accompanying note 139.

${ }^{156}$ CAL. BUS. \& PROF. CODE $§ 6086.7$ (a)(3). Some decisions, however, seem to ignore that limitation. See, e.g., Tucker v. Pac. Bell Mobile Servs., 115 Cal. Rptr. 3d 9, 21 (Ct. App. 2010) (directing district court to report discovery sanction to disciplinary authorities if, after recalculating it on remand, the sanction was $\$ 1000$ or more, and relying on $\S 6086.7(\mathrm{a})(3)$ to do so).

${ }^{157}$ CAL. Bus. \& PROF. CODE $\S$ 6086.8(a) (West 2003).

$158 C f$., e.g., RESTATEMENT (THIRD) OF THE LAW GOVERNING LAWYERS $\S 16$ (2000).

159 CAL. BuS. \& PROF. CODE $\S 6086.7$ (a)(2) (West Supp. 2012).

160 See id. 
award of damages against the lawyer. ${ }^{161}$ Voluntary reporting remains available for lawyer behavior that does not set off the triggers. ${ }^{162}$

The third category, which focuses on lawyer criminal activity, ${ }^{163}$ speaks to the character and fitness of the lawyer to represent clients. Such conduct may lead to an interim suspension in the short run and to discipline in its own right as well. ${ }^{164}$ This is an area where it also is common to require lawyer selfreporting. 165

\section{B. Burden of Compliance on Reporting Entity and Others}

In this area, the burden of compliance falls principally on the courts. One cost involved is in monitoring lawyer conduct for possible referral. The more complex the regulatory scheme, the more costly the monitoring. For example, in California, the courts must monitor and report under six different provisions and some of those identify multiple actions that require reporting. ${ }^{166}$

Once a situation requiring a report is identified, the cost of reporting will turn on the degree of information that must be provided. California has developed some very simple one-page forms for the reporting of lawyer professional misconduct and for lawyer criminal convictions. ${ }^{167}$ The use of these forms is not mandatory, however, and courts often convey the information by letter or in other ways. ${ }^{168}$ To the extent a record has been created at the court level with respect. to the lawyer conduct in question, some retrieval and transmittal costs also will be incurred by both the court and the disciplinary authorities.

Another factor to consider is the number of reporting incidents that arise. The greater the number of instances, the higher the cost incurred. Figures for California suggest that the number of required reports will be quite low, although, as discussed in the next section, this may be attributable in part to underreporting by the courts. 169

161 Id. $\S 6086.8$ (a) (West 2003).

162 CAL. CODE JUD. ETHICS Canon 3(D)(2) \& cmt. (2008), available at http://www.courts.ca.gov/documents/ca_code_judicial_ethics.pdf ("Whenever a judge has personal knowledge that a lawyer has violated any provision of the Rules of Professional Conduct, the judge shall take appropriate corrective action[,]" which may include reporting.).

163 CAL. Bus. \& Prof. CODE $\S 6101$ (c) (West 2003).

164 See infra text accompanying notes 263-69.

165 See infra text accompanying notes $232-34,236-45$.

166 See supra text accompanying notes $137-42$.

${ }^{167}$ Discipline Referral Form, STATE BAR OF CAL., http://www.calbar.ca.gov/Link Click.aspx?fileticket=9PqHJKRAF7M\%3d\&tabid=200 (last visited Mar. 9, 2012).

168 Telephone Interview with Cecilia Horton-Billard, Supervising Trial Counsel, State Bar of Cal. (June 3, 2010).

${ }^{169}$ In a state with more than 2000 judicial officers handling almost nine million dispositions a year, reporting has been infrequent. See JUDICIAL COUNCIL OF CAL., 2010 Court STATISTiCs Report: STATEWIDE CASEloAd TrENDS 1999-2000 Through 2008- 
The extent of the cumulative burden on the California courts incurred because of these requirements is unknown, but some have speculated that given the busy nature of the courts, particularly trial courts, reporting "might present a burden to them." 170

\section{Potential Compliance Problems}

In a major study of the criminal justice system in California, compliance problems were uncovered with respect to judicial reporting of prosecutorial and defense misconduct that led to the modification or reversal of a judgment, material required to be reported by state statute. ${ }^{171}$ As a result, "reliance upon the State Bar as the primary disciplinary authority is seriously hampered."172

Several explanations were proffered to explain judicial underreporting. One was that judges might be ignorant of the reporting requirement. ${ }^{173}$ Another was that there was confusion as to who within the court system had the reporting duty. ${ }^{174} \mathrm{~A}$ third explanation was that judges were confused about their reporting duty, since the judicial ethics rules seemed to provide judges more discretion about reporting than the statutory provisions allow. ${ }^{175}$ More generic concerns were the "deep-seated reluctance on the part of trial [and appellate] judges to 'blow the whistle' on lawyers who appear before them[,]" and a potential lack of confidence in the state disciplinary system to which reporting is to be made. ${ }^{176}$ While these problems were identified with respect to but one aspect of the reporting requirement, they are likely to be present throughout. None of these problems, however, are insurmountable.

Judicial ignorance of the reporting requirement can be cured by judicial education. ${ }^{177}$ Anecdotal evidence in California supports that conclusion. ${ }^{178}$

2009, at ix-x (2010) (describing the California judicial system and its workload). The number of mandatory court reports per year from 2004 to 2010 , other than notices of criminal convictions, ranged from 98 to 134 . See 2010 CALIFORNIA ATTORNEY DISCIPLINE REPORT, supra note 50, at 44; 2009 CALIFORNIA DISCIPLINE SYSTEM REPORT, supra note 50, at 6; 2008 CALIFORNIA DISCIPLINE SYSTEM REPORT, supra note 100, at 5. As explained in the next Part, that probably reflects a failure to comply with reporting requirements rather than a true assessment of the volume of reporting the rule requires. See infra Part IV.C.

170 Dan Weikel \& Catherine Gewertz, Bar Not Told About Reversal of Convictions, L.A. TIMES, Oct. 3, 1993, at B1, B6 (emphasis added) (quoting then-California State Bar President Harvey Saferstein).

171 CCFAJ REPORT, supra note 14 , at $70-81$ (finding limited compliance with $\S 6086.7$ (a)(2) of the California Business \& Professions Code); accord RIDOLFI \& POSSLEY, supra note 138 , at 48 . Compliance problems in this area have even made the popular press. See, e.g., Weikel \& Gewertz, supra note 170 , at B1.

172 CCFAJ REPORT, supra note 14 , at 71.

${ }^{173}$ Id. (relying on comments from the chief trial counsel for the state bar).

174 Id.

175 Id. at 73 .

${ }^{176}$ Id.

${ }^{177}$ See Greenbaum, Judicial Reporting, supra note 4, at 564. Increased judicial training about both the reporting requirement and the state disciplinary process was among the 
Ambiguity in the rules as to who must report is a problem. Confusion here happens at several levels. First, who is the court official that should report? The statutes state that the "court" should report"179 in some instances, and in other instances direct that the "clerk" of the court should do so. ${ }^{180}$ Who is to speak for the "court"? Is it the judge presiding over the case, or the clerk of courts? On the appellate level, is it the chief judge or the judge writing the majority opinion? If an appellate court reverses a trial court decision based on lawyer misconduct, is someone from the appellate court to report, or should the original trial judge do so ${ }^{181}$ A clear declaration of who should act is important. ${ }^{182}$

Confusion also can arise from the fact that much of the conduct the court must report also must be reported by the lawyer involved. While the system builds in this redundancy as a fail-safe, some erroneously assume that if someone else may be reporting, they do not have to. ${ }^{183}$ A clear statement clarifying that this is not the case would be desirable.

Similarly, a clear statement needs to be given about the interplay between the judge's ethical rules pertaining to reporting lawyer misconduct and the statutory mandate to report in certain instances. In California, for example, the judicial ethics rules require judges to take "appropriate corrective action" when they have knowledge that a lawyer has violated the state's Rules of Professional Conduct. ${ }^{184}$ Some judges felt this provision trumped the statute and gave them

recommendations of the California Commission for the Fair Administration of Justice. CCFAJ REPORT, supra note 14, at 73. That recommendation has been implemented. RIDOLFI \& POSSLEY, supra note 138 , at 50.

178 CCFAJ REPORT, supra note 14, at 71 (noting that judges increased reporting upon receiving a letter reminding them of their reporting duties under California law); see also MCKAY REPORT, supra note 18, at 125 (noting that judges increased reporting after attending an educational program called "The Judicial Response to Lawyer Misconduct").

179 See CAL. BuS. \& Prof. CODE $\S 6086.7$ (a) (West Supp. 2012); id. § 6086.8(a) (West 2003).

${ }^{180} I d . \S 6101$ (c) (West 2003).

${ }^{181}$ CCFAJ REPORT, supra note 14 , at 71 (noting some of these ambiguities and recommending clarification).

182 For an example of one attempt to do so, see $i d$. at 17 (recommending adoption of a rule of court to clarify who is to make the required report).

183 Compare In re Varakin, 3 Cal. State Bar Ct. Rptr. 179, 188 (Review Dep't 1994) (noting the fact that though court has duty to report, and may have done so, that does not absolve lawyer from the duty to report as well), with In re Blum, 3 Cal. State Bar Ct. Rptr. 170, 176 (Review Dep't 1994) (concluding that a lawyer's awareness "that the superior court was notifying the state bar of the sanctions" substantially mitigated the failure to self-report). Accord In re Riordan, 5 Cal. State Bar Ct. Rptr. 41, 47-48 (Review Dep't 2007) (recognizing lawyer's independent duty to report imposition of sanctions even where lawyer has actual knowledge that the clerk of courts has reported, but citing Blum as to mitigation). While these cases illustrate confusion by lawyers about their self-reporting duties when the court has a reporting duty as well, it certainly is possible that judges also are confused by these multiparty obligations.

${ }^{184}$ CAL. CODE JUD. ETHICS Canon 3(D)(2) (2008), available at http://www.courts.ca. gov/documents/ca_code_judicial_ethics.pdf. 
discretion as to what corrective action was appropriate even in the face of a statutory reporting requirement. ${ }^{185}$ In short, if the judge did not feel reporting was appropriate in the circumstances, no duty would attach. One reason for reading the provisions this way seemed to be a fear that disciplinary authorities would treat some reported instances more harshly than was deserved. ${ }^{186}$ Here, the Commission's recommendation was to clarify this by making the duty to report certain misconduct absolutely clear in the state's Code of Judicial Conduct itself. 187

Even if it is clear who should act and that reporting is mandatory, it may not be clear if particular conduct triggers the reporting requirement. The more the triggering acts require judgment to see if they are met, the more likely it is that some reporting will be lost. Take, for example, the contempt category. Reporting is required of the court only where the underlying conduct involves grounds warranting professional discipline. ${ }^{188}$ Having to make the latter judgment may be difficult for a busy court. Simply requiring the reporting of all contempt orders entered against lawyers would not.

Other activities that trigger reporting also may be ambiguous. For example, courts in California are to report the reversal or modification of a judgment resulting from a lawyer's "misconduct, incompetent representation, or willful misrepresentation."189 In testifying before the California Commission for the Fair Administration of Justice, Steven Van Sicklen, Supervising Judge of the Criminal Courts in Los Angeles County, presented a litany of potential bad trial choices counsel might make and queried as to which of them constitute misconduct within the meaning of the statute. ${ }^{190}$ Presumably, the requirement to report only when the conduct leads to reversal or modification of a judgment helps identify conduct so significant, in context, that most would agree it meets the otherwise ambiguous standard. ${ }^{191}$

185 CCFAJ REPORT, supra note 14 , at 73.

186 Id.

${ }^{187}$ Id. at 17,73 .

${ }^{188}$ CAL. BUS. \& PROF. CODE $\S 6086.7$ (a)(1) (West Supp. 2012).

${ }^{189} \mathrm{Id}$ § 6086.7(a)(2).

${ }^{190}$ Steven R. Van Sicklen, L.A. Cnty. Superior Court Judge, Testimony Before the Cal. Comm'n on Fair Admin. of Justice (July 11, 2007) [hereinafter Van Sicklen Testimony], available at http://www.ccfaj.org/documents/reports/prosecutorial/expert/Judge $\% 20 \mathrm{Van}$ $\% 20$ Sicklen.pdf (pointing out this concern in attacking a proposal that would require such reporting if a finding were made meeting the standard, even if the judgment were ultimately upheld).

${ }^{191}$ But cf. People v. Crowl, No. A 127221, 2011 WL 1134469, at*10 n.17 (Cal. Ct. App. Mar. 29, 2011) (finding a duty to report prosecutorial misconduct under $\S 6086.7(\mathrm{a})(2)$ despite the fact that it was affirming the trial court's judgment, which was predicated on the same finding of prosecutorial misconduct; noting also that although the statutory terms require notification only upon "modification or reversal" of a judgment, "we do not interpret the statute as relieving us of our reporting obligation merely because the trial court found the misconduct before we did"). 
Care also must be taken to address issues of finality. Just what is the action that triggers a reporting requirement? The answer may vary by the nature of the matter to be reported. If the reporting involves imposition of a sanction, reporting might be required at the time the sanction is entered. If the reporting involves a criminal conviction, a judgment for civil damages predicated on lawyer malfeasance, or the reversal or modification of a judgment based on the same, awaiting entrance of the judgment would seem to make sense. ${ }^{192}$ Whatever the choices made, they should be clearly stated.

A related concern is how to treat subsequent activity that may overturn the reportable incident. Should that possibility delay the duty to report? This turns on how serious the misconduct is (i.e., the more serious the misconduct, the more likely disciplinary authorities will want to act upon it and to do so quickly), how long it may take to resolve the challenge, and how likely it is that the reportable action will be vacated. An additional factor is the possible impact a delayed reporting requirement would have on the primary activity of the affected lawyer. If, for example, the reporting requirement were delayed until all appeals were exhausted, a lawyer might be tempted to pursue unnecessary appeals to delay the time for reporting. ${ }^{193}$ That would not only clutter court dockets, but would impose unnecessary costs on the court and the parties. At times, it might also present a conflict between the lawyer's interest in dragging out the process and the client's interest in obtaining a final resolution of the matter. Given this mix of factors, it seems preferable to require reporting without taking possible reversal of the underlying court determination triggering reporting into account. ${ }^{194}$

As to the general reluctance of judges to report, I have argued extensively elsewhere that the factors that lead judges to underreport are vastly overstated

The definition of the term "misconduct" may also be a limiting factor. One California intermediate appellate court, in reversing a conviction on a prosecutor's Brady violation, gave the term a limiting gloss. In assessing whether this reversal created a duty to report under $\S 6086.7$, the court held that inadvertent violations do not rise to the level of "misconduct," limiting that term to conduct that is "egregious." People v. Ball, No. F055655, 2009 WL 1942427, at *7 (Cal. Ct. App. July 8, 2009).

192 In the criminal setting, one might move up the time for reporting to the time of conviction, but before sentencing, in order to get the information more quickly to disciplinary authorities on the theory that the need for public protection, and hence swift action, is usually greater in such circumstances. Regardless of the time chosen by which the court must act, nothing restricts the authority of the court to report the conduct earlier if it chooses.

193 This incentive is a real one, at least where the lawyer's conduct is such that it will likely trigger investigation and possible license suspension or revocation. Any additional time the lawyer can create before his right to practice is interrupted provides the lawyer the opportunity to handle additional matters and earn additional fees.

${ }^{194}$ See generally infra text accompanying note 245 (noting that some state self-reporting requirements for conviction of a crime impose the duty without regard to appeals or other challenges to the ruling). 
and that judges confronted with a clear duty to report will do so. ${ }^{195}$ Particularly if the concern is that discipline is too dire a consequence for the underlying conduct, judges should be reminded of the role reporting plays. As nicely stated by the California Commission on the Fair Administration of Justice, "NOT every report will lead to an investigation, and NOT every investigation will lead to discipline, but the State Bar is the most appropriate forum to exercise discretion, and the exercise of that discretion must be informed by a cumulative track record."196

\section{Indirect Consequences}

Requiring the reporting of actions taken in the litigation process may influence the behavior of those participating in the process. It may affect the behavior of the lawyer whose conduct is ultimately under scrutiny, the judge whose decision may trigger reporting, and opposing parties who may seek leverage through the reporting requirement. Implementing a reporting requirement on courts also will disproportionately impact members of the litigation bar.

Lawyers whose behavior may become the subject of reporting may alter their behavior because of the possibility their actions might trigger reporting. If, for example, the threat of reporting is tacked on to the threat of court sanction for certain conduct, the lawyer may be less likely to push the envelope on particular matters. Would a lawyer think twice about filing a pleading that might lead to Rule 11 sanctions, for example, if the imposition of that sanction would lead not only to the imposition of a penalty by the court, but also referral to disciplinary authorities? Will it induce lawyers to overlitigate cases to avoid the chance the court might find the representation incompetent? ${ }^{197}$ If the incremental impact makes a difference at all, will it lead to greater deterrence of improper conduct, or will it have a chilling effect on conduct at the margins? ${ }^{198}$

${ }^{195}$ See Greenbaum, Judicial Reporting, supra note 4, at 545-51, 559-68. One additional way to promote compliance, although not one I advocate, might be to sanction judges who fail to do so. See generally Weikel \& Gewertz, supra note 170, at B6 (noting that, in the period between 1990 and 1993, the California Commission on Judicial Performance sanctioned at least one judge for failing to report lawyer misconduct when required to do so). While lauding the California judicial reporting requirement as "admirable" and "on the cutting edge," Professor Steven Lubet cautioned against sanctioning judges for failure to report, at least to the extent it involved a "first-time offender[] whose failure to report was not willful." Id.

196 CCFAJ REPORT, supra note 14 , at 73.

197 Van Sicklen Testimony, supra note 190 (pointing out this concern in attacking a proposal that would require such reporting if a finding were made meeting the standard, even if the judgment was ultimately upheld). Again, the statutory limitation that reporting is required only when the conduct results in modification or reversal of a judgment limits the sting of this argument.

${ }^{198}$ Calibrating sanctions to achieve a desired level of regulation without chilling desirable conduct is a constant concern. See, e.g., 5A CHARLES ALAN WRIGHT \& ARTHUR R. 
And what impact does this have on judicial conduct? Under the California scheme, the decisions courts reach have an impact on whether reporting takes place. Suppose a court decides to impose monetary sanctions on a lawyer for misconduct other than those imposed in discovery. Will courts set penalties at $\$ 999.99$ or less to obviate the need for required reporting that is triggered by sanctions of $\$ 1000$ or more? ${ }^{199}$ Will judges avoid finding lawyers in contempt because invoking that power will also get the lawyer reported to the bar? In a very close case, would a judge decide not to modify or reverse a judgment based on lawyer misconduct or incompetence in order to protect the lawyer from having to be reported? ${ }^{200}$ If these consequences induce caution on a judge's part in using her sanction powers or overturning earlier decisions, is that a welcome restraint or an unwelcome inhibition?201

The triggering system also has the potential to provide leverage to prosecutors in criminal cases against lawyers, and plaintiffs in civil suits predicated upon lawyer misconduct. If in the criminal context only convictions of a certain level need to be reported, there might be plea deals offered and accepted at the point just below which reporting is required. ${ }^{202}$ If, as in the

Miller, Federal Practice and Procedure $§ 1332$, at 489-90 (3d ed. 2004) (describing criticism that the 1983 version of Federal Rule of Civil Procedure 11 chilled vigorous advocacy); $c f$. Allyn Jaffrey, Counsel, I Hold You in Contempt, 18 W. ST. U. L. REV. 87, 114-15 (1990) (noting that a mandatory reporting of contempt convictions to disciplinary counsel "may discourage aggressive advocacy").

${ }^{199}$ See Robert S. Miller, Attorneys' Fees for Contractual Non-Signatories Under California Civil Code Section 1717: A Remedy in Search of a Rationale, 32 SAN DIEGo L. REV. 535, $586 \mathrm{n} .269$ (1995) (postulating that the California reporting provision for sanctions may deter their use "especially where counsel are personally known to the presiding judge").

${ }^{200}$ See Cooney v. Park Cnty., 792 P.2d 1287, 1302 n.4 (Wyo. 1990) (Urbigkit, J., dissenting) (noting that a rule requiring judges to report to disciplinary authorities every instance in which prosecutorial misconduct led to reversal or modification of a judgment, or was commented on by the court, "would create its own danger in that the appellate court might be reluctant to reverse if the necessities of disciplinary review would automatically follow"), vacated, 501 U.S. 1201 (1991). See generally Adam M. Gershowitz, Prosecutorial Shaming: Naming Attorneys to Reduce Prosecutorial Misconduct, 42 U.C. DAVIS L. REV. $1059,1084-88$ (2009) (identifying a number of factors that may induce judges to protect prosecutors as a group, thereby keeping prosecutors' names out of opinions finding prosecutorial misconduct).

201 Van Sicklen Testimony, supra note 190 (warning of a possible "chilling effect on the Court" from an expanded reporting requirement being proposed). It is unclear from his testimony whether the chilling effect would arise from judges' fear that if they ruled in a way that would lead to reporting, lawyers might attempt to retaliate against them, or from a desire to protect the lawyers appearing before a judge. Compare id. (written testimony that seems to focus on the former), with Chris Boscia, Minutes of Public Hearing, CaL. COMMISSION ON FAIR ADMIN. OF JUST. (July 11, 2007), http://www.ccfaj.org/documents/ reports/prosecutorial/expert/Public\%20Hearing\%20Meeting\%20Minutes.pdf (summary of oral testimony that seems to focus on the latter).

202 Requiring the reporting of some but not all criminal convictions is common. See supra note 142. It is also common in the self-reporting area. For a discussion of the potential bargaining issues this raises, see infra text accompanying note 304 . 
California regime, all criminal convictions need to be reported, that leverage largely drops out of the system.

With respect to civil claims, the statute requires reporting of judgments for damages in any "civil action for fraud, misrepresentation, breach of fiduciary duty, or gross negligence committed in a professional capacity." 203 This may have the impact of encouraging the parties to settle so that there will be no judgment to report. However, one must remember that, in California, malpractice claim activity also must be reported to the disciplinary authorities. Merely settling will not keep the underlying claim out of the disciplinary file. ${ }^{204}$

Some reporting requirements might have secondary effects as well. Take, for example, the California provision that requires reporting the modification or reversal of a judgment based on incompetent attorney representation. Will criminal defense counsel be less likely to raise ineffective assistance of counsel on appeal if the result of a successful appeal is not only the protection of a client, but also the reporting of the original defense counsel? Would the original counsel be less forthcoming in testifying about his original conduct because of the fact that, if ineffective assistance of counsel were found, this would be reported to disciplinary authorities?205

Finally, the reporting scheme may appear unfair to the litigation bar. Admittedly, some of the reportable activity concerning civil and criminal judgments cuts across all segments of the bar. Any lawyer may be convicted of a crime or successfully sued for a breach of fiduciary duty. But reporting based on court-imposed sanctions or the modification or reversal of a judgment in a judicial proceeding based on the misconduct, incompetent representation, or

${ }^{203}$ CAL. Bus. \& Prof. CODE $\S 6086.8$ (a) (West 2003).

${ }^{204}$ Section 6086.8 of the California Business and Professions Code provides:

(b) Every claim or action for damages against a member of the State Bar of California for fraud, misrepresentation, breach of fiduciary duty, or negligence committed in a professional capacity shall be reported to the State Bar of California within 30 days of receipt by the admitted insurer or licensed surplus brokers providing professional liability insurance to that member of the State Bar.

(c) An attorney who does not possess professional liability insurance shall send a complete written report to the State Bar as to any settlement, judgment, or arbitration award described in subdivision (b), in the manner specified in that subdivision.

Id. $\S 6086.8$.

${ }^{205}$ John Wesley Hall, First Vice President, Nat'l Ass'n of Criminal Def. Lawyers, Testimony Before the Cal. Comm'n on Fair Admin. of Justice (July 11, 2007) [hereinafter Hall Testimony], available at http://www.ccfaj.org/documents/reports/prosecutorial/expert/ NACDL\%20Response\%20To\%20Questions.pdf (raising this concern); see also People v. Lane, No. C059605, 2010 WL 2892715, at *18 (Cal. Ct. App. July 26, 2010) (noting this concern). For a general discussion of the ethical issues facing an attomey alleged to have provided ineffective assistance of counsel, including the conflict between helping the client and harming one's own reputation, see David M. Siegel, My Reputation or Your Liberty (or Your Life): The Ethical Obligations of Criminal Defense Counsel in Postconviction Proceedings, 23 J. LEGAL PROF. 85 (1999). 
willful misrepresentation of an attorney will have a disproportionate impact on the litigation bar. As I have previously noted:

While ferreting out misconduct by any lawyer is better than not, a disproportionate focus on this one segment of the bar might be misread by the public as a sign that litigators are less ethical than other lawyers. While a possibility, one wonders just how likely it is that the public will form that opinion from a reporting regime that typically fails to attract the public eye. ${ }^{206}$

On the other hand, at some point, anti-trial lawyer groups might attempt just such a maneuver.

\section{E. Modifications to the Court Reporting Requirements}

In the previous subsections I have used the California system as an example of a multifaceted, automatic court-reporting regime and explored its benefits, costs, and indirect consequences. That said, there is nothing magic about the choices California has made. Others might choose a different set of triggers for reporting. In fact, that issue was addressed recently by the California Commission on the Fair Administration of Justice. As part of its charge, the Commission considered possible changes to the California requirement that courts report "modification or reversal of a judgment in a judicial proceeding... based in whole or in part on the misconduct, incompetent representation, or willful misrepresentation of an attorney." 207 As such, it provides a vehicle to explore some additional tensions in this area.

If we are going to utilize automatic reporting by courts to inform the disciplinary process, it is not at all clear. where the lines are appropriately drawn. Two principal issues arise. The first is what conduct should be reported. The second is how this conduct should be formally acknowledged by the court before the reporting duty should attach.

One question that arose in the Commission's work was whether the present statutory language sufficiently identifies the conduct that should be reported. Several witnesses commented that the language is too open-ended-that there is too much ambiguity in terms like "misconduct" or "incompetent representation." 208 In its final report, the Commission recommended that a list of such misconduct be included in the state's Code of Judicial Conduct. While not an exclusive list of reportable conduct, the Commission attempted to identify the issues of most significant concern in the handling of criminal cases. ${ }^{209}$ Under its proposal, reporting would be required for ${ }^{210}$ :

${ }^{206}$ Greenbaum, Judicial Reporting, supra note 4, at 550.

${ }^{207}$ CAL. Bus. \& PROF. CODE $§$ 6086.7(a)(2) (West Supp. 2012).

${ }^{208}$ See, e.g., Hall Testimony, supra note 205, at 17; Van Sicklen Testimony, supra note 190.

${ }^{209}$ Articles expressing concerns about misconduct by prosecutors and defense attorneys in criminal matters are legion. See Duncan, supra note 138, at 5-7 (describing the degree of 
- a willful misrepresentation of law or fact to a Court;

- appearing in a judicial proceeding while intoxicated;211

- engaging in willful unlawful discrimination in a judicial proceeding;

- willfully and in bad faith withholding or suppressing exculpatory evidence (including impeachment evidence) that he or she is constitutionally obligated to disclose;

- willful presentation of perjured testimony;

- willful unlawful disclosure of victim or witness information; and

- failure to properly identify oneself in interviewing victims or witnesses.

While civil matters were beyond the jurisdiction of the Commission, it did recommend, in passing, that a similar list be developed by an appropriate body for civil cases. ${ }^{212}$

One ambiguity the proposal introduces is that of intent. Under the extant statutory text, intent need be determined only for misrepresentations to the court, which must be "willful." The Commission's proposal adds willfulness to

criminal defense counsel error and suggesting more of it be policed by the bar through automatic reporting of ineffective assistance of counsel or criminal malpractice claims); THE JUSTICE PROJECT, supra note 138, at 29-30 (providing a bibliography on the topic of prosecutorial misconduct).

210 CCFAJ REPORT, supra note 14 , at $17-18,78-79$. Since the California statutes that govern reporting would not be changed under this proposal, it is unclear how these Code of Judicial Conduct changes are intended to fit with the statutory provision. I presume they both help illustrate what the statute would require, and expand the list of conduct to be reported as well.

${ }^{211}$ In proposing this standard, the Commission rejected the notion that a mere discussion between judge and counsel would be sufficient to control what may be a repeated problem before a number of judges. Id. at 76 . One might also add a reporting requirement for a lawyer appearing disoriented or displaying other mental conditions that raise questions as to the lawyer's fitness to practice. While the initial report would be to disciplinary authorities, that report might often lead to referral to a lawyers' assistance program. Id.

$212 \mathrm{Id}$. at 75 . Many of the proposed triggers would be applicable in civil actions as well. In addition, disqualification (as a key to conflict-of-interest concerns) and dismissals for failure to prosecute, pursue an appeal once filed, or appear at a hearing (as a key to competence and diligence) might be added. In the latter regard, see D. MD. R. 602 (providing for the fining of attorneys who fail to appear, or are late for a proceeding, or fail to file a timely status report, and requiring referral to disciplinary counsel if more than two such fines have been imposed on an attomey in a five-year period). Obvious mental health issues might be added as well. See supra note 211 . For a general discussion of possible starting places in creating an expanded list of triggers, see JUDICIAL RESPONSE TO LAWYER MISCONDUCT, supra note 152 (identifying misconduct judges should report in the following categories: prosecutorial misconduct, incompetence and negligence, deception of the court, frivolous lawsuits and discovery abuse, in-court misconduct, contemptuous behavior, and conflicts of interest). See also Brown, supra note 5, at 1561-62 n.17 (suggesting the idea that automatic reporting could be required of Rule 11 sanctions and other forms of litigation misconduct, such as discovery abuse or the discriminatory use of peremptory challenges). 
five of the seven actions that would trigger reporting. ${ }^{213}$ If willfulness is not readily apparent, courts may avoid that inquiry unless otherwise germane to the outcome of the case before them. Further, very bad lawyering not involving willful misconduct will be shielded from mandatory disclosure in some instances.

The Commission also considered what sort of impact the lawyer's conduct must have to warrant reporting. A number of witnesses challenged the present standard, which requires reporting only if the conduct results in the modification or reversal of a judgment. This, they argued, simply screens out too much conduct that should get into a lawyer's disciplinary file. Excluded under this standard are case dismissals necessitated by lawyer misconduct before a judgment is entered. It also excludes cases of substantial misconduct or incompetence that nevertheless do not affect the case sufficiently to warrant a change in the original judgment. ${ }^{214}$ These critics argued that reporting should be required whenever a court makes a finding that the lawyer engaged in misconduct, incompetent representation, or willful misrepresentation. ${ }^{215}$

213 The concept of willfulness has different meanings in different contexts. See BLACK'S LAW DiCTIONARY 1737 (9th ed. 2009). As used here, the Commission seems to be focusing on "deliberate" acts as opposed to those that are careless or inadvertent. See CCFAJ REPORT, supra note 14 , at $75-77$. This seems analogous to a recent ABA resolution urging courts, in criminal cases reviewing prosecutorial conduct, to differentiate between "error" (unintentional, inadvertent, or negligent conduct) and "misconduct" (conduct known by the prosecutor to be improper and prejudicial). House of Delegates Resolution 100B, A.B.A. (Aug. 9-10, 2010), http://www.americanbar.org/content/dam/aba/migrated/leadership/2010/ annual/pdfs/100b.authcheckdam.pdf.

${ }^{214}$ CCFAJ REPORT, supra note 14 , at 72 (noting that reversal of a judgment "depends upon factors such as the strength of other evidence which may have nothing to do with the egregiousness of the misconduct or incompetence"). See generally CTR. FOR PUB. INTEGRITY, HARMfUl ERror: INVESTIGATING AMERICA's LOCAL ProseCUTORS 108 (2003) (studying 11,452 cases in which defendants alleged prosecutorial misconduct and finding misconduct in 10,721 of those cases-8709 of which were treated as harmless error). In a study conducted for the California Commission on the Fair Administration of Justice, Professor Kathleen Ridolfi concluded, after studying 2130 California cases in which claims of prosecutorial misconduct were raised, that modification or reversal is not a proxy for the egregiousness of misconduct as she found "no meaningful difference between the conduct of the prosecutors in the cases 'modified or reversed' from the actions of prosecutors in harmless error cases." KathleEN Ridolfi, SANTA Clara UNIV. Sch. OF LAW, Prosecutorial MisconduCT: A SYSTEMATIC REVIEW 14 (2007).

215 CCFAJ REPORT, supra note 14 , at $72-73$. This suggestion subsequently has been endorsed by The Justice Project. ThE JUSTICE ProjeCT, supra note 138, at 3-4, 10-12; see also Kenneth Williams, The Death Penalty: Can It Be Fixed?, 51 CATH. U. L. REV. 1177, 1200 (2002) (advocating automatic court reporting of prosecutorial misconduct findings to disciplinary authorities). Some have advocated that the mere raising of a claim with respect to a reportable incident should be reported. Duncan, supra note 138, at $45-46$ (promoting automatic reporting to the bar of any ineffective assistance of counsel or criminal malpractice claim). Others have suggested the line should include not only instances of prosecutorial misconduct necessitating modification or reversal of the original judgment, but 
Opponents to that change worried that this would provoke litigants to request what were otherwise unnecessary findings, which would involve the court in extraneous matters. It was also suggested that courts might simply refuse to make findings on certain matters to avoid having to report counsel to the bar. ${ }^{216}$ At a minimum, it might change the dynamic of the litigation process in negative ways. 217

In the end, the Commission premised reporting on the court having "personal knowledge" or having made a "finding" that a reportable event occurred. ${ }^{218}$ While eliminating the requirement that the lawyer's conduct result in modification or reversal of a judgment, ${ }^{219}$ the Commission substituted a different filter to assure that the conduct is of sufficient severity to warrant reporting by limiting the reporting duty to "egregious misconduct." 220 The seven categories of conduct expressly listed reflect the most common misconduct to meet the standard, and provide a template upon which to compare unlisted conduct.

\section{F. Recommendation}

As I have written elsewhere, I strongly believe that judges can and should play a more active part in reporting lawyer misconduct. ${ }^{221}$ Judges are well situated to witness and evaluate certain forms of misconduct, ${ }^{222}$ and their role in the system as the gatekeepers of the profession should engender a willingness to do so. ${ }^{223}$

One way to promote judicial reporting, and one I endorse, is through a combination of mandatory reporting for discretely defined violations and a more general reporting duty for other misconduct. Creating a clear-cut category of conduct that must be reported puts courts on notice of conduct of which

also "when a court sees fit to comment adversely on a prosecutor's conduct." JUDICIAL RESPONSE TO LAWYER MISCONDUCT, supra note 152, at I.14.

216 CCFAJ REPORT, supra note 14, at 73.

${ }^{217}$ Cf. In re Attorney C, 47 P.3d 1167, 1174 (Colo. 2002) (narrowing the instances in which discovery violations by prosecutors in criminal cases would be subject to discipline because of the "danger" that the rules might be "subverted[,]" with the rules "invoked ... as procedural weapons" that "could be used to obstruct the progress of a case[,]" and because "[the court does] not wish the possibility of a grievance proceeding to permeate every discovery dispute in criminal cases" (citation omitted)).

218 CCFAJ REPORT, supra note 14 , at 80 (recommendation 3 ).

219 See RIDOLFI \& POSSLEY, supra note 138, at 79-80 (endorsing this change).

220 CCFAJ REPORT, supra note 14 , at 80 . That limitation already had been recognized under the present statutory language by a least one California intermediate appellate court. People v. Ball, No. F055655, 2009 WL 1942427, at *7 (Cal. Ct. App. July 8, 2009) (reversing a conviction on a prosecutor's Brady violation, but holding that inadvertent violations do not rise to the level of "misconduct" under $\S 6086.7$, and limiting that term to conduct that was "egregious").

221 See Greenbaum, Judicial Reporting, supra note 4, at 537.

222 Id. at 543-45.

${ }^{223} \mathrm{Id}$. at 560 . 
disciplinary authorities want to be apprised. This does not mean a report will trigger disciplinary action, although in instances of egregious misconduct it might. But it does mean that repeated misconduct, often before different judges, will be captured and appropriate responses will follow. Further, the mandatory nature of the duty does much to take the sting out of the reporting act itself. Reporting ceases to be a voluntary, hostile act, and becomes instead an unavoidable necessity. With mandatory reporting as a base, the addition of a more open-ended reporting obligation gives courts greater discretion in other areas to determine whether reporting is warranted.

Admittedly, difficult judgments need to be made in determining what conduct warrants mandatory reporting. ${ }^{224}$ Ministerial questions of who within the judicial system should make the actual report and what that report should entail also arise. ${ }^{225}$ Some fervently believe that mandatory reporting will affect the primary conduct of judges and the lawyers that practice before them. ${ }^{226}$ In the end, however, any regime that gives judges power to sanction lawyers, like the sanctioning authority available to trial court judges to regulate litigation misconduct, has similar implications (on occasion, sanctions will be requested for strategic reasons, judges will want to protect some lawyers who appear before them, etc.). And yet these systems, if well-tailored, seem to function without undue indirect consequences. ${ }^{227}$ Here a judge's actions are even less severe; the act of reporting imposes no sanction itself, but only provides information to disciplinary authorities for some possible future action. ${ }^{228}$

224 See supra Part IV.E.

225 See supra text accompanying notes $179-82$.

${ }^{226}$ See supra Part IV.D.

${ }^{227}$ While courts admittedly are reluctant to sanction lawyers who appear before them, they actively use their powers to do so. See, e.g., Greenbaum, Judicial Reporting, supra note 4, at 561 n.98. See generally Judith A. McMorrow et al., Judicial Attitudes Toward Confronting Attorney Misconduct: A View from the Reported Decisions, 32 HOFSTRA L. REV. 1425 (2004). But $c f$. CORINA GERETY, UNIV. OF DENVER INST. FOR THE ADVANCEMENT OF THE AM. LEGAL SYS., EXCESS \& ACCESS: CONSENSUS ON THE AMERICAN CIVIL JUSTICE LANDSCAPE 13 (2011) (noting a consistent result in surveys of lawyers to the effect that "sanctions allowed by the discovery rules are seldom imposed" but not evaluating the reasons for this).

228 If the automatic court reporting of certain lawyer misconduct proves valuable, reporting might be desired from all courts, state and federal, across all U.S. jurisdictions. Jurisdictional limitations, however, would prevent one system from requiring reporting by another. Nevertheless, courts might voluntarily decide to report lawyer misconduct to other systems in which the lawyer is licensed. See, e.g., N.D. \& S.D. MIss. CIV. R. 83.1(c)(1) (requiring clerk of courts to report the revocation or suspension of a lawyer's admission to practice before the court to disciplinary authorities of the states in which the lawyer is licensed). Even if that does not occur, this reporting gap can be filled somewhat by requiring lawyers licensed in a state to self-report certain judicial actions occurring in other jurisdictions, as well as those in the state of licensure. For a discussion of self-reporting, see infra Part V. 


\section{LAWYER SELF-REPORTING OF PARTICULAR EVENTS}

Under the former Model Code of Professional Responsibility, lawyers were required to report their own misconduct to disciplinary authorities. ${ }^{229}$ In successor codes, that responsibility was dropped in recognition of the fact that it proved unenforceable. ${ }^{230}$ While this broad self-reporting rule largely has been eliminated, a limited duty of self-reporting is retained by the majority of states. ${ }^{231}$ While these provisions vary in their details, they typically require the lawyer to report criminal convictions or out-of-state disciplinary actions ${ }^{232}$ to appropriate authorities in states where the lawyer is licensed to practice. ${ }^{233}$ More unusual is a requirement for the lawyer to report the filing of criminal charges as well as their subsequent resolution. ${ }^{234}$ California is unique in requiring all of these plus an explicit requirement to report most court-imposed

${ }^{229}$ Model Code of Prof'l Responsibility DR 1-103(A) (1980). The duty did not apply, however, when reporting would implicate the lawyer's Fifth Amendment privilege against self-incrimination. See ABA Comm. on Ethics and Prof'1 Responsibility, Informal Op. 1279 (1973).

${ }^{230}$ Ctr. For Prof'L Responsibility, Am. Bar Ass'N, A Legislative History: The DEVELOPMENT OF THE ABA MODEL RulES OF PROFESSIONAL CONDUCT 1982-2005, at 798 (2006). Nevertheless, the duty remains in some jurisdictions. See, e.g., OHIO R. PROF. CONDUCT 8.3(a).

${ }^{231}$ Self-reporting, of some nature, is required in all but eight states. See Timothy Conrad, Self-Reporting Fifty-State Survey (July 14, 2011) (unpublished spreadsheet) (on file with author).

232 In addition, some states require lawyers to certify their compliance with the state's trust account recordkeeping requirements. See, e.g., Fla. R. REgulating Fla. BAR 51.2(c)(5); N.H. SuP. CT. R. 50-A(1); WIS. R. Prof. CondUCT 20:1.15(i)(1)-(2); 2008 Trust Accounting Certificate, OKLA. B. ASS'N, http://www.okbar.org/obf/IOLTACompliance.pdf (last visited Mar. 9, 2012). Some states have gone further and require lawyers to report and explain any overdrafts and any shortages of funds in the account from that which should be there. See, e.g., S.D. CoDIFIED LAWs § 16-18-20.2 (2011); New Hampshire Supreme Court Annual Trust Accounting Compliance Certificate for 2007, N.H. B. Ass'N, www.nhbar.org/uploads/pdf/TrustAccountComplianceForm2007.pdf (last visited Mar. 9, 2012). The New Hampshire requirement was subsequently repealed. Id.

233 The provisions clearly apply to lawyers licensed by the jurisdictions that have adopted them. They likely apply to those who, while not licensed fully to practice, do so on a limited basis such as by in-house counsel registration or pro hac vice admission. The ABA's Model Rule for Registration of In-House Counsel expressly requires self-reporting of "any change in the lawyer's license status in another jurisdiction, including by the lawyer's resignation [and] ... [w] hether or not public, any disciplinary charge, finding, or sanction concerning the lawyer by any disciplinary authority, court, or other tribunal in any jurisdiction." MODEL RULE FOR REGISTRATION OF IN-HOUSE COUNSEL $\S \mathrm{D}(3)$ (2008). With respect to those admitted pro hac vice, reporting may be required to the court in which counsel is appearing. See, e.g., R. Gov. ADMISSION ALA. STATE BAR VII(H); ARIZ. R. SUP. CT. 38(a)(7); VA. SUP. CT. R. 1A:4(7).

${ }^{234}$ CAL. BuS. \& PROF. CODE $\S 6068(0)(4)-(5)$ (West 2003 \& Supp. 2012) (reporting at charging stage is limited to felonies, whereas reporting of convictions is broader); FLA. R. REGUlating Fla. BAR 3-7.2(c), (e); MD. R. 16-771(a); N.J. CT. R. 1:20-13(a)(1). 
sanctions and certain lawsuits in which the lawyer's professional behavior is called into question. ${ }^{235}$

Across the states, there is some variance in how the reporting duty is structured. The most significant variations turn on what event triggers the reporting requirement and how soon thereafter the lawyer must report.

With respect to criminal violations, the rules vary on the nature of the crimes committed and the disposition required before the reporting duty attaches. For example, some states limit reporting to convictions for "serious crimes." 236 A typical definition is that:

A "serious crime" is any felony or any lesser crime that reflects adversely on the lawyer's honesty, trustworthiness or fitness as a lawyer in other respects, or any crime a necessary element of which, as determined by the statutory or common law definition of the crime, involves interference with the administration of justice, false swearing, misrepresentation, fraud, deceit, bribery, extortion, misappropriation, theft, or an attempt, conspiracy or solicitation of another to commit a "serious crime." 237

Others require reporting convictions of any crime, ${ }^{238}$ and still others fall somewhere in between. For example, Virginia requires reporting of felony

${ }^{235}$ CAL. BUS. \& PROF. CODE $\S 6068(0)$ (West 2003). For a discussion of the other aspects of the California system, see infra Part V.E.

${ }^{236}$ CONN. R. SUPER. CT. § 2-41(a); IDAHO BAR COMM’N R. 512(a); MD. R. 16-771(a); NEB. SUP. CT. R. \& 3-326(B).

${ }^{237}$ MODEL RULES FOR LAWYER DISCIPLINARY ENFORCEMENT R. 19(C) (2002); see also CONN. R. SUPER. CT. $\$ 2-41(\mathrm{c})$ ("The term 'serious crime' ... [includes] any felony or any larceny as defined in the jurisdiction in which the attorney was convicted or any crime for which the attorney was sentenced to a term of incarceration or for which a suspended period of incarceration or a period of probation was imposed.").

238 IND. ADMISSION \& DisCIPLINE R. $23 \S 11$.1(a)(2); ME. BAR R. 7.3(d)(6); MICH. CT. R. 9.120(A); WIS. SUP. CT. R. 21.15(5). That still begs the question of what is a crime. An article on the Wisconsin provision highlights the difficulties:

The definition of what constitutes "any crime" is not clear from the language of the Supreme Court Rule. The OLR interprets this rule as requiring a lawyer to report any finding of guilty or conviction of a crime as defined in Wis. Stat. section 939.12. That statute provides that "a crime is conduct which is prohibited by state law and punishable by fine or imprisonment or both. Conduct punishable only by a forfeiture is not a crime." This likely would include any misdemeanor or felony conviction or any crime for which the attorney is found guilty except for traffic violations and first-offense operating-while-intoxicated charges. It also is important to recognize that the crime could take place anywhere, not just in Wisconsin, and the obligation to notify the OLR and the clerk of the supreme court would still apply. Also, if a particular offense is considered a crime in another jurisdiction, the requirement to notify the OLR and the supreme court clerk would apply even if the offense would not constitute a crime in Wisconsin. It has not been determined whether a finding of guilty or conviction of a municipal ordinance violation that has a counterpart criminal statute would trigger the obligation of a lawyer to provide a report to the OLR and the supreme court clerk. 
convictions and any "crime involving theft, fraud, extortion, bribery or perjury or an attempt, solicitation or conspiracy to commit" such offenses. ${ }^{239}$ Nevada requires reporting of any crime "other than a misdemeanor traffic violation not involving the use of alcohol or a controlled substance." 240 California requires reporting of a conviction of:

[A]ny felony, or a misdemeanor committed in the course of the practice of law, or in a manner in which a client of the attorney was the victim, or a necessary element of which, as determined by the statutory or common law definition of the misdemeanor, involves improper conduct of an attorney, including dishonesty or other moral turpitude, or an attempt or a conspiracy or solicitation of another to commit a felony or any misdemeanor of that type. ${ }^{241}$

States also vary in how they phrase the definition of "conviction," although it is not at all clear whether the differences in language are meant to impose different requirements. Some states simply speak of "conviction" of a crime 242 or to having been "found guilty." 243 Others provide a list of acts that trigger reporting. The most expansive is Nevada's, which provides "in addition to a final judgment of conviction, a 'conviction' shall include a plea of guilty or nolo contendere, a plea under North Carolina v. Alford, 400 U.S. 25 (1970), or a guilty verdict following either a bench or a jury trial."244 Many states specify that the reporting must take place after a conviction regardless of whether an appeal or other challenge to the conviction pending follows. ${ }^{245}$

As with criminal convictions, there is substantial variance among the states in terms of what disciplinary sanctions should be reported and what, if any, quasi-disciplinary matters should be reported as well. Jurisdictions also phrase differently the disciplinary authorities whose sanctions should be reported.

Most common is a simply stated requirement for the lawyer to report being disciplined in another jurisdiction. ${ }^{246}$ This leaves ambiguous what actions

Dean R. Dietrich, Self-Reporting Lawyer Misconduct, WIS. LAW., Sept. 2008, at 21, 21-22 (2008).

${ }^{239}$ VA. R. PROF. CONDUCT $8.3(\mathrm{e})(2)-(3)$.

240 NEV. SUP. CT. R. $111(2)$.

241 CAL. Bus. \& PROF. CODE $\S 6068(0)(5)$ (West 2003 \& Supp. 2012).

242 CONN. R. SUPER. CT. \$ 2-41(a); IDAHO BAR COMM'N R. 512(a); ME. BAR R. 7.3(d)(6); Mich. CT. R. 9.120(A); VA. R. PROF. CONDUCt 8.3(e)(3); W. VA. R. LAWYER DISCIPLINARY P. 3.18(a).

${ }^{243}$ IND. ADMISSION \& DiSCIPLINE R. 23 11.1(a); WIS. SuP. CT. R. 21.15(5) (using the language "found guilty or convicted").

244 NEV. SUP. CT. R. $111(1)$.

245 Ill. SUP. CT. R. 761(a)(2); Me. Bar R. 7.3(d)(6); Nev. SuP. CT. R. 111(1); PA. R. DISCIPLINARY ENFORCEMENT 214(a). Nevada also has a similar provision with respect to disciplinary actions. In contrast, Virginia requires reporting only when the conviction or decision has become final. The rule is silent on the effect of appeal on this finality consideration. VA. R. PROF. CONDUCT 8.3(e)(3) cmt. 6.

246 See, e.g., ARIz. R. SUP. Cr. 57(b)(1); CONN. R. SUPER. CT. § 2-25; NEB. SUP. CT. R. § 3-321(a); N.D. R. LAWYER DISCIPLINE 4.4(A); OHIO GOV. BAR R. V(11)(F)(1); S.D. 
constitute "discipline." Do these rules apply only to discipline for violating a state's professional responsibility rules, or do they go further to include other court-imposed sanctions for lawyer misconduct, such as Rule 11 sanctions, contempt, or violations of agency-imposed ethical standards $?^{247}$ Other states seek to limit reporting to more significant disciplinary actions, limiting reporting to instances where public discipline was imposed, hence excluding private discipline, ${ }^{248}$ or where a severe sanction is imposed, such as suspension, disbarment, or revocation of license or pro hac vice status. ${ }^{249}$

In addition to the focus on disciplinary sanctions, some jurisdictions also identify quasi-disciplinary matters to be reported. ${ }^{250}$ Most common are requirements to report if one has been put on inactive status for disability reasons $^{251}$ or resigned from the bar in the face of pending disciplinary action. ${ }^{252}$ Others are even broader, adding to the list the requirement to report any transfer to inactive status and any interim suspension. 253

States also vary in terms of what entities' sanctions should be reported. The most common language simply provides that one should report being disciplined "in another jurisdiction." 254 Whether that is limited to sanctions that

CODIFIED Laws §16-19-71 (2011); TENN. SUP. CT. R. 9 § 17.1; VT. SUP. CT. AdMIN. ORdER 9 , R. 20(A). Idaho requires reporting whenever "a [s]anction has been imposed" on the lawyer in another jurisdiction. IDAHO BAR COMM'N R. 513(a).

${ }^{247}$ Certainly if one wanted a limited construction, the rule could be so drafted. See, e.g., N.C. R. PROF. CONDUCT 8.3(d) (requiring reporting if one has been "disciplined in any state or federal court for violation of the Rules of Professional Conduct in effect in such state or federal court"); VA. R. PROF. CONDUCT 8.3(e)(1) (requiring reporting if "the lawyer has been disciplined by a state or federal disciplinary authority, agency or court in any state, U.S. territory, or the District of Columbia, for a violation of rules of professional conduct in that jurisdiction").

${ }^{248}$ See, e.g., W. VA. R. LAWYER DisciplinaRY P. 3.20(b). For a discussion of the stillprevalent use of private discipline, see Levin, supra note 14, at 3, 20 (noting that many jurisdictions impose private sanctions, and that in many of those states, it is the most common form of discipline).

${ }^{249}$ See, e.g., PA. R. DisCIPLINARY ENFORCEMENT 216(e); see also ARK. P. REgUlating PROF. CONDUCT 14(A) (requiring reporting of disciplinary actions resulting in suspension or disbarment).

${ }^{250}$ For example, Massachusetts requires reporting not only if discipline has been imposed in another jurisdiction, but also if the lawyer's right to practice "has otherwise been curtailed or limited." MASS. R. SUP. CT. 4:01, § 16.

${ }^{251}$ See, e.g., ARK. P. Regulating Prof. Conduct 14(A); Del. LaWyers' R. DISCIPLINARY P. 18(a); MD. R. 16-773(a); N.J. CT. R. 1:20-14(a)(1); S.C. APP. CT. R. 413(29); WASH. R. ENFORCEMENT LAWYER CONDUCT 9.2(a). It is unclear whether states that predicate reporting on the imposition of discipline would expect this to fall within that requirement.

${ }^{252}$ See, e.g., HAw. R. SUP. CT. 2.15(a)(1); MD. R. 16-773(a); PA. R. DiscIPLINARY ENFORCEMENT 216(e); W. VA. R. LAWYER DISCIPLINARY P. 3.20(b).

253 See, e.g., HAW. R. SUP. CT. 2.15(a)(4).

${ }^{254}$ See, e.g., ARIZ. R. SuP. CT. 57(b)(1); CONN. R. SuPER. CT. $\$ 2-41$; NEB. SUP. CT. R. § 3-321(a); N.D. R. LAWYER Discipline 4.4(A); OHIO GOV. BAR R. V(11)(F)(1); S.D. 
arise from the state's professional disciplinary process or extends to courtimposed or agency-imposed sanctions is unclear. ${ }^{255}$ Some states articulate more fully those entities whose sanctions must be reported. Typically they specify disciplinary actions taken by any state or federal court, ${ }^{256}$ and many extend this to sanctions imposed by administrative agencies as well. ${ }^{257}$

Finally, states also differ in terms of the time frame in which the self-report must occur. The periods typically range from "immediately" 258 to thirty days after the triggering event. ${ }^{259}$ Requiring reporting "promptly" after the event is

Codified Laws $§ 16-19-71$ (2011); TenN. SuP. Ct. R. 9 § 17.1; VT. SuP. Ct. AdMIN. ORder 9, R. 20(A).

255 In an analogous area, questions have arisen as to what constitutes a disciplinary order from another "jurisdiction" warranting reciprocal discipline. That term, as used in state reciprocal discipline rules, has been read narrowly in some states to exclude regulatory bodies, like the Securities and Exchange Commission, that discipline lawyers practicing before them but do not independently license them to practice before them at the outset. See, e.g., Fla. Bar v. Tepps, 601 So. 2d 1174, 1175 (Fla. 1992); Disciplinary Counsel v. Lapine, 942 N.E.2d 328, 330-31 (Ohio 2010); cf. Stanley v. Ligon, 285 S.W.3d 649, 654 (Ark. 2008).

256 See, e.g., Ark. P. Regulating Prof. Conduct 14(A); N.C. R. Prof. Conduct 8.3(d). Some state provisions go into even more detail. See, e.g., CONN. R. SUPER. CT. § 2-25 (requiring notification of "all disciplinary actions imposed by the courts of another state, the District of Columbia, or the commonwealth of Puerto Rico, or of any United States court"); N.J. CT. R. 1:20-14(a)(1) (requiring the reporting of any disciplinary sanction by "any federal court of the United States or the District of Columbia, a state or federal administrative agency or other tribunal, a court of any state, territory, commonwealth or possession of the United States"). Pennsylvania extends this to discipline by a military tribunal. PA. R. DISCIPLINARY ENFORCEMENT 216(e).

Because the disciplinary power typically flows from the courts, this focus on the courts would encompass sanctions flowing from a state's disciplinary process; but because states vary in that process, some rules address the matter more directly by denoting that sanctions imposed by disciplinary authorities must be reported. See, e.g., ARK. P. REGULATING PROF. CONDUCT 14(A); LA. CT. R. XIX, § 21(A); VA. R. PROF. Conduct 8.3(e)(1). California requires the reporting of disciplinary sanctions imposed by a "professional or occupational disciplinary agency or licensing board." CAL. BUS. \& PROF. CODE $§$ 6068(o)(6) (West 2003 \& Supp. 2012).

${ }^{257}$ See, e.g., N.J. CT. R. 1:20-14(a)(1) (state or federal agency); PA. R. DISCIPLINARY Enforcement 216(e) (federal agency); VA. R. Prof. Conduct 8.3(e)(1) (state or federal agency).

${ }^{258}$ See, e.g., N.H. SUP. CT. R. $37(12)($ a).

${ }^{259}$ A number of states impose a thirty-day requirement. See, e.g., ARIz. R. SUP. CT 57(b)(1); CONN. R. SUPER. CT. § 2-25; ILL. SUP. CT. R. 761(a); ME. BAR R. 7.3(d)(6); NEV. SuP. CT. R. 111(2); N.C. R. Prof. CONDUCT 8.3(d); OHIO GoV. BAR R. V(11)(F)(1); WaSh. R. ENFORCEMENT LAWYER CONDUCT 9.2(a); W. VA. R. LAWYER DISCIPLINARY P. 3.18(a), 3.19(a). Others fall in between, with ten days being the most common. See, e.g., CoLo. R. CIV. P. 251.20; Del. LAWYERS' R. DISCIPLINARY P. 16(k); D.C. BAR R. XI(10)(a); Fla. R. REgulating Fla. BAR 3-7.2(c), (e); IND. AdMISSION \& DisCIPLINE R. 23 § 11.1(a); MASS. R. SUP. CT. 4:01, § 12. 
also common. ${ }^{260}$ To the extent the provision is silent as to the time period in which to report, ${ }^{261}$ a prompt reporting requirement should probably be inferred. ${ }^{262}$

\section{A. Usefulness of the Information to Disciplinary Authorities}

Obtaining information about the criminal convictions and disciplinary sanctions entered against lawyers is important for disciplinary authorities. Criminal conviction information impacts the disciplinary system in at least two ways. The mere fact of conviction may warrant the imposition of an immediate temporary suspension of the lawyer from practice. ${ }^{263}$ The underlying conduct also may violate one or more rules of professional conduct in the state.

The idea behind interim suspensions is that conviction of a crime of sufficient magnitude throws into question whether the lawyer has the character to deal honestly with clients and to serve them loyally in their representations. ${ }^{264}$ It also is a nod to the reality that the punishment associated with these crimes may, as a practical matter, impede the lawyer's ability to handle matters competently and diligently. ${ }^{265}$ Maintaining public confidence in lawyers and the disciplinary system also is served by taking immediate action

260 See, e.g., DEL. LAWYERS' R. DISCIPLINARY P. 18(a); MD. R. 16-771(a); NEB. SUP. CT. R. § 3-321(A); N.J. CT. R. 1:20-13(a)(1), 1:20-14(a)(1); N.D. R. LAWYER DISCIPLINE 4.4(A); S.C. APP. Cr. R. 413(29)(a); S.D. CODIFIED LAWS § 16-19-71 (2011); VT. SUP. CT. ADMIN. ORDER 9, R. 20(A).

261 See, e.g., VA. R. Prof. Conduct 8.3(e).

262 This is the common gloss put on the general duty of lawyers to report the misconduct of others, which is silent as to timing. See Greenbaum, Attorney's Duty to Report, supra note 4 , at 298 . For consistency, it probably should be imported here.

263 The ABA began promoting the idea of interim suspensions for criminal convictions of serious crimes more than forty years ago. See SPECIAL COMM. ON Evaluation of DisCIPLINARY ENFORCEMENT, AM. BAR ASS'N, PROBLEMS AND RECOMMENDATIONS IN DISCIPLINARY ENFORCEMENT 122-30 (1970) [hereinafter CLARK REPORT], available at http://www.americanbar.org/content/dam/aba/migrated/cpr/reports/Clark_Report.authcheckd am.pdf. It called again for the adoption of such interim suspension rules in a major report on lawyer discipline in the early 1990s. See MCKAY REPORT, supra note 18, at 56. Interim suspensions for criminal convictions of serious crimes remain a recommended disciplinary procedure. See MODEl RULES FOR LAWYER DisCIPLINARY ENFORCEMENT R. 19(D) (2002). In 2009, interim suspensions were entered in thirty-eight jurisdictions (thirty-seven states and the District of Columbia). See Ctr. for Prof'l Responsibility, Chart II: Sanctions Imposed 2009, A.B.A. (Nov. 2010), http://www.americanbar.org/content/dam/aba/migrated/ cpr/discipline/09-ch2.authcheckdam.pdf.

${ }^{264}$ Fear has also been expressed that lawyers knowing they face imprisonment and probable loss of license will be more likely to exploit current clients for their own gain. See CLARK REPORT, supra note 263, at 125 . Even if they would not, other lawyers who know of the criminal conduct may be reluctant to deal with the convicted lawyer, which, in turn, will undercut that lawyer's ability to represent existing clients. Id.

$265 \mathrm{Id}$. 
against lawyer/criminals. ${ }^{266}$ While the interim suspension is in place, authorities then determine what, if any, disciplinary action is appropriate.

The conduct underlying criminal activity also may warrant disciplinary sanction in its own right. This is seen most clearly in Rule 8.4(b) of the Model Rules of Professional Conduct, which prohibits "commit[ing] a criminal act that reflects adversely on the lawyer's honesty, trustworthiness or fitness as a lawyer in other respects." 267 The few states that require the lawyer to self-report both the filing of charges and the case resolution, rather than just the case resolution alone, are probably motivated by this concern. ${ }^{268}$ Disciplinary actions turn on a lower standard of proof than criminal actions, so knowing of the charges might lead to a disciplinary investigation even if the lawyer is ultimately acquitted in the criminal matter. ${ }^{269}$

Information concerning disciplinary actions in other states is relevant because it typically triggers reciprocal discipline. ${ }^{270}$ Under this concept, disciplinary actions taken in one state against a lawyer are usually imposed by other states in which the lawyer is licensed as well. For example, suppose Lawyer $A$ is licensed to practice in Ohio and Michigan. If Michigan found $A$ to have violated his ethical responsibilities in a case that warranted disbarment, Ohio would, in the usual case, follow suit. 271 Only in that way could the true impact of the initial punishment be felt-the lawyer would not be able to practice. Carrying over the sanction from another jurisdiction in the usual case protects potential clients from "a lawyer who has been judicially determined to be unfit."272 It also avoids the unseemly situation of a lawyer found unfit in one jurisdiction being deemed good enough in another, which may undermine the

266 As the Clark Report found, "No single facet of disciplinary enforcement is more to blame for any lack of public confidence in the integrity of the bar than the policy that permits a convicted attorney to continue to practice while apparently enjoying immunity from discipline." Id. at 124; accord MODEL RULES FOR LAWYER DISCIPLINARY ENFORCEMENT R. 19(D) cmt.

${ }^{267}$ MODEL RULES OF PROF'L CONDUCT R. 8.4(b) (2009). It should be recognized that this rule does not speak to all criminal acts of a lawyer, but only those that reflect adversely on the lawyer's honesty, trustworthiness, or fitness to practice. Mere crimes of moral turpitude that do not implicate these factors are not covered by this rule. Id. R. 8.4(b) cmt. 2 .

268 See supra text accompanying notes $231-35$.

269 In criminal actions, guilt must be shown beyond a reasonable doubt, see In re Winship, 397 U.S. 358, 361-64 (1970), whereas in disciplinary actions a clear and convincing evidence standard typically applies, see, e.g., MODEL RULES FOR LAWYER DISCIPLINARY ENFORCEMENT R. 18(C).

270 The ABA promoted the idea of reciprocal discipline more than forty years ago. See CLARK REPORT, supra note 263, at 116-21. It called again for its adoption in a major report of lawyer discipline in the early 1990s. See MCKAY REPORT, supra note 18, at 56. Reciprocal discipline remains a recommended disciplinary procedure. See MODEL RULES FOR LAWYER DISCIPLINARY ENFORCEMENT R. 22. It has been adopted in some form in most, if not all, jurisdictions.

271 See OHIO GOV. BAR R. V(11)(F).

272 See MODEL RULES FOR LAWYER DISCIPLINARY ENFORCEMENT R. $22 \mathrm{cmt}$.; see also CLARK REPORT, supra note 263, at 117. 
public's confidence in the profession and the administration of justice. ${ }^{273}$ Most states allow exceptions under certain circumstances, such as where the underlying conduct warrants substantially different discipline in the second state than the first, ${ }^{274}$ the original proceedings were so deficient as to constitute a denial of due process, ${ }^{275}$ or the proof in the original action was so insufficient that reciprocal discipline would be inappropriate. ${ }^{276}$

Placing a duty on lawyers to self-report criminal convictions and disciplinary sanctions helps the disciplinary system indirectly as well. First, such a duty may actually work to curb lawyer misconduct in the first place. Requiring lawyers to report certain misconduct may serve as a reminder to them to avoid engaging in the behavior that would necessitate reporting. Second, in a world of multijurisdictional practice, lawyer self-reporting is particularly important. Because states cannot require entities in other states to report to them directly, lawyer misconduct occurring outside of the state of one's licensure may not come to the attention of the authorities in the attorney's home state without self-reporting. ${ }^{277}$

273 See MODEL RULES FOR LAWYER DISCIPLINARY ENFORCEMENT R. $22 \mathrm{cmt}$; see also CLARK REPORT, supra note 263, at 117.

${ }^{274}$ See, e.g., Ala. R. Disciplinary P. 25(d)(3); Alaska BAR R. 27(c)(4); CAL. Bus. \& Prof. CODE $\S 6049.1$ (b)(1) (West 2003); Colo. R. CIV. P. 251.21(d)(4); HAW. SuP. CT. R. 2.15(c)(4); ILL. SUP. CT. R. 763; IND. ADMISSION \& DisCIPLINE R. 23 § 28(c)(4); IOWA CT. R. 35.18(3)(c); Mich. Ct. R. 9.104(B); R. Discipline Miss. State BaR 13; NeV. SUP. CT. R. 114(4)(c); N.H. SUP. CT. R. 37(12)(d)(3); N.J. CT. R. 1:20-14(a)(4)(E); N.M. R. Gov. DISCIPLINE 17-210(C)(4); OHIO GOV. BAR R. V(11)(F)(4)(a)(ii); S.C. R. LAWYER DISCIPLINARY ENFORCEMENT 29(d)(4); S.D. CODIFIED LAWS $§ 16-19-74(3)$ (2011); TENN. SUP. CT. R. $9 \S 17.4(\mathrm{c})$; TEX. R. DisciplinaRY P. 9.04(D); UTAH R. JUD. ADMIN. 14522(d)(3); WASH. R. ENFORCEMENT LAWYER CONDUCT 9.2(e)(1)(D).

275 See, e.g., Ala. R. Disciplinary P. 25(d)(1); Alaska BAR R. 27(c)(1); CAL. Bus. \& Prof. CODE $\S$ 6049.1(b)(3); Colo. R. CIV. P. 251.21(d)(1); HAw. SuP. CT. R. 2.15(c)(1); Ill. SUP. CT. R. 763; IND. ADMISSION \& DISCIPLINE R. 23 \& 28(c)(1); IOWA CT. R. 35.18(3)(a); MICH. CT. R. 9.104(B); NEV. SUP. CT. R. 114(4)(a); N.H. SUP. CT. R. 37(12)(d)(1); N.J. CT. R. 1:20-14(a)(4)(D); N.M. R. GoV. DISCIPLINE 17-210(C)(1); S.C. R. LAWYER DISCIPLINARY ENFORCEMENT 29(d)(1); S.D. CODIFIED LAWS $§ 16-19-74(1)$; TENN. SUP. CT. R. 9 § 17.4(a); TEX. R. Disciplinary P. 9.04(A); UtaH R. JUd. AdMIN. 14-522(d)(1); Wash. R. ENFORCEMENT LAWYER CONDUCT 9.2(e)(1)(A).

276 See, e.g., Ala. R. DisciplinaRY P. 25(d)(2); Alaska Bar R. 27(c)(2); Cal. Bus. \& Prof. Code $\S 6049.1$ (b)(2); Colo. R. CIV. P. 251.21(d)(2); HaW. SuP. CT. R. 2.15 (c)(2); IND. ADMISSION \& DISCIPLINE R. $23 \S 28(\mathrm{c})(2)$; IOWA CT. R. 35.18(3)(b); NEV. SUP. CT. R. 114(4)(b); N.M. R. Gov. DISCIPLINE 17-210(C)(2); S.C. R. LAWYER DisCIPLINARY ENFORCEMENT R. 29(d)(2); S.D. CODIFIED LAWS $§ ~ 16-19-74(2)$; TENN. SUP. CT. R. $9 \S 17.4$; TEX. R. DISCIPLINARY P. 9.04(B); WASH. R. ENFORCEMENT LAWYER CONDUCT 9.2(e)(1)(B).

277 Of course cross-border cooperation can certainly be encouraged, as nothing prohibits a court or disciplinary authority in one state from informing disciplinary authorities in another state about actions they have taken against the home state's lawyer, but an enforceable requirement cannot. See generally supra note 228 (discussing courts informing out-of-state disciplinary authorities about sanctions they have imposed). Disciplinary authorities can also contact the ABA-run National Lawyer Regulatory Data Bank (Data Bank). See Ctr. for Prof'l Responsibility, National Lawyer Regulatory Data Bank, A.B.A., 


\section{B. Burden of Compliance on Reporting Entity and Others}

The burden of compliance in this area is minimal. Any individual lawyer whose conduct triggers the duty typically will have only a few incidents to report, at most. Under most systems, the amount of information the lawyer must compile and report is small. Usually a simple form or a brief letter notifying disciplinary authorities of the conviction or discipline imposed will suffice. ${ }^{278}$ At most, the lawyer may be required to provide a certified copy of the judgment or disciplinary order. ${ }^{279}$

Unlike the other reporting requirements discussed, where a burden is placed on a third party to report information pertaining to a lawyer, here the burden is internalized by the lawyer himself. That seems a fairer allocation of the reporting costs.

Depending on how these reporting requirements are drafted, however, compliance costs may be placed on others as well. If the lawyer need only notify state disciplinary authorities of the criminal conviction or disciplinary action, disciplinary authorities may need to expend effort to get an official copy of the underlying disposition. ${ }^{280}$ This is necessary to assure the veracity of the lawyer's self-report.

http://www.americanbar.org/groups/professional_responsibility/services/databank.html (last visited Mar. 9, 2012) (providing a general description of the Data Bank). Nevertheless, that requires an affirmative act by the disciplinary agencies; they are not informed automatically when lawyers they license are reported to the Data Bank. Further, the Data Bank has been criticized for being incomplete due in part to the fact that reporting disciplinary actions to it is voluntary. Brown, supra note 5, at 1607-08 (describing the Data Bank as "a wellintentioned gesture ... [with] serious weaknesses that render it ineffective" in part because "the ABA's Data Bank is ... functionally under-inclusive in that jurisdictions participate on a strictly voluntary basis"); Jennifer Carpenter \& Thomas Cluderay, Implications of Online Disciplinary Records: Balancing the Public's Interest in Openness with Attorneys' Concerns for Maintaining Flexible Self-Regulation, 22 GEO. J. LEGAL ETHICS 733, 746 (2009) (citing the voluntary nature of the reporting and concluding "the Data Bank lacks widespread state participation"). In addition, because it does not employ a universal identification number system, it is sometimes hard to identify whether a given lawyer, particularly one with a common name, has been reported. See, e.g., MCKAY REPORT, supra note 18, at 85-86 (noting name identification problems).

${ }^{278}$ For a sample of such forms that are used in California, see Report of Criminal Charges/Conviction, STATE BAR OF CAL., http://www.calbar.ca.gov/LinkClick.aspx?fileticket =beVMhofTCE8\%3d\&tabid=1147 (last visited Mar. 9, 2012). See also Reporting Form for Business and Professions Code Section 6068(o) Subsection (6), STATE BAR OF CAL., https://ethics.calbar.ca.gov/portals/9/documents/Other-Jurisdiction-Discipline-Form.pdf (last visited Mar. 9, 2012).

${ }^{279}$ See, e.g., IND. AdMISSION \& DisCIPLINE R. 11.1(a)(1); ME. BAR R. 7.3(d)(6); NEB. SUP. CT. R. § 3-326; N.D. R. LAWYER DisCIPLINE 4.4(A).

${ }^{280}$ Many states impose this retrieval duty on disciplinary officials or the clerk of the state supreme court. See, e.g., DEL. LAWYERS' R. DisCIPLINARY P. 18(a); HAW. SUP. R. CT. 2.15(a); IND. ADMISSION \& DISCIPLINE R. 28(a); LA. SUP. CT. R. XIX(21)(A); N.H. SUP. CT. R. 37(12)(a); OHIO Gov. BAR R. V(11)(F)(1); S.C. APP. CT. R. 413(29)(a); S.D. CODIFIED 
Whether requested by the self-reporting lawyer or the disciplinary authorities to whom the report is made, the body imposing the initial criminal or disciplinary disposition also will incur some costs in providing the information. That said, the acts of requesting official documentation and receiving it are largely ministerial and the costs associated are likely to be small.

Two modest suggestions might help limit those costs even further. First, the self-reporting lawyer should be required to include in the report the name of the tribunal and the case number or similar designation for the action involved. Second, to the extent these dispositions are made available online in easily searchable public databases, retrieval costs will be reduced.

\section{Potential Compliance Problems}

There are three classes of compliance problems I foresee. The first is that lawyers may not know of the reporting requirements. ${ }^{281}$ While lawyers should be aware of both the disciplinary rules and the court rules of the jurisdictions in which they practice, that may not be the case as a practical matter. ${ }^{282}$ To the extent the state has a set of rules of professional conduct, particularly one with a duty to report the misconduct of others, many lawyers will assume that such a document defines the extent of their responsibilities. They may assume that, in the disciplinary area, court rules govern more peripheral matters like registration requirements, bar fees, continuing legal education (CLE) obligations, etc. In most states, however, the self-reporting requirements are in the latter, not the former. ${ }^{283}$ If we truly want self-reporting to work, adequate notice is the minimum requirement.

To the extent the information to be reported flows from a court determination, like the conviction of a crime or the imposition of court sanctions, the rendering court might alert the lawyer to the self-reporting

LAWS § 16-19-71; TENN. SUP. CT. R. 9 §17.1; UTAH R. JUD. AdMIN. 14-522(a); VT. SuP. CT. ADMIN. ORDER 9, R. 20(A).

281 See, e.g., CCFAJ REPORT, supra note 14, at 79 (finding the California self-reporting provisions "widely ignored" and attributing that in part to attorneys being "simply unaware" of the requirement). But cf. In re Sullivan, 5 Cal. State Bar Ct. Rptr. 189, 195 (Review Dep't 2010) (rejecting lawyer's ignorance as an excuse for not reporting a criminal charge and conviction since the statutory directives to report are "clear"). Confusion over whether to report when the court also has a duty to do so may also contribute in part. See supra text accompanying note 183. The number of self-reports in California per year from 2007 to 2010 ranged from 94 to 165. 2010 CALIFORNIA ATTORNEY DISCIPLINE REPORT, supra note 50 , at 44 .

282 See Dietrich, supra note 238, at 21 (describing Wisconsin's self-reporting provision for criminal convictions as "a lesser-known provision").

$283 \mathrm{~A}$ few states do place this reporting requirement in their professional conduct rules. See, e.g., N.C. R. PROF. ConduCt 8.3(d); VA. R. Prof. ConduCt 8.3(e). 
obligation. ${ }^{284}$ To the extent reportable disciplinary sanctions are handed down by another body, that body could do likewise.

Another way to police this matter, if time is not of the essence, is to require lawyers to disclose certain misconduct when they file their annual registration statements with the state judicial system. ${ }^{285}$ This already is the practice in some, but not all, states. ${ }^{286}$ Here the lawyer can be alerted about the acts that must be reported by requiring the lawyer to affirmatively state whether or not triggering events occurred during the time since dues were last paid, and requiring further information if they have.

Assuming adequate notice can be provided, attention also must be given to how the rule is drafted. Again, as in other areas, the clearer the rule, the greater the chance for compliance. With respect to the reporting of criminal convictions, I would require reporting convictions of any crime, except traffic offenses that do not involve the use of alcohol or a controlled substance. ${ }^{287}$ Such a standard eliminates three forms of potential confusion. First, it eliminates the chance, however so slight, that the lawyer will misunderstand the categorization of the criminal offense of which he is convicted-a problem that could arise if reporting were limited to a single class of crimes, such as felonies. Second, it eliminates most problems of a mismatch between jurisdictions about

${ }^{284}$ It is common in California for courts imposing reportable sanctions to cite the offending attorneys to the statutory self-reporting provision and order them to comply with it. See, e.g., Mesbah v. Fallahi, No. C060689, 2010 WL 2725587, at *6 (Cal. Ct. App. July 12,2010 ) (citing to self-reporting duty and ordering reporting of an almost $\$ 20,000$ sanction for pursuing a frivolous appeal); Emercon Constr., Inc. v. Butterfield, No. G041033, 2010 WL 1952736, at*17 (Cal. Ct. App. May 17, 2010) (citing to self-reporting duty and ordering reporting of $\$ 25,000$ sanction for flagrant failure to follow the appellate rules).

285 See NATIONAL ACTION PlaN, supra note 18, at 36 (endorsement by the Conference of Chief Justices of such reporting on annual registration statements).

${ }^{286}$ In an informal telephone survey in March 2010 conducted by my research assistant, Danielle Gadomski, roughly a quarter of the fifty states and the District of Columbia imposed such a requirement or its equivalent. See Danielle Gadomski, Calls re: Annual Registration (Mar. 23, 2010) (unpublished survey notes) (on file with author). For a sample form, see Bd. of Overseers of the Bar, Maine Annual Registration Statement-Fiscal Year 2010 (questions 6 and 8).

${ }^{287}$ Given the well-documented problems that alcohol and substance abuse cause many in the legal profession, and the significant interrelationship between such problems and disciplinary violations, it is appropriate to track even traffic offenses that provide some indicia of a potential abuse problem. See Laura Rothstein, Law Students and Lawyers with Mental Health and Substance Abuse Problems: Protecting the Public and the Individual, 69 U. PITT. L. REV. 531, 532 \& n.3 (2008). While all traffic offenses are relevant information for disciplinary authorities, since a significant pattern of such offenses may show disrespect for the law warranting discipline, see In re Witt, 452 S.E.2d 507, 508 (Ga. 1995) (per curiam) (imposing a six-month suspension for lack of proof of insurance, improper license plates, and driving on a suspended license after a history of alcohol-related driving arrests); cf. In re Acton, 902 N.E.2d 966, 969 (Ohio 2009) (denying bar admission in part because of a "continued pattern of disregard of the traffic laws"), this extreme situation is rare and probably does not warrant the costs involved in reporting and tracking such behavior in the disciplinary system. 
how to label a certain crime (e.g., as a felony or a misdemeanor), and which jurisdiction's labeling should control for purposes of the reporting duty. For example, assume $X$ is treated as a misdemeanor in some jurisdictions and as a felony in others. If a lawyer is licensed in a state that requires the reporting only of felony convictions and the lawyer is convicted of a crime in another jurisdiction that treats the crime differently from its own, the lawyer may be confused as to how to characterize the crime for reporting purposes. ${ }^{288}$ An allcrimes approach minimizes the chance for confusion.

As to the definition of "conviction," I would utilize a broad definition such as that employed in Nevada, which provides that the term "shall include a plea of guilty or nolo contendere, a plea under North Carolina v. Alford, 400 U.S. 25 (1970), or a guilty verdict following either a bench or a jury trial."289 This will cut off any argument by a lawyer who fails to self-report that the term "conviction" is meant to have some narrower definition excluding some of the foregoing.

With respect to reporting disciplinary activity, I would require the reporting of all disciplinary sanctions imposed, whether public or private, by any body, for violation of the rules of professional conduct. The rule is clear, and if small but cumulative misconduct occurs, that may be a call to action. Drafters also should consider requiring self-reporting of nondisciplinary judicial sanctions imposed and other relevant matters as California has done. ${ }^{290}$

The impact of appeal or other postconviction relief also should be treated. Confusion has arisen where it has not. ${ }^{291}$ As in other reporting requirements, I

288 That this problem can arise is recognized by the rules of some states that directly address this possible mismatch. See, e.g., MD. R. 16-701(k) (defining, in part, "[s]erious crime" that must be reported as a felony under Maryland law as "a crime in another state or under federal law that would have been a felony under Maryland law had the crime been committed in Maryland"); VA. R. PROF. CONDUCT $8.3 \mathrm{cmt} .6$ (providing, with respect to the requirement to self-report felony convictions, that the classification of the crime by the rendering jurisdiction controls and that as a result, "it is possible that an offense in another jurisdiction may be a misdemeanor crime for which there is no duty to self-report, even though under Virginia law the offense is a felony"); $c f$. CONN. R. SUPER. CT. $§ 2-41$ (c) (defining "serious crime" in part as "any felony or any larceny as defined in the jurisdiction in which the attorney was convicted"). The self-reporting requirements in most states, however, are silent on this matter.

289 NeV. SUP. CT. R. $111(1)$.

${ }^{290}$ CAL. BUS. \& Prof. CODE $\S 6068(0)$ (West 2003 \& Supp. 2012) (listing seven categories of actions requiring attorney self-reporting).

291 See generally, e.g., In re Respondent Y, 3 Cal. State Bar Ct. Rptr. 862 (Review Dep't 1998). In that case, under California law, the lawyer was required to report to disciplinary authorities that certain judicial sanctions had been "levied against him" within thirty days of learning that fact. Id. at $865 \mathrm{n} .2,866$. The attorney did report, but only after his appeal of those sanctions concluded. Id. at 865 . The hearing judge found that timing appropriate, relying in part on the theory that the appellate court, by its actions, should decide what judicial sanctions warranted bar attention. Id. at 866 . The respondent also argued that waiting until after appeal would protect the bar from being overwhelmed with reports, many involving sanctions that might be overtumed on appeal. Id. at 867. The State Bar Court 
would not permit appeal or other collateral attacks to postpone the duty to report. 292

The information that must be reported also should be clear. Most of the provisions in this area are silent on what information must be contained in a required report. Where the lawyer is required to provide a certified copy of the criminal conviction or the disciplinary sanction, all the necessary information may be contained there. But where, as in most states, that is not the case, the rule should detail what would be required. ${ }^{293}$

A set time to act should be given rather than using an ambiguous term like "promptly" to define the time in which the lawyer must act. The norm is thirty days, which seems a sensible time period. ${ }^{294}$ Some states impose time periods as low as five days in which to make the report. ${ }^{295}$ Given the amount of turmoil a lawyer experiences upon being disciplined or convicted of a crime, such short periods seem unrealistic.

Finally, absent some inducement, it is likely that many lawyers will flout their reporting duties. ${ }^{296}$ Reporting will likely cause them harm as it may lead to interim suspension or reciprocal discipline in jurisdictions in which they presently are allowed to practice. While many lawyers will do their duty and report, it is not unreasonable to suspect that many will not. ${ }^{297}$ After all, these are lawyers who already have forsaken their duty by committing a crime, an ethical violation, or both. 298

disagreed, noting inter alia that: (1), this is just a report, not an act requiring automatic sanction, so there is no harm in telling the bar; and (2), the language of the statute and the different treatment in different sections as to finality suggest that the lawyer's knowledge of the imposition of the initial entrance of the sanction is the triggering event. Id.

${ }^{292}$ See supra text accompanying note 194.

${ }^{293}$ For sample self-reporting forms, see Forms, STATE BAR OF CAL., http://www.calbar.ca.gov/Attorneys/Forms.aspx (last visited Mar. 9, 2012).

294 See supra note 259.

295 WIS. SUP. CT. R. $21.15(5)$.

${ }^{296}$ See, e.g., CCFAJ REPORT, supra note 14, at 79 (promoting the prospect of discipline for failure to self-report as a possible cure for chronic underreporting by California lawyers). The likelihood that inducements might spur reporting is reinforced when the chance of apprehension for nonreporting is high. See Jodi L. Short \& Michael W. Toffel, Coerced Confessions: Self-Policing in the Shadow of the Regulator, 24 J.L. ECON. \& ORG. 45, 47-48 (2008) (citing "an economic model that suggests that violators with a greater risk of apprehension are more likely to self-disclose their wrongdoing"). Here, parallel reporting of a lawyer's conduct by other entities, such as courts with regards to conviction of a crime, increases the likelihood that a lawyer's failure to report will be apparent.

297 See, e.g., FELLMETH, supra note 13, at 58 (finding "very little compliance" with selfreporting requirements in California).

298 In discussing the broader duty to self-report imposed in some states, one author commented:

It may not be reasonable to expect lawyers to turn themselves in for their own ethical violations. The substantial adverse social and economic consequences which flow from any form of public discipline is a significant disincentive for a lawyer to seek disciplinary inquiry of his or her own conduct. Even if disciplinary proceedings result in 
Two sorts of inducements are possible. 299 To the extent the attorneys do report their misconduct when required, it reflects a certain cooperation with the system that may be credited as a mitigating factor to be considered in any disciplinary sanction imposed. ${ }^{300}$ To the extent the lawyers do not report, it provides another violation on which to attach disciplinary sanctions ${ }^{301}$ or at least can be treated as an aggravating factor when the underlying conduct is discovered and made the basis for discipline. ${ }^{302}$ As one court remarked, additional punishment for failure to report where required is warranted as such conduct undermines "the integrity of the bar" and brings the public perception of the profession into "disrepute." 303

In instances where lawyers with a reporting duty are represented by counsel who specialize in the law of lawyering and the inducements to report are significant, self-reporting may rise significantly. The reporting requirement will be known, and following it will be rewarded.

\section{Indirect Consequences}

To the extent self-reporting turns on the seriousness of the crime committed, or the nature of the disciplinary sanction imposed, the reporting scheme may affect the bargaining power of the participants in those settings. For example, a lawyer-defendant might be more likely to take a plea bargain

dismissal or private discipline, the lawyer may expend significant time and emotional resources before they are concluded.

James E. Mitchem, The Lawyer's Duty to Report Ethical Violations, 18 Colo. Law. 1915, $1916(1989)$.

${ }^{299}$ Literature suggests that "people respond more strongly to incentives than penalties."

Yuval Feldman \& Orly Lobel, The Incentives Matrix: The Comparative Effectiveness of Rewards, Liabilities, Duties, and Protections for Reporting Illegality, 88 TEX. L. REV. 1151, 1181 (2010). The inducements suggested here include both.

${ }^{300}$ It is my understanding that Ohio treats compliance with the duty to report criminal convictions in this manner. Interview with Jonathan E. Coughlan, Disciplinary Counsel, Supreme Court of Ohio, in Columbus, Ohio (June 16, 2011). However, not all jurisdictions do so. See, e.g., In re Duxbury, 4 Cal. State Bar Ct. Rptr. 61, 65 n.3 (Review Dep't 1999) (rejecting treating self-reporting of a criminal violation as a mitigating factor because attorney already had a required duty to report).

301 See, e.g., CAL. Bus. \& PROF. CODE $\S 6068(0)(10)$ (West 2003 \& Supp. 2012); IDAHO BAR COMM'N R. 512(a); N.C. BAR R. ch. 1B $\S \S .0100-.0116$; OKLA. STAT. ANN. tit. 5, ch. 1, app. 1-A, r. 7.7 (West 2011); WIS. SUP. CT. R. 21.15(4). At times, failure to self-report can be the grounds for discipline even if the underlying conduct to be reported would not. See, e.g., Scott Drexel, Lawyers Can Avoid Discipline by Reporting Adverse Actions or Events, CAL. B.J., Mar. 2008, at 7, 7 (comments by the then-chief trial counsel of the State Bar of California noting such cases in California). In contrast, to the extent this adds an additional violation to others it also becomes but one of multiple acts of misconduct, and such a pattern often is treated as an aggravating factor in assessing the sanction to be imposed. See, e.g., In re Riordan, 5 Cal. State Bar Ct. Rptr. 41, 48 (Review Dep't 2007).

302 See, e.g., W. VA. R. LAWYER DISCIPLINARY P. 3.18(a).

${ }^{303}$ See, e.g., Office of Disciplinary Counsel v. Casety, 512 A.2d 607, 611 (Pa. 1986). 
from a prosecutor if it would take a reportable offense off the table and allow the lawyer to plead to a nonreportable offense. There would be pressure to take the plea, even if the lawyer might be found not guilty should the action proceed to trial. Similar pressure might arise in the disciplinary setting if only certain levels of sanction warrant reporting. Lawyers might be willing to stipulate to certain violations in the hope of a lenient sanction for which reporting is not required. It is hard to assess how significant a benefit it is to lawyers to avoid the reporting of this information to disciplinary authorities where they are licensed, but given the near automatic imposition of interim suspension and reciprocal discipline for criminal convictions and disciplinary sanctions respectively, the benefit may be substantial. ${ }^{304}$

\section{E. Extending the Self-Reporting Regime to Other Areas}

As mentioned at the outset of this section, California not only requires lawyers to self-report criminal and disciplinary sanctions imposed upon them, it also requires reporting the imposition of most court-imposed sanctions and certain lawsuits in which the lawyer's professional behavior is called into question. ${ }^{305}$ With respect to court-ordered sanctions, a lawyer must report " $[t]$ he imposition of judicial sanctions against the attorney, except for sanctions for failure to make discovery or monetary sanctions of less than one thousand dollars $(\$ 1,000) . " 306$ In terms of reporting lawsuits in which the lawyer's professional behavior is called into question, the statute requires the lawyer to report:

- "The filing of three or more lawsuits in a 12-month period against the attorney for malpractice or other wrongful conduct committed in a professional capacity"; 307

- "The entry of judgment against the attorney in a civil action for fraud, misrepresentation, breach of ' fiduciary duty, or gross negligence committed in a professional capacity"; 308 and

- "Reversal of judgment in a proceeding based in whole or in part upon misconduct, grossly incompetent representation, or willful misrepresentation by an attorney." 309

${ }^{304}$ See supra notes 263, 270 and accompanying text. For a similar discussion in the context of court reporting, see supra text accompanying note 202.

305 CAL. BUS. \& PROF. CODE $§ 6068(0)$.

${ }^{306}$ Id. $\S$ 6068(o)(3); see, e.g., Riordan, 5 Cal. State Bar Ct. Rptr. at 47-48 (sanctioning lawyer for failure to follow this provision).

${ }^{307}$ CAL. BUS. \& PROF. CODE $\S 6068(0)(1)$.

308 Id. $\S 6068(0)(2)$. See generally In re Kittrell, 4 Cal. State Bar. Ct. Rptr. 195 (Review Dep't 2000) (finding attorney violated this provision).

${ }^{309}$ CAL. BuS. \& Prof. CODE $§ 6068(0)(7)$; see Hernandez v. Paicius, 134 Cal. Rptr. 2d 756, 767 (Ct. App. 2003) (ordering lawyer to report pursuant to this provision). 
An additional reporting requirement applies to the extent a California lawyer does not carry malpractice insurance. 310 The lawyer must "send a complete written report to the State Bar as to any settlement, judgment, or arbitration award" 311 in "[e]very claim or action for damages against [the lawyer] for fraud, misrepresentation, breach of fiduciary duty, or negligence committed in a professional capacity." 312

If disciplinary authorities find this or other information useful, they could expand the self-reporting duty accordingly.

\section{F. Recommendation}

Self-reporting is a low-cost way to potentially get important information into the hands of disciplinary authorities. This is particularly true in an era of increased multijurisdictional practice. As lawyers licensed in one state practice in others, the chance of out-of-state sanctions, be they criminal or disciplinary, increases. Those sanctions are less likely to come to the attention of home state disciplinary authorities than sanctions imposed within the home jurisdiction. ${ }^{313}$

That said, there are still substantial compliance problems. Earlier in this section I identified some ways to increase compliance, ${ }^{314}$ but it is likely that significant underreporting will remain. If it is true that lawyers often will not self-report, is there any justification for imposing the duty? Several justifications exist.

First, as mentioned above, lawyer self-reporting may, at a practical level, offer the most likely avenue to bring out-of-state sanctions to the attention of licensing state's disciplinary authorities. Here, underreporting is better than no reporting at all.

To the extent the information to be reported by the lawyer also is to be reported by other actors, such as malpractice insurers or the courts, the latter of which often occurs in-state, the duty acts as a safety net. If multiple reporting is required, information may get to disciplinary authorities even when some actors fail to fulfill their reporting duty.

On a more cynical level, if failing to report is itself treated as a disciplinable offense or an aggravating factor, ${ }^{315}$ this may be used as an easy handle to ratchet-up the discipline when the lawyer is caught in the web by reporting of

${ }^{310}$ CAL. BUS. \& PROF. CODE $\$ 6086.8$ (c) (West 2003). The pros and cons of reporting malpractice information to disciplinary authorities, whether by malpractice insurers or by uninsured lawyers, is discussed at supra Part III.

311 CAL. BUS. \& PROF. CODE $§ 6086.8(\mathrm{c})$.

312 Id. $\S 6086.8$ (b).

313 See supra text accompanying note 277; see also Jack P. Sahl, Foreword: The New Era-Quo Vadis?, 43 AKRON L. REV. 641, 674 (2010) (noting the increase in multijurisdictional practice and the "need for a more unified and collaborative approach to professional regulation" in an "increasingly fragmented regulatory framework").

314 See supra text accompanying notes $299-303$.

315 See supra text accompanying notes $301-02$. 
another. One might argue that punishment here is analogous to the treatment we give noncooperation in disciplinary investigations by lawyers subject to those investigations. On the other hand, it does seem a bit like a "gotcha" offense not closely tied to the proper regulation of lawyer conduct. If this were the only justification for a self-reporting requirement, I would hesitate to impose it.

\section{Potential Systemic Problems Flowing From an Automatic REPORTING REGIME}

In previous Parts, I addressed the problems that each particular reporting requirement might engender, assessed their severity, and proposed ways to limit them. In this Part, I address potential systemic problems with an automatic reporting regime. The three principal concerns that arise are fear of misuse of the information by disciplinary authorities, the possibility that the amount of information reported might overload the system, and the strain on resources additional reporting may engender.

\section{A. Information and the Overzealous Disciplinary Counsel}

To the public, the idea of an overly zealous disciplinary counsel seems farfetched. The public perception of the lawyer disciplinary process is that it is far too lax, not too aggressive. ${ }^{316}$ If you asked those involved in defending lawyers in disciplinary actions, they might well have a different view. 317

If one subscribes to the latter view, then these proposals, taken as a whole, may seem particularly threatening. Under the present system, disciplinary authorities often have limited information about the conduct of a particular lawyer, which, in turn, constrains the ability of the authorities to bring actions

316 See, e.g., DEBORAH L. RHODE, IN THE INTERESTS OF JUSTICE: REFORMING THE LEGAL PROFESSION 158 (2000). Help Abolish Legal Tyranny (HALT), a well-known advocacy group critical of lawyer self-regulation, describes the disciplinary systems in the United States as "badly broken and in need of urgent reform." Lawyer Discipline, HALT, http://www.halt.org/what-we-do-for-you/hold-lawyers-accountable/lawyer-discipline (last visited Apr. 14, 2012); see also 2006 Lawyer Discipline Report Card, HALT, http://www.halt.org/news-a-publications/report-cards/2006-lawyer-discipline-report-card (last visited Apr. 14, 2012) (finding, in its 2006 rating of state disciplinary systems, only three states with a grade above a "C").

${ }^{317}$ See, e.g., Allison Lomas, State Bar's Discipline Process Criticized at Hearing, Metropolitan News-ENTERPRISE (L.A.), Dec. 11, 2002, at 1 (reporting attorney defense counsels" criticisms of those prosecuting disciplinary cases in California as "overzealous," "punitive against lawyers," and "overly adversarial"); Howard Mintz, State Bar: No Pressure in Firing, SAN JOSE MERCURY NEWS, June 12, 2009, at 4B (reporting that fired California head disciplinary prosecutor "has drawn complaints from lawyers who represent attorneys facing discipline charges for what they say is a heavy-handed approach, as well as from the state's district attorneys, who argue he's been overzealous in going after prosecutors for ethical violations"). 
against those lawyers. ${ }^{318}$ With more information at their disposal, more cases that can be "made" will become apparent, and actions may be brought against those lawyers.

On one hand, that is exactly what the proposal is intended to promote. The goal is to create a greater flow of information to disciplinary authorities. At times, one piece of information will be enough to trigger further investigation. In others, it will be the cumulative effect of a number of actions, no one of which, standing alone, would warrant intervention. In the proposed model, if the information warrants, disciplinary authorities will pursue remediation in some circumstances and discipline in others.

On the other hand, the proposal may not work as intended. A disciplinary counsel with an agenda might now have enough information to bring at least a colorable action against an attorney that otherwise would not even pass the laugh test. Whether driven by personal animus or public pressure, prosecutors can run amok. 319

Even without an improper motive, it is possible that disciplinary counsel may overvalue the cumulative effect of the information acquired. There may be a full-file phenomenon-a subconscious tendency to think that if the file looks thick, there must be something there.

That said, instances of proven abuse of the disciplinary process by disciplinary counsel are rare. And while it is possible that disciplinary authorities may overvalue files with multiple reports, it is unlikely that the authorities would be misled into utilizing scarce resources to prosecute such cases in lieu of pursuing those cases that seem on their face to involve serious misconduct.

\section{B. Automatic Reporting and System Overload}

Even if the reported information is potentially useful, that potential can be realized only if disciplinary authorities have the resources and ability to manage the data received. In analyzing this aspect of the problem, two principal issues emerge-the reporting volume and the state's processing capabilities.

318 See supra text accompanying notes $1-15$.

319 See Janet Elliott, Victory Bittersweet for Bar's Target, TEX. LAw., Oct. 24, 1994, at 5 (describing that lawyer who successfully fought off disciplinary charges brought against her by disciplinary counsel 'believes she was the victim of a 'witch hunt' designed to thwart her ambition to run for a judicial seat"); Mark Hansen, Nevada Supreme Court Investigated: Ethics Experts Criticize Its Decision to Stay Disciplinary Probe of Reno Judge, A.B.A. J., June 1994, at 26, 26 (discussing Nevada Supreme Court's stay of disciplinary charges against a judge who claimed "that the Nevada Commission on Judicial Discipline [was] engaged in a 'witch hunt' against him"); Emily Heller, Bar Rule Would Shield Lawyers: Critics Decry Secrecy Designed to Prevent Self-Incrimination, DAILY REP. (Fulton Cnty., Ga.), Mar. 28, 1996, at 1, 2-3 (reporting that critics on the Georgia Bar Board of Governors believe that State Bar's general counsel "orchestrates witch hunts against lawyers"). 
It is difficult to determine with precision how much new reporting an automatic reporting regime would generate in any particular state. California, which has a large lawyer population ${ }^{320}$ and the most extensive system of selfreporting and automatic reporting by others, ${ }^{321}$ provides some indication of the high side of reporting that such a system might generate. In California the number of mandatory reports received from all sources yearly has ranged from 2180 to 3407 during the period from 2005 to 2009.322 During that period, the number of those reports that led to investigations ranged from 333 to $602 .{ }^{323}$

One should not overgeneralize from this, however. First, the extent of reporting turns on how the reporting mandate is constructed. As illustrated above, a claims-made reporting system for lawyer malpractice, for example, would generate many more reports than a claims-paid reporting system. ${ }^{324}$ Second, as discussed elsewhere in this piece, compliance issues also affect the numbers. ${ }^{325}$ In California, compliance problems have been identified with respect to certain aspects of the reporting system, so its numbers are undoubtedly low. ${ }^{326} \mathrm{Up}$ to a point, the more effort that is placed on securing compliance with the reporting duties, whether by education, clearer rules, or penalties for failure to follow them, the more reporting will occur.

With respect to processing the data, the ability of a state to handle the data turns on the system the state has in place for doing so. If lawyer disciplinary records in a state are kept electronically, in a centralized fashion, the record building and retrieval contemplated by automatic reporting can most easily occur. If the records are not kept electronically, and if data are kept by locality, rather than statewide, the input and retrieval costs likely will be higher and some capturing of aggregative effects will be lost.

\section{Automatic Reporting and Resource Constraints}

Implementation of an automatic reporting requirement will create some additional costs for disciplinary agencies. Each new report will need to be handled. The associated costs will vary depending on how the data are used. Simply adding a report to a file would entail little additional cost; fully

${ }^{320}$ In 2011 , there were 157,388 lawyers that were active status resident in California, second only to New York. Mkt. Research Dep't, National Lawyer Population by State, A.B.A., http://www.americanbar.org/content/dam/aba/migrated/marketresearch/Public Documents/2011 national_lawyer_by_state.authcheckdam.pdf (last visited Mar. 9, 2012).

${ }^{321}$ See supra Parts II-V.

3222009 CALIFORNIA DISCIPLINE SYSTEM REPORT, supra note 50, at 6. It should be noted that some of those reports will be duplicative in instances where both the court and the attorney have the duty to report the same conduct.

${ }^{323} I d$. In 2010, that number went up dramatically to 1093. 2010 CALIFORNIA ATTORNEY DISCIPLINE REPORT, supra note 50, at 44.

324 See supra text accompanying note 96.

325 See supra Parts II.B, III.B, IV.B, V.B.

${ }^{326}$ See supra note 109 and text accompanying note 171 . 
evaluating each will require much more. If more cases are prosecuted as a result of this information, costs will increase yet again.

In a world of unlimited resources, we might imagine that every report would be reviewed with care and that follow-up for additional information would be common. On the other hand, given resource limitations, some shortcuts might be used. There may be certain classes of information that would be presumptively reviewed with care-reports of lawyer felony convictions, for example. Whereas other information, such as malpractice claims settled for a small amount, might simply be put into the attorney's file. Such logged information could be used in the future in one of two ways. One might set up a system that sets off a red flag when a certain amount of reportable conduct is in an attorney's file in a specified time span. For example, in the Ohio medical malpractice statutes, malpractice claims for which monetary compensation in excess of $\$ 25,000$ is paid must be reported to the state medical board. ${ }^{327}$ If there are three such reports within a five-year period involving negligent conduct, the Board must undertake an investigation. ${ }^{328}$ Under this approach, the file would be flagged when this threshold is reached. Alternatively, the data might just reside in an attorney's records until a particular triggering act occurred, such as a colorable claim of misconduct warranting further investigation, but then would be there as background information in assessing the lawyer's conduct more broadly.

In a time of fiscal restraint, a question arises as to how disciplinary authorities can handle these additional costs. If automatic reporting helps uncover a significant number of cases for which remediation or disciplinary action is warranted, funding authorities may conclude that such additional money would be well spent. If additional funding for such a project cannot be obtained, disciplinary counsel may decide to simply put the information in a lawyer's file, where it will reside until some other action triggers an investigation or the number of filed entries on a lawyer is sufficient to red flag the file for further investigation. This may significantly lower the costs of automatic reporting for disciplinary authorities. Finally, just as now, disciplinary authorities exercise prosecutorial discretion in deciding which cases to pursue. The additional information automatic reporting generates simply helps inform that prosecutorial discretion. A reporting scheme that is not automatic puts some of that discretion into the hands of others by their choices as to whether to report. Arguably, the discretion to act should reside with disciplinary counsel who can better exercise that discretion with fuller information. 329

327 OHIO REV. CODE ANN. $\$ 4731.224$ (D) (West Supp. 2011).

${ }^{328}$ Id. $\S 4731.224(\mathrm{E})$; see also Brown, supra note 5, at 1611 (suggesting the creation of a national litigation misconduct database in which investigation would be required if a lawyer were reported to this database in excess of three times during a four-year period).

${ }^{329}$ See, e.g., CCFAJ REPORT, supra note 14, at 73 (noting in a discussion of automatic reporting by California courts that "the State Bar is the most appropriate forum to exercise 


\section{CONCLUSION}

An effective lawyer disciplinary system is essential to protect the public and to maintain the integrity of the profession. To be effective, however, lawyer misconduct must come to the attention of disciplinary authorities.

It is widely agreed that the present system, which primarily relies on reporting by lawyers and judges, to the extent required by their respective ethics codes, and laypersons, leaves much potential misconduct unreported. A system requiring automatic reporting of certain events can help close that reporting gap.

The system I envision places reporting duties on third parties providing services to lawyers, the courts, and individual lawyers already convicted of a crime or sanctioned for unethical conduct. Some of these duties, like overdraft notification by banks, or self-reporting by lawyers, already are well-established, although not universally so. Others, like imposing a reporting duty on malpractice insurers or courts, have not been adopted widely. None have been systematically studied.

Each of these devices has its own costs, benefits, and unintended consequences. Each can be implemented in a variety of ways. This Article catalogs and critiques those costs, benefits, and consequences, and provides recommendations for the implementation of these devices.

In the end, an automatic reporting system of the kind I envision would improve the disciplinary process. At times, the conduct reported, standing alone, would warrant discipline. Even when it does not, the information still would be useful to disciplinary authorities. A pattern of minor misconduct may, in the aggregate, warrant discipline, but instances of minor misconduct often are not reported to disciplinary authorities under the present system. An automatic reporting system can be structured to bring more of that conduct to the attention of disciplinary authorities. Further, even if these acts do not rise to the level of a disciplinary offense, they still may reflect deficiencies in a lawyer's law office management, trust accounting, and the like. In those instances disciplinary authorities could offer remedial training to help solve incipient problems before serious misconduct occurs. In short, automatic reporting would improve the quality of lawyer disciplinary systems, to the benefit of the public and profession alike.

discretion, and the exercise of that discretion must be informed by a cumulative track record" including required reports from the courts). 